SAND94-2575

Unlimited Release

Printed October 1994
Distribution

Category UC-700

\title{
INDEPENDENT TECHNICAL REVIEW OF THE \\ SANDIA NATIONAL LABORATORIES HUMAN RESOURCES PROGRAM
}

\author{
Conducted By The \\ Capability Assessment Department \\ Sandia National Laboratories \\ Albuquerque, NM 87185-1003
}

\begin{abstract}
The architecture and cost of the Sandia HR Program are fundamentally inconsistent with the commercial business standard. Breakthrough change is required to resolve the architecture and cost issues; minor fixes won't do. Substantial barriers are in the path to this breakthrough change. DOE oversight and requirements do not appear to be driving or limiting $H R$ improvements. Major HR barriers are self imposed.

As a solid foundation for the new architecture, the HR management team needs to begin building a valued-partner customer relationship with the Divisions. To initiate this relationship, solution oriented HR generalists should be placed in the Divisions. The generalists must be backed by a HR Program staff of solution-oriented specialists.

To improve delivery and lower costs, the architecture of the HR Program must be reevaluated and potentially redesigned based on the concept of a business-requirements core set of policies, products, and services. A menu of other optional products and services should be offered to each Division on a cost recovery basis. Cost reduction driven processes and technology must be used to equip and enable the Divisions to flexibly meet their business and people resource needs. The HR Program infrastructure should be consolidated to achieve these purposes.
\end{abstract}




\section{DISCLAIMER}

This report was prepared as an account of work sponsored by an agency of the United States Government. Neither the United States Government nor any agency thereof, nor any of their employees, make any warranty, express or implied, or assumes any legal liability or responsibility for the accuracy, completeness, or usefulness of any information, apparatus, product, or process disclosed, or represents that its use would not infringe privately owned rights. Reference herein to any specific commercial product, process, or service by trade name, trademark, manufacturer, or otherwise does not necessarily constitute or imply its endorsement, recommendation, or favoring by the United States Government or any agency thereof. The views and opinions of authors expressed herein do not necessarily state or reflect those of the United States Government or any agency thereof. 


\title{
DISCLAIMER
}

\begin{abstract}
Portions of this document may be illegible in electronic image products. Images are produced from the best available original document.
\end{abstract}




\section{TABLE OF CONTENTS}

1. Table of Contents

2. Preface

3. Executive Summary

4. $\quad$ Red Team Process

5. Commercial Standard

5.1 Introduction

5.2 Line Manager Need

5.3 Enable the Money Makers

5.4 Role in Organizational Change

5.5 Partner with Line Managers

5.6 Lean and Agile

5.7 Work Force Attributes

6. Recommendations

6.1 Introduction

6.2 Assumptions and Definitions

6.3 Redesigned Architecture

6.3.1 Build a Valued-Partner Customer Relationship by Supporting the Divisions with Solution Oriented HR Generalists; Support the Generalists with a Staff of Specialists

6.3.2 Conduct a Clean Slate Reevaluation and Potentially a Redesign of the Core HR Policies, Products and Services, Based on Sandia's 
Business Requirements; Negotiate Optional Products and Services with Each Division

6.3.3 Enable and Equip the Divisions to Flexibly Meet Their Business and People Resource Needs with Cost Reduction Driven Process and Technology

6.4 Resource Management

6.4.1 Resource Plan

6.4.2 Resource Direction

6.4.3 Resource Model

6.5 Total Compensation

6.5.1 Broad Banding/Job Classification vs. Job Evaluation

6.5.2 Support to Performance Management Process Implementation

6.5.3 Linkage of Non-Base Pay to Achievement of Enterprise Direction

6.5.4 Benefits Design

6.6 Organizational and Individual Effectiveness (O\&IE)

6.7 Employee and Management Relations

6.7.1 Develop Clearly Defined Roles, HR Responsibilities, and HR Accountabilities for Line Managers

6.7.2 Create a Consulting Organization (HR Operations)

6.7.3 Acquire Additional Strategic Direction from Senior Management to Enhance the Effectiveness of Labor Relations 
$6.8 \quad$ Infrastructure

6.8.1 Introduction

6.8.2 Infrastructure Recommendations

6.8.3 Benefits

7. Next Steps

7.1 Define and Adopt the Path Forward

7.2 Recommend Path Forward to the Reengineering Steering Committee

7.3 Add Additional Expertise to the HR LPR Team

7.4 Develop an Internal Communications Plan

7.5 Adding a "Breakthrough" Manager

8. General Diagnosis

8.1 Introduction

8.2 Current State

8.3 Change is Needed

8.4 Institutional Barriers

8.5 Assets Foundation for Change

8.6 Program Barriers

\section{APPENDICES}

A. Charter and Review Plan

B. Information Sources 


\section{B.1 Documents}

B.2 Interviews/Meetings

C. Activity Diagnosis

(Assets, Barriers, Strengths, Weaknesses)

C.1 Staffing and Recruiting

C.2 Job Evaluation and Compensation

C.3 Diversity

C.4 Benefits and Health

C.5 Training, Organizational Development

C.6 Educational Outreach

C.7 Performance Assessment and Management

C.8 Employee/Labor Relations

C.9 EEO/AA

D. Commercial Business Examples of Core-Optional Analysis

D.1 Westinghouse Human Resources Survey

D.2 XEROX

D.3 IBM

E. Team Members

E.1 ITR Team Members

E.2 ITR Team Credentials

F. List of Acronyms 


\section{PREFACE}

This report documents an Independent Review (Red Team) diagnosis of and recommendations for the Sandia National Laboratories (SNL) Human Resources (HR) Program. The review was conducted at the request of the Sandia National Laboratories Human Resources Division Vice President, Charles Emery, and the Human Resources Laboratory Process Reengineering Team Leader, Shirley Wallace. The Red Team review was carried out in August 1994. The work presented represents the consensus analysis and recommendations of eighteen individuals with varied backgrounds, expertise, and experience.

The term "Human Resources" (HR) was used in the Red Team Charter and is used in this report to indicate the organizations, program, and processes used to apply people to the needs of Sandia. People includes both Sandia employees and contractor employees

The diagnosis and recommendations represent an independent and commercial perspective and evaluation of information available at Sandia. Information for the review was drawn from documents provided by the HR Program as well as from presentations, discussions, and interviews in Albuquerque during the week of August 15 to 19. Some of the information is repeated here to support the discussion and is not meant to imply discovery of the information by the review team. However, team members, acting as independent reviewers, may have perceived or evaluated the information from a perspective that differs significantly from that of Sandia HR Program personnel.

The Red Team interviewed several personnel from the Sandia California business unit but did not physically visit that site. The California $\mathrm{HR}$ activity resides within this business unit and is accountable to Corporate HR. The State of California imposes some statutory requirements on the California business unit that do not apply to Sandia New Mexico.

The recommendations address the assets and barriers that, from the ITR team's perspective, provide the highest leverage for movement towards the commercial business standard. As the identified areas are addressed, other second order barriers, not addressed in this report, may require attention to move continuously toward an ever improving commercial standard. 
The report is based on information obtained and conditions observed during the August 1994 review interval. The report does not address changes which have occurred subsequent to the review. 


\section{EXECUTIVE SUMMARY}

\section{Review Synopsis}

The architecture and cost of the Sandia HR Program are fundamentally inconsistent with the commercial business standard. Breakthrough change is required to resolve the architecture and cost issues; minor fixes won't do. Substantial barriers are in the path to this breakthrough change. DOE oversight and requirements do not appear to be driving or limiting HR improvements. Major HR barriers are self imposed.

As a solid foundation for the new architecture, the HR management team needs to begin building a valued-partner customer relationship with the Divisions. To initiate this relationship, solution oriented HR generalists should be placed in the Divisions. The generalists must be backed by a HR Program staff of solution-oriented specialists.

To improve delivery and lower costs, the architecture of the HR Program must be reevaluated and potentially redesigned based on the concept of a business-requirements core set of policies, products, and services. A menu of other optional products and services should be offered to each Division on a cost recovery basis. Cost reduction driven processes and technology must be used to equip and enable the Divisions to flexibly meet their business and people resource needs. The HR Program infrastructure should be consolidated to achieve these purposes.

\section{The Commercial Standard}

In the commercial environment, $\mathrm{HR}$ serves as a strategic partner in a dynamic environment. Its roles and accountabilities are in concert with an established business direction set by the Corporate leadership. It has no agenda of its own. Its focus is enabling the money makers. Operating as a business to business metrics, HR is lean and agile without becoming anorexic.

Hearing and understanding the voice of the business unit customers is the key to a valued HR Program. HR partners with line managers to help them fulfill their people management responsibilities. It seeks solutions within the framework of compliance and competitive advantage. HR establishes customer driven, user friendly processes to efficiently deliver concise, accurate information and to facilitate candid two way communications. HR and line manager individual and shared roles, responsibilities, and accountabilities are clearly understood and implemented in an environment of mutual learning, understanding, trust, and respect. 
$H R$ is a leader in bringing about organizational change. It anticipates environmental and business needs and is a catalyst for needed changes.

\section{Diagnosis}

The Red Team was chartered to provide a commercial business diagnosis of the HR Program as a basis for high leverage recommendations. The Red Team concluded that substantial, interwoven, institutional and program barriers are in the path to commercial-like business practices and that the major program barriers are self imposed.

At the institutional level, there is not an accepted "burning platform" to drive commercial-like business practices. There are multiple views of Sandia's future and the desired work force. In the absence of this burning platform driver, the Sandia Quality Leadership Council (SQLC) and senior management have not provided HR with the unifying leadership, direction, decision making, and sustained commitment required to initiate and support breakthrough change. This may not be surprising since Sandia's culture does not appear to support either team solutions or change.

The HR Program has assets which could serve as a foundation for change. Customers acknowledge that products are being delivered and delivered well in some areas. HR personnel realize that change is required for HR to be a valued contributor to Sandia's future. HR was recently raised in stature to a Division-level activity and the program has ample resources.

The HR Program also has substantial internal barriers to change. The Program is not integrated within itself or with its customer. Line managers' needs and cost are not decision factors in policies, products, and services. There is an internal focus on guarding and administering policies and procedures.

\section{Path Forward Recommendations}

The ITR team recommends that breakthrough to a commerciallike performance standard occur in an integrated, three pronged approach; piecemeal changes will not produce the desired result. HR Management must begin building a valued-partner customer relationship by supporting the Divisions with solution oriented HR generalists; the generalists in turn must be fully supported by a HR Program staff of solution oriented specialists. 
Existing policies, products, and services must be reevaluated based on Sandia's core business requirements. Those policies, products, and services that are determined by SQLC to be essential to Sandia's business strategy become the HR Program core. A menu of additional optional HR products and services should also be approved by SQLC and implementation negotiated with the Divisions on a cost recovery basis.

The policies and core-optional products and services need to be clean-sheet reevaluated and potentially redesigned to equip and enable the Divisions to flexibly meet their business and people resource needs. The products and services must be user friendly, provide concise information, and be cost effective. Technology should be applied when justified by customer driven service improvements or cost reductions. 
THIS PAGE

\section{LEFT BLANK}

\section{INTENTIONALLY}

$$
3-4
$$




\section{RED TEAM PROCESS}

The Red Team used a gap analysis process, as depicted in Figure 4-1, to develop its path forward recommendations. In the gap analysis process, the desired future state is determined, followed by an assessment of the current state. A path forward plan is then developed to close the gap between the two states. Detailed next steps are established to initiate the gap closure effort.

The "Desired State" was defined in the Red Team Charter (See Appendix A) to be commercial best business practice. The Red Team developed a consensus program and work force standard for best commercial practice which is described in Section 5 of this report.

The Red Team developed a snapshot-in-time assessment of the "Current State" of the HR Program by reviewing approximately 4500 pages of documentation, receiving 12 hours of $\mathrm{HR}$ briefings, and conducting 82 individual interviews. The current state assessment includes an evaluation of the environment around the program and a diagnosis of the assets and barriers to change. The general current state assessment is detailed in Section 8 and specific activity diagnosis are in Appendix $C$ of this report.

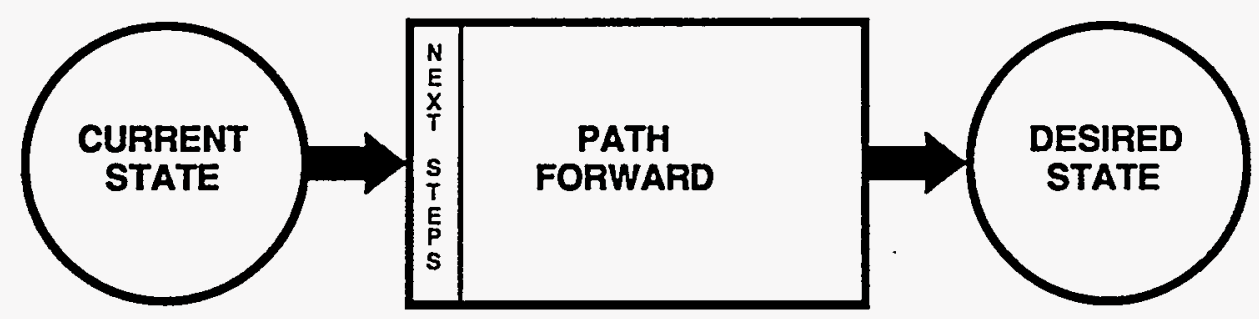
Diagnosis
Recommendations
Best Commercial Practice
Environment
Comparison to Standard
Assets
Assumptions
Path Forward
Specific Recommendations
Red Team Standard
- HR Program
Barriers
- Work Force Attributes

Figure 4-1. The gap analysis process used by the Red Team. 
Using four assumptions about the path forward, the team then developed three overarching gap closure recommendations supported by 17 specific action recommendations. These path forward assumptions and recommendations are described in Section 6 . The Red Team's proposed next steps are listed in Section 7.

The Red Team's path forward recommendations and proposed next steps are presented in this report before the general and detailed current state assessment upon which they were based. The intent is to focus the reader on the gap closure recommendations - the Red Team's value added product. The assessment and diagnosis are merely a means to that value added product. 


\section{Commercial Standard}

\section{$5.1 \quad$ Introduction}

As part of its Charter, the Red Team was asked to describe a "Commercial Standard" against which the Sandia HR Program could be evaluated. Of course, there is no single, identifiable commercial standard in HR. The optimum HR organization is the one that best fits the business and industry in which it operates, and, as with any professional discipline, there is wide variety in the application of advanced HR processes across the broad spectrum of commercial enterprises.

However, there is clear consensus in commercial HR regarding the general characteristics that progressive HR organizations display and general agreement about the changes HR organizations have had to make to help the enterprises they support remain competitive. Similarly, it is possible to articulate the broad attributes that businesses are trying to develop in their work forces in order to capitalize on a key, contemporary source of competitive advantage i.e., the highly skilled, knowledge worker.

This section will describe "A Commercial Standard" for both the $\mathrm{HR}$ organization and the larger work force. It is derived from the collective experience of this particular Red Team, but it clearly reflects common points of agreement that can be found throughout commercial HR organizations.

There are three primary themes that recur in this section, as depicted graphically in Figure 5.1-1.

1. The HR organization must act as a strategic partner with line management and enable the line to respond effectively to a rapidly changing environment.

2. The energy, focus, and human assets of HR must be concentrated on the delivery of consultative, value-enhancing products and services. This will allow for fewer people and less focus on HR's traditional administrative compliance role, although these responsibilities cannot be neglected.

3. The "voice of the customer" must be pervasive in the HR organization and reflected in its offerings and measurement systems. HR must act as a "business" and be accountable for its performance in support of the overall enterprise. 


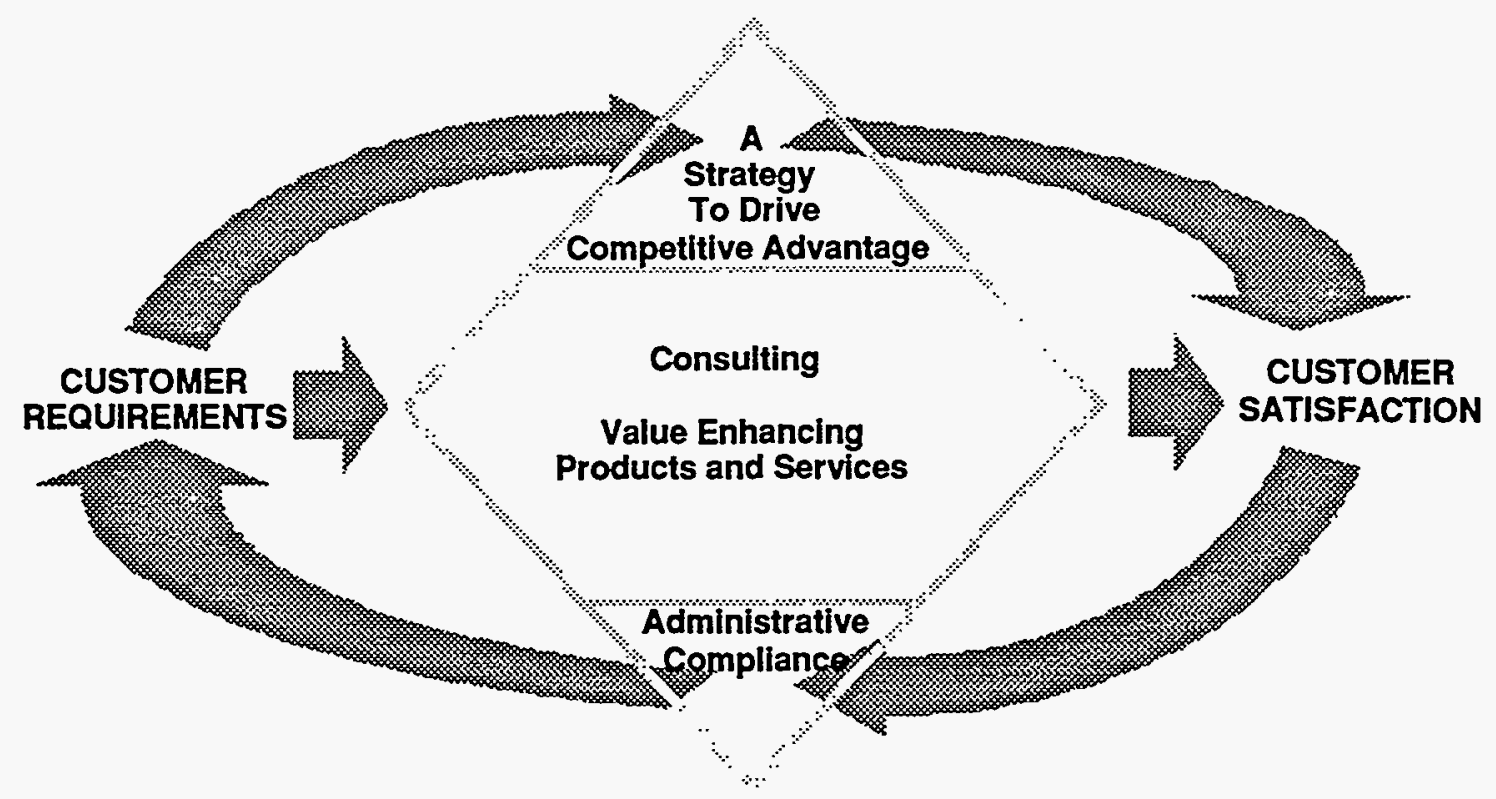

Figure 5.1-1. The Red Team standard for commercial best practice.

In the commercial environment, the primary customers of the HR Program are the line business managers. To aggressively seek out, compete for, and deliver work, line business managers must be assured that their people resource needs will be met. HR's role is to enable the managers by meeting those needs.

At the start of the business activity life cycle, line managers must have the needed people and expertise for the activity just-in-time (JIT). If the people are procured too early, they must be charged to overhead; too late and performance may be in jeopardy. Special skills and training must also be provided JIT to maximize performance and cost efficiency. The corporate business strategy must be designed to provide the quality-of-work-life and total compensation (including benefits) sufficient to attract and keep the desired personnel consistent with business needs. The corporate culture and processes must also support and motivate individual and team productivity and cost efficiency. As major phases of the project are completed, corporate processes must supply JIT personnel redeployment or separation. As is the case with people procurement, early redeployment or separation impacts performance; late redeployment or separation impacts cost efficiency and profit.

The indirect/overhead costs of the HR policies, processes, and services necessary to procure, retain, train, redeploy, and separate people must not be a restricting factor in the line business mangers ability to compete for and win new work. Line managers expect HR to continuously seek 
technology and tools which deliver higher quality products and services at a lower cost.

Successful commercial businesses exploit the opportunities of a ever-changing business environment. Line business managers need HR to provide the tools which leverage and manage change opportunities for competitive advantage. HR is expected to facilitate the dynamic organization designs which will deliver the work in the emerging environment.

\subsection{Enable the Money-Makers}

In recent years, the name of the personnel function has changed to Human Resources. The name change was needed to signify the increasingly responsible and integral organizational role of the function. HR organizations are increasing their influence within their companies by moving beyond the traditional administrative and compliance roles of the personnel function. Today, HR organizations are recognized as having a strategic business partner role in helping their companies achieve their business objectives by using employee's skills and talents to the best advantage.

Never in its history has HR had such an opportunity to affect organizational change. Many of the new problems that management is confronting involve how to effectively downsize, redesign jobs and work flow, increase productivity, improve quality, control benefits, overcome labor shortages and mismatches of skills, involve employees in decision making, and recognize and reward performance. All of these issues impact HR.

The rapidly changing market place requires $H R$ to review its strategies regularly. HR has become a key player in a company's organizational change effort. The core HR processes are not administrative systems; they are the keys to the achievement of strategic business goals. Organizations must have the right skills at the right time and management systems that reward desired results and appropriate behaviors.

Today's HR strategic plans are driven by the organization's overall strategic plan. Effective HR strategic thinking deals not only with the total organization and the environment in which it operates but also with the plans of the major business units. The major HR issues facing organizations today are:

- The changing employment environment (e.g., employability vs. job security).

- Employee performance and productivity (e.g. performance management methods and skills retraining). 
- Compensation and benefits (e.g. health care costs).

- Health and Safety (e.g. OSHA requirements).

There are many other issues facing HR that may be unique to a particular organization. For example, mergers, acquisitions, and entrance into new markets can each impact an organization's HR strategic directive.

The products and services that HR offers today are much more customer driven than those of only a few years ago. In the past, HR had more of a one-size-fits-all approach to delivery of its services. Today, HR's goal is to assure flexibility to respond to the needs of different businesses and different needs within a single business unit.

In developing strategic initiatives, $\mathrm{HR}$ professionals must address the following critical issues in their organization:

- What are the most important organizational issues?

- How many things are likely to be different three to five years from now?

- What types of external and internal changes can we expect in the near future?

- How do we compare to the competition in these critical areas?

- How can we make the best use of technology?

- How can we close the gap between today and where we need to be tomorrow?

Effective HR strategists form partnerships with their customers to set objectives and define priorities. In addition, they approach HR from a systems perspective. They acknowledge the inevitability of change, plan for the future, measure progress, and continuously make improvements to optimize efficiency and effectiveness.

Another major change for $\mathrm{HR}$ is that it is expected to operate as a business. The same bottom line justification that applies to other business units also applies to HR. HR is expected to manage more with less, reduce costs, make the best use of technology, and provide greater strategic value. To achieve this, HR is becoming more consultative rather than administrative, automated rather than manually driven, and lean rather than layered.

Today, HR is expected to show the qualitative and quantitative results of their operations to other managers, where productivity is always the bottom line. Examples are:

- Customer satisfaction

- Cost per hire

- Job-posting response rate 
- Hit ratio

- Job evaluation factor

- Cost to supervise

- Total benefits cost

- Benefit costs per employee

- Orientation cost per employee

- Absenteeism cost

- Cost per trainee

- Employee satisfaction

- Turnover

The HR organization that is internally focused and compliance driven is rapidly disappearing. Today's HR organization must offer solutions within the framework of compliance while also offering the organization a competitive advantage. HR customers expect HR to help employees learn and grow; however, they also expect a return on investment. Today's HR challenges are delivering products and services aligned to the organization's strategic business objectives, assuring flexibility to respond to needs of different business units, applying the best use of technology, reducing the cost of HR services, and continuously improving customer satisfaction.

Role In Organizational Change

HR organizations must transform their primary mission from controlling administrative/personnel management issues to taking a leadership role in bringing about organizational change. There are several kinds of change agent leadership roles that HR professionals can take. They can be a catalyst, process helper, solution facilitator, resource linker, and stabilizer.

Each of these leadership roles will require members of the HR team to form strategic partnerships with line managers and individual contributors so that they are able to anticipate the environmental and business needs which drive change.

\subsection{Partner with Line Managers}

The HR organization has partnered with the line management team to assure its strategies in sourcing, employee development, training, team building, performance management etc. are all directed to achieving the enterprise's strategic objectives.

This interaction by $\mathrm{HR}$ with the line management team is a continuous process of challenging and clarifying the enterprise's direction, so it may respond with the right set of programs, organizational structure, policy 
changes, etc. to enable the enterprise to maintain its competitive advantage. For example, the enterprise's performance management and compensation programs must be in concert with their bottom line objectives.

Additionally, the HR organization works with the line management team in developing programs that enhance the contributions of the enterprise's employees by building the appropriate skills, while also positively influencing the attitudes and culture desired by the enterprise. In essence, HR translates the enterprise's strategy into employee-related objectives.

This is a continuous endeavor to ensure all employee processes are mapped to achieving the enterprise's business objectives while meeting employee expectations. A common theme for most companies today is achievement of customer satisfaction.

An excellent opportunity to quickly develop a partnering relationship with the line management team is offered through implementation of the generalist concept. The generalist, by definition and job design, is the HR partner to the line organization he or she supports. They, in turn, can reinforce the value and contribution of the HR organization by teaming with the line on different projects, bringing to these teams HR specialists to enhance the overall level of contribution. Although the generalist serves as a single point of contact to the organization, recognition by the line of the added dimension and added support provided by the specialists only enhances the overall strength of the partnership.

5.6

Lean and Agile

In the commercial environment, $H R$ has been forced to function more effectively with a much smaller staff while concurrently improving the quality of its products and services. Associated elements of the Red Team's commercial standard are:

- Conduct external benchmarking to ensure competitive advantage and continuously improve products and services.

It is important to 'keep the bar high' so that real, measurable change takes place.

- Operate with minimal structure.

Commercial HR organizations typically are flexible, dynamic, and internally integrated. There is a great deal of interchange between line management and HR generalists. This structure better enables customers to know where to go for HR products and services. 
- Integrate with the business units.

Commercial businesses typically have line HR generalists supported by functional HR experts to ensure exceptional customer service. HR products and services exist solely to fulfill and meet business objectives. HR has no agenda of its own.

- Maintain core competencies - evaluate buying everything else.

As a result of the cost constraints required to remain competitive, most commercial HR organizations staff only to meet the ongoing needs of their businesses. All other products and services are purchased from external sources on an as needed basis.

- Use technology to provide customer solutions at minimum cost.

The effective utilization of technology allows commercial HR teams to leverage their resources, gain economies of scale, and employ people's skills at the highest level. This also helps create the kind of environment where people enjoy coming to work.

- Follow-up, measure, and monitor effectiveness.

Like all members of the business team, commercial HR organizations follow up constantly to make sure products and services meet customer needs. Results are measured using traditional methods as well as those with a process orientation. Other business teams receive periodic reports on progress and effectiveness.

\subsection{Work Force Attributes}

Since the mid 1970s there has been a convergence of political, economic, social and technological forces on the global economy. One of the most fundamental shifts is the relationship of employees, not only to their own work, but also to their fellow workers and the organization.

The changes can be summarized in several ways:

1. Customers are determining organizational strategies and structures. 
Customers are demanding better service and faster response at a lower cost. Organizations that are internally focused and burdened with hierarchy and bureaucracy will be out-performed by organizations that are customer focused, delivering the best solutions in the shortest time. As a result, organizations must develop strategic plans that are customer driven and leadership skills and performance measurement systems that integrate customer satisfaction and financial performance.

\section{Global economies are dramatically impacting labor.}

The cost of labor as a percentage of a product's cost is being reduced. The number of workers needed for a product or service is steadily declining, while the need for employees with multiple skills and competencies is increasing. Organizations are reengineering and restructuring around teams and processes rather than individual jobs.

\section{Values are shifting from job security to employability.}

Employment is no longer viewed as a life-long commitment, but rather as a performance contract that is continually renewed. Employees are being asked to do more with less and share in the organizations risks and rewards. Organizations will need to develop new performance management systems that reflect the changing work force. In addition, new compensation and reward programs must reinforce both individual competencies and performances, as well as those of the team and organization.

\section{Speed and simplicity are becoming the key differentiations for competitive advantage.}

Organizations must find simpler, more user-friendly ways to deliver services and products. Control-oriented, bureaucratic organizations are being replaced by flat lean organizations that encourage decentralized decision making and self managed teams. Work is being redesigned and reengineered to increase flexibility, efficiency, and enable empowered employees.

The work force is changing at revolutionary speed. The twentieth-century industrial organizational model is rapidly becoming obsolete. HR must have a clear understanding of the organization; its vision, mission, values, structures, and culture to facilitate the transition to the flexible, diverse, continually evolving organization of tomorrow. 


\section{RECOMMENDATIONS}

\subsection{Introduction}

The Red Team developed a three point, integrated architecture for a Sandia HR Program with commercial-like performance. The three points are presented in the order of logical implementation: 1) establish a functional day-to-day linkage with the customers, 2) reevaluate and potentially redesign HR policies, products, and services based on Sandia's current and projected business needs, and 3) put the systems and processes in place to enable the Divisions to flexibly meet their business and human resource needs.

The Team also developed specific architectural "beams and girders" recommendations in the context of five functions within which the Red Team saw all Sandia HR activities. These five integrated functions are structured in such a way as to optimize natural synergies of skills, technology, and subject matter, as well as maximize cost effectiveness in applying resources. The functions are:

- Employee and Management Relations

- Resource Management

- Total Compensation

- Organizational and Individual Effectiveness

- Infrastructure

To depict the recommended relationship of the five functions, the Red Team developed the structural model illustrated in Figure 6.1-1. 


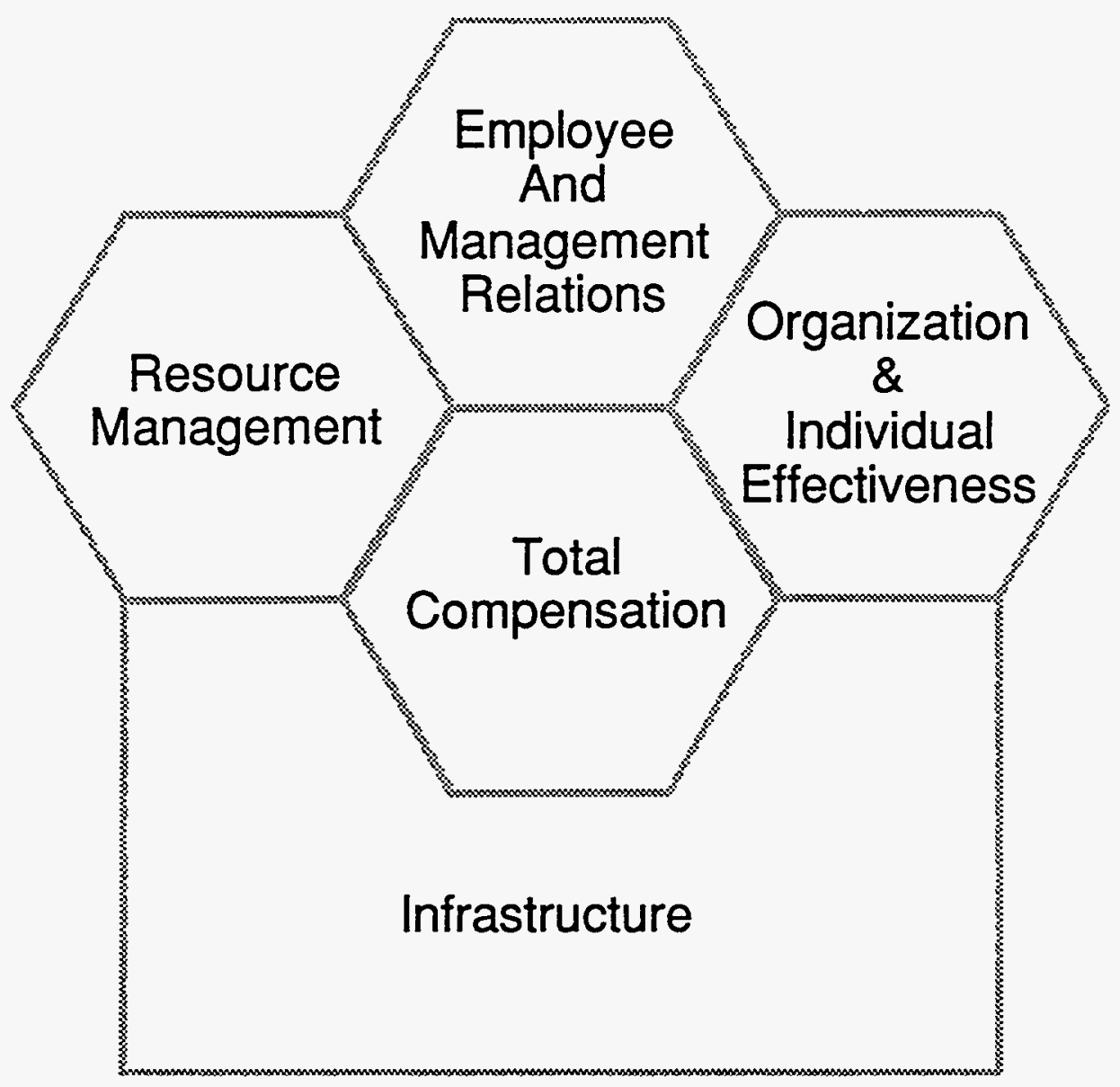

Figure 6.1-1. The recommended HR structural model.

This honeycomb organizational metaphor was chosen because it suggests integration (the antithesis of functional silos), and demonstrates the multiple soft interfaces critical to HR's effectiveness. These interfaces are both internal to HR and to its Sandia management customers. Employee and Management Relations is placed at the top of the honeycomb because of its critical interface role with the Divisions and line management customers. The placement of the infrastructure at the base of the model illustrates the role it plays in support of many of HR's products and services. In many respects it is the platform on which HR processes are based.

The basis for the three point, integrated architecture and the five function "beams and girders" recommendations are developed in this Section. The Red Team did not attempt to develop the remainder of the detailed design solution. This design is best done by the Sandia HR function using its knowledge of Sandia's needs. 
The Red Team based its recommendations on four fundamental assumptions.

1. The HR management team is committed to breakthrough change. The primary evidence for this is the formation of the reengineering team and the charter given to the Red Team.

2. There is a recognition that there are certain institutional barriers to the changes recommended here which will not be easily lowered. These barriers, cited in Section 8.4 of the report, are cultural. Dealing with them per se was not a part of the Red Team charter. The assumption, therefore, is that these barriers may have to be overcome slowly, thus compounding the challenges for HR breakthrough at Sandia.

3. The barriers existing within the HR Program (Section 8.6) can be reduced or removed through effective implementation of these recommendations. In fact, since reduction of these barriers is a prerequisite to breakthrough, this received special focus of the Red Team in the development of its recommendations. The recommendations are intended to address these obstacles as well as the opportunities identified in the diagnosis.

4. By Charter the Red Team was to address the entire HR Organization with the exception of Clinical Medicine. Feedback from customers indicated a high level of satisfaction with the services provided by Medical. It is meeting a number of needs extending beyond Occupational Medicine which appear to be working well for Sandia. It is unclear whether there is a good Medical model for Sandia in the commercial environment. To the degree that it exists as a function, it may or may not belong in HR. The Red Team assumed, therefore, that Medical would be the subject of a separate analysis. Consideration was given to all other HR functions.

The Red Team uses terminology in this section which should be defined. The recommendations differentiate between "core" and "optional" products and services as follows:

- Core - HR policies, products, and services which must be uniform throughout Sandia

- Optional - All other HR activities

\section{3 $\quad$ Redesigned Architecture}

In its diagnosis of Sandia's HR Program, the Red Team concluded that the program was fundamentally inconsistent with commercial standards and not customer friendly. (Details on this diagnosis 
and the commercial standard can be found in Sections 5 and 8.) In this Section, the key elements of a proposed new architecture for the Sandia HR Program are developed. The Red Team recommends that Sandia's new architecture consist of three key elements.

6.3.1

Build a Valued-Partner Customer Relationship by Supporting the Divisions with Solution Oriented HR Generalists; Support the Generalists with a Staff of Specialists

A fundamental change recommended by the Red Team involves the redeployment of the organization's resources, focus and energies away from the enforcement of policy and maintenance of procedures, towards a strategic, consultative role supported by the flexible delivery of value enhancing products and services. To accomplish this, the Sandia HR staff will need a much closer relationship with its primary customer, line management, and a deeper understanding of the business problems faced by customers. Only then can it respond quickly with flexible programs and offerings that enable line management to better accomplish their mission.

The HR generalist is a familiar position on the commercial side of HR. Their specific duties and reporting structure vary by business but their basic role contains common elements. They are highly skilled, experienced HR professionals with multi-functional backgrounds, often including line or HR management experience. They spend most of their time with line management and/or employees, serving as one-stop-shopping contacts to facilitate customer access to HR. They are also the voice of the customer who communicate line management HR requirements to HR management. When programs, products, services or policies are developed in response to these requirements, the generalists often are the primary delivery mechanism to ensure the HR offerings are understood and implemented effectively. In all their efforts they are supported by HR specialists. It is essential that the generalists carry a minimum of transaction based, administrative workload so they can carry out their critical role as the voice of the customer and key $H R$ representative to line management.

The generalist role is further described in Section 6.7.

Conduct a Clean Slate Reevaluation and Potentially a Redesign of the Core HR Policies, Products and Services, Based on Sandia's Business Requirements; Negotiate Optional Products and Services with Each Division

One institutional barrier identified by the Red Team is a preference for a "one size fits all" approach to change. The identification of core but flexible policies and optional products and services is an approach that is now common in industry and well suited to help Sandia move aggressively on a path forward to commercial, competitive practices.

$$
6-4
$$


The concept is quite straight forward. All current HR policies, products, and services are listed and unit costs are developed. Based on commercial experience, this is about a two person-month effort. Several Red Team members supplied detailed background information for this task which is included in Appendix D.

The SQLC, assisted by HR management and the HR LPR team, determines which HR policies, products, and services are mandatory either because they are required by federal, state, or local law, by DOE, by Martin, or by contract. Commercial reengineering efforts have found that this is typically about $30 \%$ of current activities. In addition, and with customer input, the SQLC selects other policies, products, and services as core because: 1) they are key to Sandia's mission or value system and 2) they fit within the high level, commercially-comparable FTE and cost metrics set by SQLC for $\mathrm{HR}$. Some of the remaining HR activities, again at HR management's and the HR LPR team's recommendation, are placed on a menu of optional products and services. They need to be priced and offered to Divisions either individually or in a package of optional services. The line management customers can decline these offerings or purchase similar services from other providers. This approach places HR in a true marketplace. Current HR activities which are neither core or on the optional menu are demobilized.

Commercial experience suggests that marketplace discipline causes HR organizations to better understand their customer's needs, respond faster, with more flexibility, and develop effective mechanisms, like HR generalists and surveys to monitor and ensure customer satisfaction. By definition, many of the services and products selected by the customer are key to their business success since they have chosen to purchase them from limited program/project dollars.

\subsubsection{Enable and Equip the Divisions to Flexibly Meet their Business and People Resource Needs with Cost Reduction Driven Process and Technology}

The focus of first two points is the third point - enabling the Divisions and the line managers to manage their human resources in the most effective and efficient manner possible. By understanding what the customer currently needs and will need and by reducing the policies, products, and services to the core set, HR can focus on customer driven efficient and effective delivery of that core.

The Red Team identified a number of specific "beams and girders" recommendations across the spectrum of HR functions. All of these recommendations deal with important enabling issues, but of critical importance are the two functions - Employee and Management Relations and 6-5 
Infrastructure. First, to create breakthrough change, people management roles, authorities, and accountabilities must be crisply defined by the HR Employee and Management Relations function. Employees, line managers, and HR management and staff must know what is expected of each group to contribute and be successful. Second, to move towards commercial practices, Sandia must review its current infrastructure deployment. Today, this support and Information Systems (IS) resource resides in both a central organization and each HR functional silo, e.g., benefits, medical etc. This infrastructure is critical to enabling and equipping the customers and has common features regardless of the function in which they are currently done. Examples include data entry and retrieval, queries, reports, forms maintenance and processing etc. Deploying these definable, repeatable tasks in silos always results in redundancy and inefficiency. It is clear that Sandia is ineffectively providing information to the customers while using far more people to accomplish the delivery than comparable organizations in the commercial sector.

Sandia should consider consolidating the infrastructure, including IS support, into a single organization that then supports the balance of $\mathrm{HR}$ and the customers. At the same time, by combining this effort with the development of specific HR tools as recommended by the Red Team, Sandia $\mathrm{HR}$ can greatly reduce its labor content and improve the quality of support.

In summary, the Red Team believes that the three points, if undertaken aggressively, can constitute the new architecture that Sandia HR needs to satisfy its customers in a changing business environment.

\subsection{Resource Management}

In viewing the set of sub-processes which comprise what the Red Team saw as Resource Management, a number of recommendations are being put forward which may be taken as a set or, in some cases, may be taken as individual and separate recommendations. To achieve optimum benefit, these suggestions should be viewed as a whole.

\subsection{1}

\section{$\underline{\text { Resource Plan }}$}

In line with the HR teams' plan to develop a skills data base for Sandia, using Resumix, the Red Team suggests that endeavors continue and be expanded to include skills of those in the contractor base. As some Divisions may be diverted from quick turnaround in providing this data, $H R$ may wish to set an achievable target of $70 \%$ to $80 \%$ for development of the initial data base. In parallel with this activity, the HR team, working with line management and Sandia's strategic plan, should develop an outlook of skills needed by the Divisions. At completion of these two activities, a gap analysis should be conducted to identify the skills deficit and skills surplus. This analysis will serve as a basis to evaluate the extent to which anticipated 
requirements can be addressed by redeployment and retraining. This will enable an analysis to determine whether hiring, outplacement or a layoff must be considered to meet Sandia's strategic objectives.

\section{- Outplacement}

The Red Team recommends that Sandia consider adding a formal outplacement capability (outsourced) to its HR repertoire to assist those employees who are no longer a match for the skill needs of Sandia. Such an approach fits well with the employability concept, providing a more positive way of assisting employees to make the transition from Sandia to other work.

\section{- Layoffs}

Although a very painful process for both employees affected and those that remain, the Red Team recommends that HR develop an "on-theshelf" layoff plan for the following reasons:

First, in a non-pressure environment, a number of alternatives for reducing resources can be studied to determine potential yields and cost to Sandia. Some examples are early retirement programs, reduced work weeks (only if a short term bubble situation), job sharing, bridge-leaves, leaves of absence, etc. If work fall-off is detected early, there may also be new business solutions that may be sought to cover the anticipated work reduction.

Secondly, the contract or buffer workload and contractor staff can be studied to determine if this is truly a buffer. It would appear, however, that a large percentage of the current contractor staff skills are clearly needed as they are doing different work from that of the regular staff. Also, it is only with some business forecasting that a realistic assessment of the redeployment and retraining yields can be appropriately assessed.

The Red Team also recommends that a formal assessment and business justification be developed that supports the current continued employment or employment for life philosophy. Traditionally, growth, skills, retention, flexibility, cost effectiveness, reduced career anxiety and commitment to the entity have justified such an approach. Once the business justification is completed, it would provide a vehicle to enable periodic testing of the approach, as the business dynamics of Sandia change.

\subsection{2 $\quad$ Resource Direction}

Because of the continued global business pressures and the changes in the U.S. defense needs, resulting from the end of the cold war, the Red Team recommends Sandia embark on a resource strategy of employability vs. employment for life. Or said in another way, "equipped to 
stay, prepared to go." This approach is common and growing in the commercial world. It shifts career responsibility to the individual and retention responsibility to the employer. The employer provides a work environment that utilizes the individual's skills while providing the opportunity for the employee to enhance his or her skills for career growth and flexibility. As this will require a different focus by the management team, Sandia should consider introducing the concept of a dual managementtechnical ladder structure for the organization. This concept would give added flexibility and enable the movement in and out of management of those employees best matched for the changing demands of management in a dynamic organization.

To enhance and broaden the employees' perspective of the commercial environment, Sandia may wish to implement a commercial sabbatical program. Considering both the diversity and unique skills available, Sandia has a lot to offer industry. A first step could be assignments with Martin. The Red Team also recommends expanding work force flexibility options in the areas of flex schedules, part-time work options for regular employees, longer leave of absence options, and work-at-home (telecommuting).

\subsection{3 $\quad$ Resource Model}

The Red Team suggests HR couple with Sandia's business strategy to develop a three-year plan for sourcing and staffing the requirements of the laboratory. In line with an employability focus, HR may wish to create job position templates that carefully match specific scope of work to skills required. A job position template is a general skills need statement that is much more dynamic than a typical job description. The template could be supported by one or more job descriptions or, in fact, lead to the creation of a new description(s) if a job theme emerged. The job templates are dynamic in that some areas of skill/job need will be changing quickly, as new and changing missions are brought into the different Divisions and an accurate description is needed for both redeployment and hiring. A number of experienced professional hires may be needed and on short notice; templates would facilitate this hiring. Templates also support with the broad banding recommendation described in Section 6.5.1.

Anticipating significant and possible rapid changes in business demands, HR may wish to have the plan constructed on a year-by-year basis. This would also facilitate tuning of the regular and contractor base. Again, from an employability perspective, such a plan would enable an internal scan to identify both areas that will experience change and employees who will become available, who would be candidates for retraining and redeployment. Also, HR may need to adjust from a predominantly campus based recruiting program to a mix that includes more experienced professionals. 


\section{- One Focal Point for all Hires / Placements}

The Red Team strongly recommends that both Sandia and contract recruitment and selection be conducted by the HR employment functions. The criteria for hiring a contractor should be the same as for a regular hire, and the process should be the same.

One resource pool using Resumix should be used for all hires. Once the hiring decision is made, a contract should be prepared and released by the purchasing organization. Such an approach would assure the hiring of top candidates, better meet compliance requirements, and facilitate diversity objectives.

\section{- Leadership Development Program}

As an adjunct to the transition to an employability approach, the Red Team recommends several programs to identify key management and technical leadership talent. An early assessment program should be conducted after the first year of employment to assess the hiring decision and determine if an employee should be retained or released. The decision to release could be eased by the use of a formal outplacement program, as previously mentioned. As part of the first year assessment, a futures potential could also be gauged to identify someone who, on a very preliminary basis, has demonstrated such outstanding potential that they should continue to be evaluated as potential candidates for leadership positions.

To assure a pool of highly qualified candidates to fill key management and technical positions, the Red Team recommends the development of a formal succession planning program to attract and develop a small number of employees considered to have excellent leadership skills. The program must be dynamic and structured to be quite flexible to the changing leadership needs. As the business changes, the requirements and demands will also change.

The program cannot be static, it must accommodate changes by being fluid, allowing the inclusion and exclusion of candidates. As the business changes, it should be expected that employees will come on and off the list, based on the dynamics of business need and performance. This program would also provide assistance in achieving Sandia's affirmative action objectives and diversity goals.

\section{- Employee Information}

The Red Team recommends that Sandia's new employee orientation program be expanded to include a general overview of Sandia-its history, organization structure, mission, strategic objectives and culture. 
It is also suggested that HR conduct a formal exit interview process to gain an employee's perspective of their job and of Sandia as they leave the laboratory. Such a program may serve as an early identification of problem areas or highlight possible trends that may be emerging.

\section{- Equal Opportunity / Affirmative Action}

Affirmative Action (AA) objectives have to be incorporated in all aspects of the previously mentioned programs. Each program suggested offers the additional opportunity to address and assess needs and achievement of AA goals and objectives. As mentioned elsewhere in this report, the Red Team supports the separation of diversity from EEO/AA. It is also suggested that the compliance aspects of EEO be clearly defined and be a separate function within the EEO/AA organization.

\section{5}

\section{Total Compensation}

Total Compensation as viewed by the Red Team includes all elements of compensation, rewards, and benefits distributed to employees. While a number of potential recommendations were considered, the Red Team decided to focus on four specific areas which it believed had the greatest potential payback for Sandia and HR with regard to customer satisfaction, quality, and cost effectiveness.

\subsubsection{Broad Banding/Job Classification vs. Job Evaluation}

The Red Team was concerned that a project was apparently being undertaken to expand the job evaluation process to the technical jobs to replace the current reliance on maturity curves. While continued use of maturity curves may not be the solution for Sandia, there are other methods, more in line with commercial practices which would address Sandia's needs without adding unnecessary and costly bureaucracy to the process.

Currently up to nine individuals are involved in job evaluation, the process requires anywhere from one to as many as six weeks (elapsed time) per job, and approximately $120-150$ jobs are evaluated per year. This is compounded by frequent appeal of evaluations which require many hours of management and HR time, often resulting in exceptions which compromise the integrity of the evaluation process for everyone. The Red Team believes that rather than move toward individual job evaluation for the technical jobs, adoption of a broad banding approach to slotting jobs should be applied to both technical and non-technical jobs.

Job evaluation systems such as the Hay System were developed and became popular during the $60^{\prime} s$ and $70^{\prime} s$ when there was greater focus on structure and stratification. Such systems enabled assigning a point value to 
jobs which implied a precise distinction between jobs so that they could be viewed in a hierarchy. It fit the business environment of the day where American producers competed only with each other, controlled the market, and didn't have to worry so much about speed and agility.

Today that same level of precision is no longer valued, takes too much time and energy, and prevents management from being as agile as it must be to compete in a global environment. Sandia is also now competing for a shrinking marketplace, and must be able to adjust more quickly if it is to compete effectively with other labs. Going to a broad-banding system not only enables quicker assignment of jobs within the structure, thus allowing Sandia to maneuver more deftly when trying to lure potential outside candidates, it also facilitates internal movement of people because it enables movement with reduced focus on job level.

\subsubsection{Support to Performance Management Process Implementation}

The Performance Management Process (PMP) currently being implemented at Sandia is consistent in design with commercial practice. While it was reported that there was low acceptance by line management, the Red Team believes that the problems are not with the design, but rather with the implementation and communication. The Red Team urges continuation of the launch, but with consideration of a number of supporting actions which should help neutralize some of the cultural resistance.

A strong reaction to implementation of the program resulted from the roll-out of PMP without a specific tie to base and non-base pay. There was also indication of some resistance by management, particularly technical management, of having to deal with constructive criticism when giving one-on-one feedback.

As a means of giving greater focus to the value of effective $H R$, the Red Team suggests establishing an HR Award to be given to the a) most effective manager, or b) most effective Division VP for Human Resource Management during the year. This award could be presented at the annual Employee Awards Night, by the CEO or COO, and carry with it the same level of prestige as the most prestigious awards represented for technical achievement. This would be one way for top management to demonstrate to the rest of the organization the importance they place on effective management of the lab's most important competitive advantage.

Another way to focus attention on the importance of people management is to designate a prescribed percentage of each manager's PMP weighting for HRM. The suggested approach would be for increasing the weighting for each management level e.g., 15\% for Department Managers, 
$20 \%$ for Center Managers, 25\% for Division VPs and above. This would have the effect of focusing attention on the importance of people management, and would, in time, become another Sandia tradition.

\subsection{3}

\section{Linkage of Non-base Pay to Achievement of Enterprise Direction}

Feedback from managers and employees reflected dissatisfaction with the current system of delivering both base and non-base compensation. They cited inconsistency of application as well as a view that the non-base was a take-away (consistent with the entitlement thought process) as reasons for their dissatisfaction.

Delivery of non-base pay is common in the commercial sector and in this regard Sandia has taken a significant step forward. Best practice in the commercial environment provides for the delivery of non-base pay in three ways, 1) reward for short term individual achievement, and 2) reward for delivery of critical enterprise or 3) a mix of the two. Sandia appears to have implemented the first of these with some level of effectiveness.

Managers and employees interviewed did not show dissatisfaction with the short term individual recognition delivered. There is a major opportunity for Sandia to get a greater return on its investment of the remainder of its non-base compensation budget. Delivery of these funds should be tied to clearly understood and effectively communicated objectives at two levels: the Sandia level, and the Division level.

One way to achieve greater focus on enterprise direction is to broadly publicize Sandia corporate annual objectives. Bring special focus to two or three of these by tying achievement (and over-achievement, if that is appropriate), to delivery of non-base pay. Do the same thing for each Division so that each employee's opportunity to earn non-base pay is based on achievement of five or six common objectives (two or three at the Sandia level and two or three at the Division level).

This means that all employees in any Division would earn (or not earn) their non-base opportunity based on a combination of Sandia and Division level performance. It also means that employees in different Divisions may have different non-base earnings levels if their Divisions deliver different levels of performance. Finally, it means that if Sandia and/or the Division does not deliver its annual objectives the full level of non-base pay will not be paid out.

The effect of this change will be the following:

- Greater focus on common business objectives 
- Peer pressure supports management efforts with below average performers

- Reduced view of non-base pay as an entitlement

Sandia has already overcome what is the greatest obstacle most commercial entities have faced in implementing this type of program - that is budgeting for it. Sandia management has already had the foresight to establish this budget. The remaining task is to tie delivery to accepted business objectives.

\subsubsection{Benefits Design}

The quality of the benefits offered to Sandia employees compare very favorably with those offered in the commercial world. The recommendation in this area relates to optimizing employee satisfaction with benefits through effective communications. While viewed positively by employees, it appeared that no one actually knew what the benefits were really costing Sandia, and whether Sandia was optimizing its investments in terms of a employee satisfaction vs. cost comparison.

There is also little understanding of which benefits are most important to employees. Senior HR management should assess which benefits will be core (universal) and which will be optional. This can be accomplished through frequency of use studies and through meeting with employee focus groups. Once cost and employee information is know, enlightened decisions can be made as to which benefits to maintain, which to make, which to buy, which to make core, and which to make optional.

It appears that employees may not know the value of their benefits. One of the reasons employers offer benefits programs is to promote employee retention. Sandia employees have no frame of reference for comparing what they have to anything else. In fact, employees knowledge of their benefits is typically restricted to those they have used.

To address this, the Red Team recommends development and implementation of a benefits education (communication) campaign. This should include use of multi-media, e.g., print, video, and audio, all timed in such a way that employees are frequently reminded that they have excellent benefits, how they may be used, and how they compare to relevant outside organizations. In this way Sandia can be more assured that it is getting its money's worth for its substantial investment in employee benefits.

\section{6 \\ Organizational and Individual Effectiveness (O\&IE)}

The Red Team recognized a connection among several existing HR functions. These functions are all involved with individual and organization development or educational outreach. On the basis of document 
reviews, briefings, and interviews, the Red Team, recommends that HR establish an Organizational \& Individual Effectiveness (O\&IE) component. The Red Team provided the following additional recommendations concerning the current HR division and the proposed O\&IE organizational unit within $\mathrm{HR}$.

- Decouple Diversity, EEO/AA and Education Outreach Processes

- Combine Community Outreach and Education Outreach

- Focus Individual and Career Development Programs on Core Competencies

- Expand the charter of the Management \& Leadership Development Function

Each of these recommendations was framed against commercial best practices. The Red Team also developed an action plan, and considered barriers to success, benefits to be achieved, and potential liabilities. Placing these functions in a single organization would potentially prove economical and provide a more consistent set of tools and services.

Customers served by O\&IE are line managers and individual contributors, educational institutions, community outreach groups, and educational outreach groups. O\&IE becomes accountable to its customers for specific responsibilities including consultation, needs assessment, and training to line management, recommending vendors and evaluation of vendor products, (conducts evaluation levels 1 through 4), and leads workshops. Process consultation, issue identification and resolutions, curriculum design and coordination, and both program and course development logic are also services offered by O\&IE. The Red Team proposes an alignment of existing responsibilities as illustrated in Figure 6.6-1.

An O\&IE component would provide the necessary alignment of products and services with customer needs as they create desire for risktaking, innovation, and cost consciousness; be catalysts in forging partnerships with outreach groups and with in-house customers; be major proponents and practitioners of total quality leadership; and champion individual differences. 


\begin{tabular}{|c|c|c|c|}
\hline $\begin{array}{l}\text { Community \& } \\
\text { Educational } \\
\text { Outreach } \\
\end{array}$ & $\begin{array}{l}\text { Individual \& Career } \\
\text { Development \& } \\
\text { Education }\end{array}$ & Diversity & $\begin{array}{l}\text { Org. Effectiveness \& } \\
\text { Mgmt. Development }\end{array}$ \\
\hline $\begin{array}{l}\text { Community } \\
\text { Development }\end{array}$ & Career Planning & Change Strategy & Org. Design \\
\hline $\begin{array}{l}\text { Outreach to Under- } \\
\text { represented Groups, } \\
\text { such as: } \\
\text {-Summer Employ- } \\
\text { ment for Native } \\
\text { Americans } \\
\text {-Summer } \\
\text { Employment for } \\
\text { Minority Youth } \\
\text {-One-Year-On- } \\
\text { Campus } \\
\text {-Graduate Degrees } \\
\text { for Minorities in } \\
\text { Engineering }\end{array}$ & $\begin{array}{l}\text { Managing } \\
\text { Professional Growth }\end{array}$ & $\begin{array}{l}\text { Leadership } \\
\text { Involvement \& } \\
\text { Commitment }\end{array}$ & $\begin{array}{l}\text { Intervention Planning } \\
\text { \& Implementation }\end{array}$ \\
\hline $\begin{array}{l}\text { K-12 Science } \\
\text { Education Programs }\end{array}$ & $\begin{array}{l}\text { Individual } \\
\text { Effectiveness }\end{array}$ & $\begin{array}{l}\text { Employee } \\
\text { Participation }\end{array}$ & Change Management \\
\hline $\begin{array}{l}\text { Science Advisors } \\
\text { (SCIAD) Resource } \\
\text { Center }\end{array}$ & $\begin{array}{l}\text { Employee } \\
\text { Redevelopment } \\
\text { Center }\end{array}$ & $\begin{array}{l}\text { Awareness and Skill } \\
\text { Building }\end{array}$ & Supervisory Skills \\
\hline $\begin{array}{l}\text { Post Secondary Progs. } \\
\text {-College \& Univ. }\end{array}$ & $\begin{array}{l}\text { Train-the-Trainer } \\
\text { Activities }\end{array}$ & $\begin{array}{l}\text { Issue Identification, } \\
\text { Resolution, \& } \\
\text { Feedback }\end{array}$ & Project Management \\
\hline University Faculty & $\begin{array}{l}\text { Coaching for Career } \\
\text { Development }\end{array}$ & Communications & Financial Mgmt. \\
\hline $\begin{array}{l}\text { Electronic } \\
\text { Networking Liaison } \\
\text { with central function }\end{array}$ & & $\begin{array}{l}\text { Integration with HR } \\
\text { Functions in Support } \\
\text { of Diversity }\end{array}$ & $\begin{array}{l}\text { Employee Surveys } \\
\text { Leadership \& Mgmt. } \\
\text { Development }\end{array}$ \\
\hline Doctoral Study Prog. & & Reward \& Recogn. & $\begin{array}{l}\text { Corporate Education } \\
\text { \& Training (MMC) }\end{array}$ \\
\hline In-house Dissertation & & $\begin{array}{l}\text { Empowerment \& } \\
\text { Teaming }\end{array}$ & $\begin{array}{l}\text { Train-the-Trainers } \\
\text { (both line \& HR) }\end{array}$ \\
\hline
\end{tabular}

Figure 6.6-1. O\&IE Products and Services Alignment.

As part of the proposed reconfiguration, some products and services can be considered for assignment to other organizations for delivery to customers or eliminated. For example, approval for educational assistance and the Fast Start program can be moved to line managers and secretarial training can be moved to local trade schools. Corporate development programs and corporate training and development activities can be eliminated. Orientation for new staff can be transferred to Staffing and to the appropriate line managers. ES\&H Training should be moved into the ES\&H organization. Office automation training can become a responsibility of the

$$
6-15
$$


CIO Organization. Continuing Technical Education and Compliance activities can be moved into local colleges, to the line managers and ethics. O\&IE would offer professional products and services including:

- Pre-College Support Programs

- K-12 Teacher Training Programs

- University \& Graduate Programs

- SCIAD Resource Center

- HBCU/MEI Programs

- Graduate Programs

- University Faculty Programs

- Interactive Computer Based Training

- Consulting

- Employee Opinion Surveys

- Technical Training Programs \& Courses

- Train-the-Trainer Programs
- Self Study Learning

- Recommend Vendors \& Evaluate Products

- Career Planning and Coaching

- Organization Design

- Strategic Planning Facilitation

- Intervention Planning \& Implementation

- Change Management

- Diversity Reward \& Recognition Programs

- Diversity Awareness \& Skill Building Programs

- Diversity Exec. Council \& Employee Team Facilitation

- Diversity Strategy

The Red Team examined the question of skills mix for the O\&IE staff. BA/BS, MA/MS degrees in business, the social sciences and/or human resources with a minimum of five years experience in one of the appropriate HR functional areas are desired. Other skills should include conflict management, ability to interface with employees at all levels in the organization up through the President, program management, design and development, and process consultation. O\&IE staff must be willing to take risks, lead courageously, and demonstrate tenacity.

It will be important for O\&IE to interface with many groups and foster strong alliances and constituencies. This will require initiative and leadership. O\&IE must be responsive to and consider the needs of all HR process owners, line managers, employees, outside agencies and organizations, subcontractors, vendors, and consultants.

Performance metrics must be established within O\&IE. These metrics should be periodically monitored and carefully evaluated. They could include, as examples: comparison against strategic and action plans; customer satisfaction surveys; interviews with generalists and line managers in individual Divisions; use of SCIAD educational kits; groups serviced by community and educational outreach program; and feedback from subcontractors, vendors, and consultants.

The Red Team suggests that the O\&IE budget request be tied to their annual strategic and action plans. O\&IE could reduce its current total

$$
6-16
$$


headcount by $50 \%$, exclusive of Educational Outreach. This reduction would need to be carefully planned, phased, and linked to program transfers, functional elimination and O\&IE's strategic and action plans.

\subsection{Employee and Management Relations}

The Red Team viewed Employee and Management Relations as three functions: Employee Relations, Labor Relations, and Management Relations. To enhance the quality of performance in these three functions the Red Team has three recommendations:

- Develop clearly defined roles, HR responsibilities, and HR accountabilities for line managers.

- Create a consulting organization (HR Operations) which integrates HR generalists into the line organizations.

- Acquire additional strategic direction from senior management to enhance the effectiveness of Labor Relations.

The first enables management to clearly identify what is needed for managers to successfully manage their HR needs in the same manner that they manage the other business requirements of their departments, while forming a powerful partnership with HR. The second creates a dynamic organization which allows HR generalists to reside in the line organizations while acting as a delivery arm for $H R$ processes, a receiver of line requirements for $\mathrm{HR}$, and a catalyst for process improvement. The third allows for Labor Relations to be part of the overall strategic process which will produce a greater proactive capability in the Labor Relations organization.

\subsubsection{Develop Clearly Defined Roles, HR Responsibilities, and HR Accountabilities For Line Managers}

Commercial practice demonstrates that managers have the same accountability for managing the HR aspect of their business as they do for any other business requirement. The roles and responsibilities associated with this accountability must be clearly defined and explained to the organization. The VP of HR must assume a leadership role in this endeavor, and must define the concept to the other members of the SQLC and solicit their support.

The VP of HR will need to meet with line management to define individual Division requirements. While there will be a set of core requirements common to all Divisions, there will exist the need to address some individual requirements in each Division. A charter will then need to be jointly agreed upon which will define these requirements, and responsibilities for delivering them. 
A new position description for managers should be developed. This new description will clearly describe the new responsibilities incumbent on all managers relative to the HR management requirements of their positions.

\subsubsection{Create a Consulting Organization (HR Operations)}

Commercial practices suggests that Employee Relations be redefined as Human Resources Operations and staffed with a group of highly skilled professional HR generalists. These generalists will have a very broad and detailed understanding of human resources which has been obtained over many years of practicing in the HR discipline. While these individuals will reside in the line organization, they will report to the HR Division. These positions will have accountability to both $\mathrm{HR}$ and the line organizations, and the line will have significant input to performance assessment. Once these positions are established, Sandia may make a future decision to have these positions report to the line organizations.

To approach best practices standards, Sandia will first need to define the organizational structure and design appropriate job descriptions. It is recommended that the organization be led by a Director level position and further consist of eight (8) senior level generalists (HR Managers) supported by ten (10) junior level generalists. A potential deployment of the above staff would be:

\begin{tabular}{ll} 
Division & Staff \\
\hline 1000 & 1 HR Mgr \& 1 Support \\
2000 & 1 HR Mgr \& 2 Support \\
$4000 \& 5000$ & 1 HR Mgr \& 1 Support \\
6000 & 1 HR Mgr \& 1 Support \\
7000 & 1 HR Mgr \& 2 Support \\
8000 & 1 HR Mgr \& 1 Support \\
9000 & 1 HR Mgr \& 1 Support \\
$3000,10000,11000,12100,13100$ & 1 HR Mgr \& 1 Support
\end{tabular}

It is estimated that six to twelve months will be needed to fully implement this new organization. The implementation schedule is dependent on individuals with the requisite skills and experience being available.

\subsubsection{Acquire Additional Strategic Direction From Senior Management To Enhance The Effectiveness Of Labor Relations}

Current commercial practice suggests that Labor Relations be more closely aligned with the overall strategic direction of the enterprise. It could function more proactively if it were viewed more strategically by senior 
management. Senior management should involve Labor Relations in the strategic planning process and develop a partnership approach in how its Labor Relations' activities are conducted.

\section{$6.8 \quad$ Infrastructure}

\subsubsection{Introduction}

The Infrastructure function should constitute an underlying base or foundation for supplying basic facilities, equipment, processes and other support needed for the functioning of a system or organization.

The shape of an infrastructure can range from a dispersed set of recognized responsibilities spread over functional units, to an arrangement of dedicated units with different reporting lines, to the ultimate concentration and focus of infrastructural responsibilities in a single component.

HR does have in place a sizable capability (approximately 17 FTEs) in the HR Information Systems (HRIS) organization. Furthermore, there are additional, substantially similar resources, at least equal in number, "owned" by other HR components. HRIS promulgates and maintains "The Human Resource Information Systems Plan." Despite the existence of these resources, the Red Team observed that within the Sandia HR Organization, the recognition for the need of an integrated approach to infrastructure appears to be lacking.

\subsubsection{Infrastructure Recommendations}

The path forward envisions a clean-slate reevaluation and potential redesign that would culminate in a cooperatively developed and corporately approved "directory" of core and optional Sandia HR policies, products, and services. Concurrently it is imperative that Infrastructure must be recognized, defined, established, and energized to design and implement processes, tools, and systems that deliver the products and services.

The Red Team recommends that Sandia provide a seamless, cost-effective technology HR Infrastructure linking line managers, employees, HR professionals, and external contracts with the following actions: 1) consolidate MIS and other appropriate resources in a single unit, 2) develop specific deliverables with aggressive schedules based on line's prioritized business requirements, 3 ) immediately use existing systems to provide enhanced functionality, and 4) establish automated self-service for people transactions.

The Red Team further recommends that the Infrastructure organization provide strategic planning and continuous improvement for HR services or products, including the following: 
1) implement a quality process improvement team,2) prioritize or close all HR initiatives based on the HR Strategic \& Business Plans, 3) with senior management input, define HR core competencies and implementation skills, and 4) develop meaningful metrics and milestones with customers.

\subsection{3 $\quad \underline{\text { Benefits }}$}

The most significant benefit would be through the combination of baselining and achieving a mutual understanding of the required and optional policies, products, and services while concurrently establishing the capability of delivery at a level close to commercial standards and in a costeffective manner. Other benefits include:

- HR administrative work minimized; facilitates role of value-added consultants.

- High cost/benefit payback

- Projected savings $\sim 35 \%$, >\$4M over 2 years.

- Immediate service; great increase in customer satisfaction.

- Important measures of quality of products and services to customers.

- Process and results can be designed against competitive industries.

- Results can be managed.

- HR priorities and action plan understood, communicated, and implemented.

- Resources balanced to HR priorities.

- HR has unit responsible for planning with administrative and line unit peers. 


\section{NEXT STEPS}

The Red Team has developed a series of recommendations related to resource management, total compensation, organizational and individual effectiveness, employee and management relations, and infrastructure which collectively comprise an integrated path forward to an HR breakthrough. The recommendations that are described in the preceding sections of this report also reflect the "next steps" necessary for implementation of the recommendations. However, there are several overarching near-term actions that predicate successful achievement of a breakthrough to commercial best business practices in the Sandia HR processes.

\subsection{Define and Adopt the Path Forward}

The HR Laboratory Process Reengineering Team and the HR Management Team should jointly and mutually assess, evaluate, accept, and adopt the agreed upon path forward.

\subsection{Recommended Path Forward to the Reengineering Steering Committee}

The HR Laboratory Process Reengineering Team should carefully review the institutional barriers that have been identified, as well as others that may exist, and develop a strategy for mitigation. The path forward should be presented and recommended to the steering committee by the LPR Team. Particular attention should be drawn to the evaluation and redesign of the core HR policies, products, and services because it is integral to the path forward and will require subsequent SQLC involvement in deliberating and endorsing the corporate core requirements.

\subsection{Add Additional Expertise to the HR LPR Team}

The magnitude, complexity, and duration of the reengineering process are such that the LPR Team should consider inclusion of additional key HR managers to broaden the base of expertise, and to provide for coverage in important, sensitive areas such as Labor-Management relations. Furthermore, the LPR Team may wish to acquire the services of external HR experts to assist in the evaluation and redesign.

\subsection{Develop an Internal Communications Plan}

HR should inform and advise its managers and employees "up front" and on a continuing basis of the fundamentals of the path-forward journey and the concomitant impact; seek understanding, acceptance, and 
participation; and report progress in accordance with a communications plan. Such a plan should be developed in conjunction with the LPR Team. The LPR Team also has important communications responsibilities involving Sandia Corporate Management, HR customers, labor-management organizations, and possibly external bodies. The LPR Team should consider engaging a communications expert to assist in developing and executing its approach to communications.

7.5

\section{Adding a "Breakthrough" Manager}

The HR LPR initiative is expected to be intensive, dynamic, and of extended duration. Continuing to provide ongoing services and support to its customers while undergoing change and transformation will place significant stress and burden on HR management and employees. Communications, coordination, and integration of activities will likely produce complexities and difficulties which the HR Vice President may find impossible to oversee and concurrently fulfill his role as a Sandia corporate official. A "Breakthrough Manager" could relieve the HR VP of the necessary and important day-to-day responsibilities of managing the provision of service and implementation of change. 


\section{GENERAL DIAGNOSIS}

In response to the Independent Review of the Sandia HR Program charter as detailed in Appendix A, a week of HR Program presentations, review of the documents listed in Appendix B.1, and interviews and meetings listed in Appendix B.2, the Red Team has the following diagnostic assessment of the Sandia HR Program. In this assessment, the Red Team will provide an introduction to the diagnosis, an overview of the current Sandia environment, a comparison of the Sandia HR Program to the Red Team Standard, and a summary of HR Program assets as well as institutional and HR Program barriers.

\subsection{Introduction}

An Independent Review of the Sandia HR Program was conducted by a diverse team of highly-skilled, professionals from commercial, governmental and independent businesses. The Team's research included a comprehensive review of documents (the Sandia Strategic Plan, the HR Strategic Plan, and 4500 pages of HR Program documentation) as well as meetings and interviews (12 hours of HR Program briefings, 82 interviews with HR personnel and customers). Based on this information, the Red Team formulated the following high-level program diagnosis.

The architecture and cost of the Sandia HR Program are fundamentally inconsistent with commercial business practices. Minor fixes won't do.

The Red Team observed the approach of the Sandia HR Program to time allocation, resource allocation, and line management customer interface with HR organization and found it to be very different than that which is found in the commercial market place. Sandia's HR Program is structurally removed from the customer and is three times more expensive than the commercial standard for similar size companies.

Substantial, interwoven institutional and program barriers are in the path to a HR breakthrough.

The goal is a breakthrough change for Sandia HR. The Red Team found that there are significant barriers to be minimized or eliminated if any change is expected. These barriers are institutional, barriers which cut across all of Sandia, as well as contained within the HR Program. The Red Team believed the HR Program barriers could be eliminated but believes that the institutional barriers may have to be overcome slowly. 
DOE oversight and requirements do not appear to be driving or limiting HR improvements. Major HR barriers are self imposed.

The Red Team reviewed the Appendix A of the Sandia contract with the DOE, interviewed key DOE field officials, and reviewed the current funding level for the HR Program within Sandia. Based on this review, the team concluded that DOE is neither a driver or an impediment to HR Program improvements. The DOE customer was in fact receptive to and looking for new ideas and opportunities. The major barriers to the HR Program improvements appear to be self-imposed.

An elaboration of this high-level diagnosis and the supporting case and rationale for these statements will be provided in the sections that follow. But first, it is important to understand the view of the current Sandia environment that was presented to the Red Team.

\section{$8.2 \quad$ Current State}

In order to begin a diagnosis of any part of an organization, the environment in which the company as a whole operates must be examined. In the past five years, Sandia National Laboratories' operating environment has changed considerably. Environmental awareness, restoration, and waste management, the collapse of the Soviet Union, the end of the cold war, and increased concerns regarding the erosion of the nation's high-technology industrial base present new challenges and opportunities for Sandia.

Sandia's traditional nuclear weapons $R \& D$ role for Defense Programs is rapidly declining as reflected in the Figure 8.2-1 from the Sandia 1994 Strategic Plan draft. 


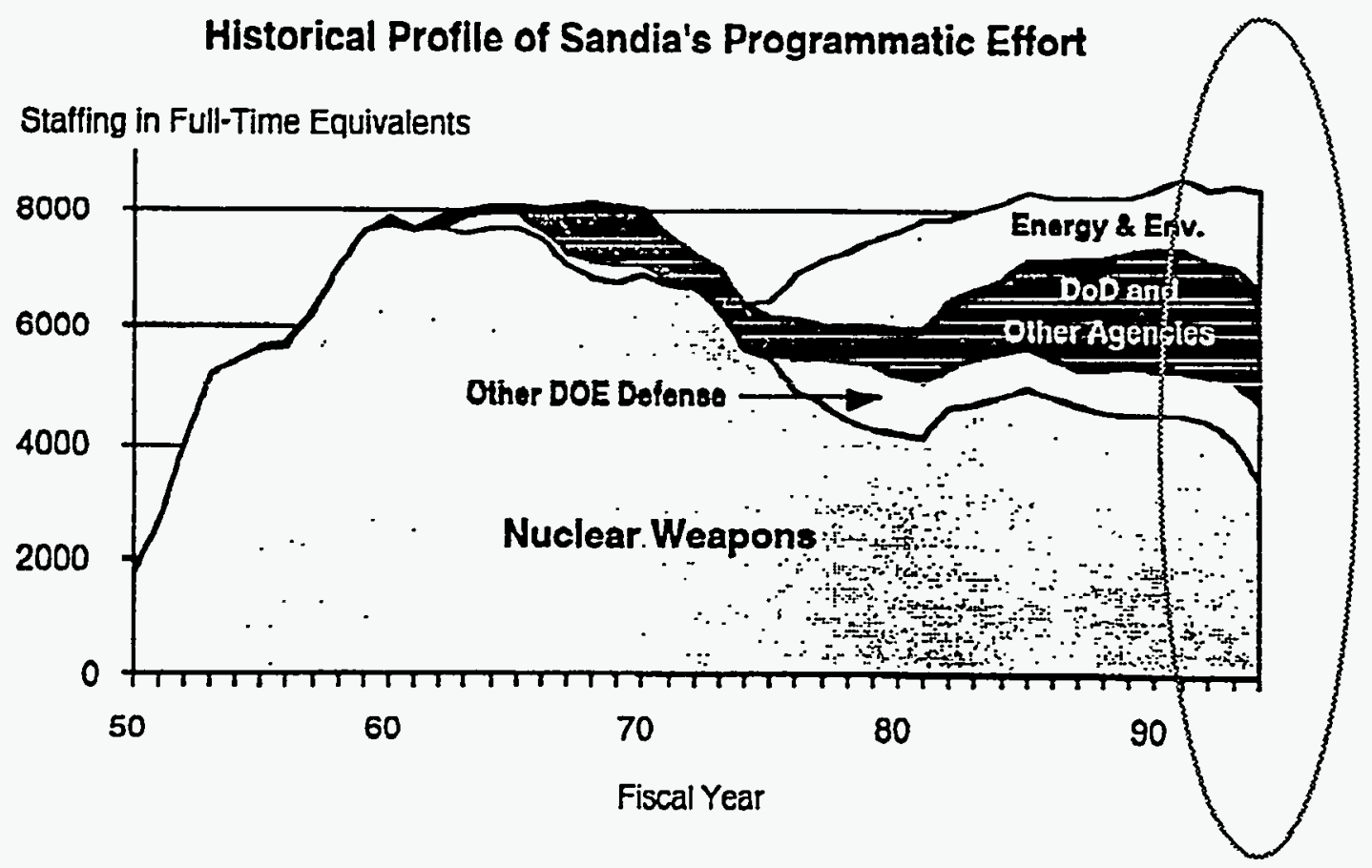

Figure 8.2-1. Changing Sandia operating environment as a result of declining Defense Programs work.

The Sandia 1994 Strategic Plan draft also recognizes that the role of the national laboratories is being debated and that changes need to be made. "Clearly, we will be expected to manage and operate the Laboratories more cost effectively than ever before. Modern business methods, agility and flexibility, and reengineered work processes will be required to meet this challenge. But even with these changes, we will continue to feel the constraints of declining program resources."

With the major source of Sandia's funding declining, new and different customers need to be identified. The Energy and Environment (EE) sector is seen as an area where Sandia can provide solutions to energy and environmental needs. The Work for Others (WFO) sector also has areas of growth. New initiatives in the Industrial Competitiveness sector are being sought. In addition, Sandia has assumed production responsibilities, as requested by DOE, for certain non-nuclear components, and by Energy and Environment for production of molybdenum- 99 for medical applications.

With changes in the customer mix, a new HR approach is needed, both in terms of skills mix and cost effectiveness. Both EE and WFO representatives stated that a different skills mix is required to meet their customers' requirements and it is needed now. EE, WFO and the DOE are 
concerned that the cost of highly skilled and paid, retrained nuclear weapons staff would not be acceptable to their customers. The staff needed for production assignments also require different skills. In addition, redeployed staff, may not be satisfied with the type of work required in these new areas.

For a company with a successful history and an employment tradition of job security, the current environment presents quite a dilemma and a strong case for change.

\subsection{Change is Needed}

Sandia is transforming itself from a government weapons laboratory into a multi-dimensional laboratory that will provide services for defense and civilian agencies and commercial customers. As noted in Sandia's 1994 Strategic Plan draft, "Sandia faces a serious institutional challenge...in real terms, budgeted weapons R\&D funding for 1995 will be lower than at any time since 1952... and has declined by $15 \%$ in each of the last two fiscal years." These trends coupled with increased competition in the EE sector could result in funding declines of unprecedented magnitude. Sandia will require drastic cost reductions in general and administrative organizations to survive and be competitive.

Other external changes in the R\&D world are also effecting Sandia. According to a recent article "Industrial R\&D: The New Priorities" in the September 1994 IEEE Spectrum, "lean times have come to research and development...the number of scientists and engineers is not going up companies are relying more on alliances, technological partnerships and the licensing of technology." For example, IBM's Research Division decreased employment by $19 \%$ from 1992 to 1993 . R\&D contract work is requiring labs to spend "20-30\% of time occupied with bringing in business" according to James Carnes, CEO of the David Sarnoff Research Center in Princeton, NJ, General Electric's spin-off for-profit research laboratory.

The changing business dynamics present a compelling case that change is needed. In addition, a shared belief for major change was expressed during the interviews with the HR Program personnel and their customers. As is evidenced in Table 8.3-1, the Red Team Standard was used as a basis to reflect the opportunities for improvements recognized by the HR organization, their customer base, and the Red Team itself. 
- HR's roles and sccountabilities are in

\section{HR CUSTOMERS RT} concert with an established business direction

- Enable the money makers

- Products and services support achievement of business goals

- Solutions within the framework of compliance and competitive advantage

- Operale as a business; measure against business metrics

- No agenda of is own

- Clearly delined roles, responsibilities, and accountabilities

- Mutual leaming, understanding, Inust, and respect

- Become lean and agile without being anorexic

- Products, services, and costs continuously benchmarked and improved

- Minimal structure

- Tolal integration with the business units

- Maintain core competencies - ovaluate buying everything eise

- Use technology to provide customer service at minimum cost

- Follow up, measure, and monitor effectiveness $x$

$\mathbf{X}$

$\begin{array}{lll} & \mathbf{X} & \mathbf{X} \\ & \mathbf{X} & \begin{array}{l}\mathbf{X} \\ \mathbf{X}\end{array} \\ \mathbf{X} & & \mathbf{X} \\ \mathbf{X} & \times & \mathbf{X}\end{array}$

$x$

$\begin{array}{ll}\mathbf{X} & \mathbf{X} \\ \mathbf{X} & \mathbf{X} \\ \mathbf{X} & \mathbf{X} \\ \mathbf{x} & \mathbf{X}\end{array}$

$x \quad x$

$\mathbf{x} \quad \mathbf{x}$

$\begin{array}{ll}\mathbf{x} & \mathbf{x} \\ \mathbf{x} & \mathbf{x} \\ \mathbf{x} & \mathbf{x} \\ \mathbf{x} & \mathbf{x} \\ \mathbf{x} & \mathbf{x}\end{array}$

$x$ ise:tifted ijy sonis

$X$ Consistently identified

Table 8.3-1. Shared belief that major change is needed in the Sandia HR Program.

The HR personnel interviewed identified several areas which needed to be improved within the Sandia HR Program. The areas identified by the " $X$ " were consistent themes throughout the interview process. The areas identified by the " $x$ " were areas identified by some of the personnel.

In summary, the HR organization saw the major opportunities for improvement coming from alignment of program offerings with the business needs, competitive structure and costs, a definition of roles and responsibilities and mutual trust and respect. The customers interviewed identified a greater number of areas requiring improvement within the Sandia HR Program. The emphasis focused on enabling the money makers, partnering with the line managers, and driving agility and flexibility without going below a critical mass.

The Red Team identified these areas for improvement, but in addition, identified the need to align HR's role and accountabilities with the established business direction and to take on a leadership role to bring about organization change. These areas were not identified by the HR Program personnel or customers, however, the Red Team saw this as a commercial practice that was needed by Sandia. 
The dynamic business environment at Sandia, the national refocusing of $R \& D$ laboratories, and the internal recognition of the need for change begin to support the first premise of the diagnosis which is the HR Program architecture and cost are inconsistent with commercial practices and the needs of the Sandia today and in the future. The diagrams in Figure 8.3-2 demonstrate the fundamental inconsistencies between commercial practice and Sandia's HR Program. This diagram compares the HR model created by the Red Team against Sandia's HR impact model. Although the comprehensive explanation of the Red Team model is covered in Section 4 of this report, it is important to point out the contrast between these two models.

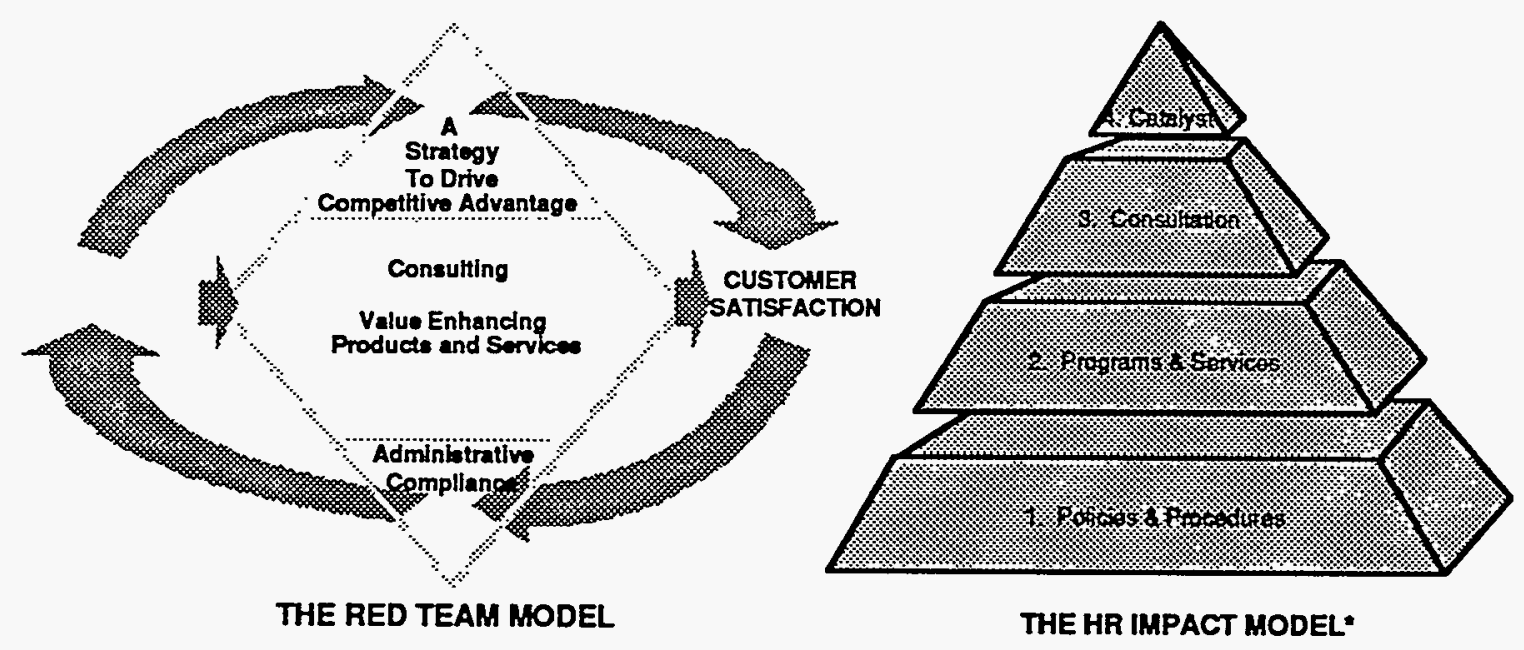

Figure 8.3-2. The HR program architecture is inconsistent with commercial practice.

The Red Team model presents an HR organization which has as its main driver the voice and needs of the customer. There is a small, focused effort providing the necessary administrative services to Sandians, but most of the effort is shifted to providing strategic and value-enhancing products and services. In this environment, $\mathrm{HR}$ would act in a consultative role to the business.

The HR impact model, Sandia's model of its future HR organization, depicts a fundamentally different approach. To begin with, the base of the triangle indicates most effort (resources, people) are devoted to the administration of policies and procedures, designing and delivering of products and services, with a smaller emphasis on consultation and being a catalyst for change. In this model, the customer is not shown.

The fundamental inconsistencies between the Red Team model and Sandia's HR model are demonstrated in the deployment of resources, 
allocation of cost, the focus on the customer and the role of the HR function in the business.

Many companies represented by the Red Team, as well as competitors and collaborators of Sandia, have already made significant progress in reengineering Human Resources to be a more streamlined, customer-focused organization. Table 8.3-3 compares Sandia's HR Program headcount and investment with that of commercial businesses participating in a 1993 Saratoga Institute Study. There are more than 1200 companies of the size of Sandia which participated in the Saratoga Institute Study. This benchmark by no means is the best-in-class or commercial best practice but it does represent an industry standard.

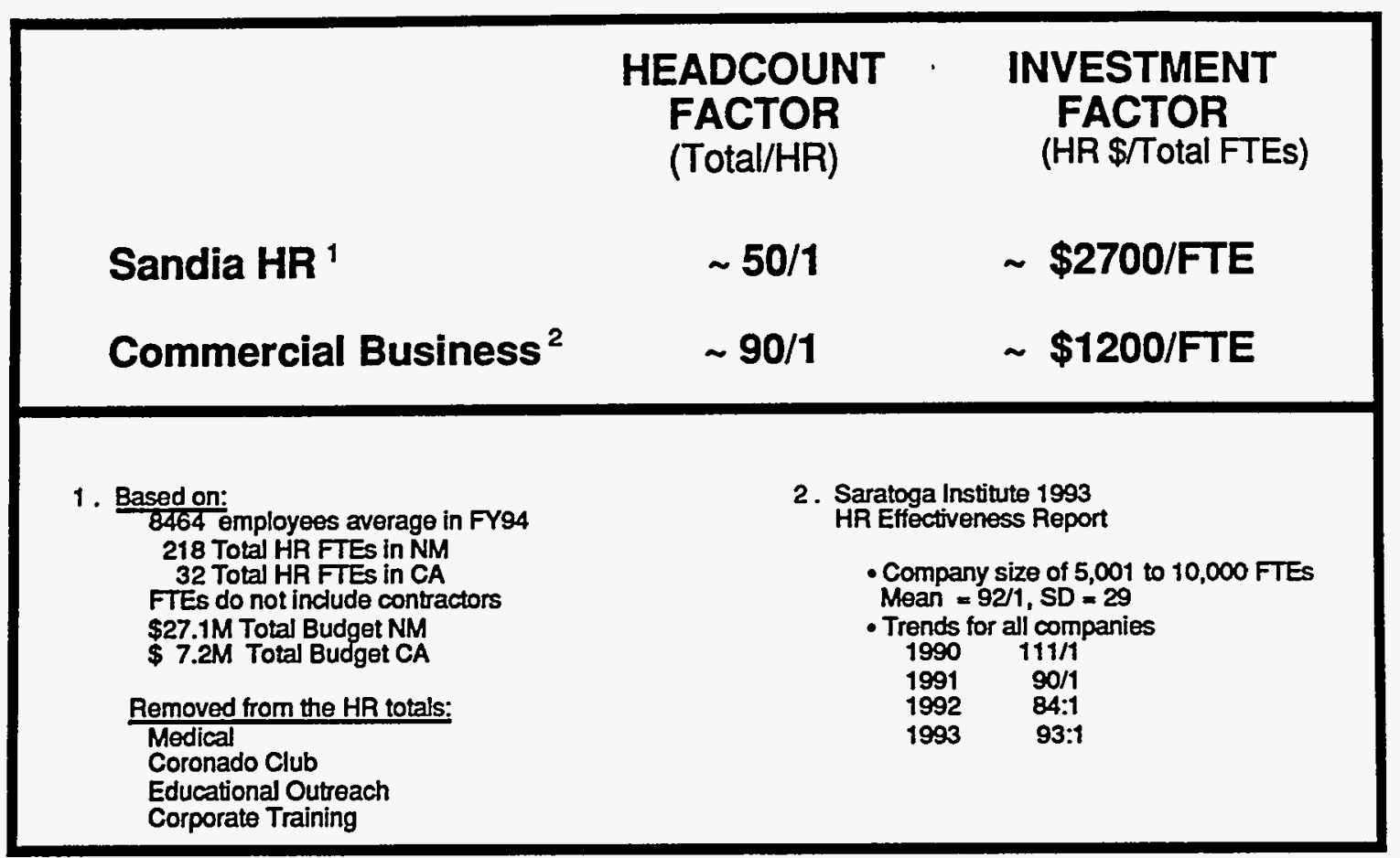

Table 8.3-3. Comparison of commercial HR performance metrics to data on the Sandia HR program.

The headcount factor metric shows that Sandia's HR Program serves $50 \%$ less people than those companies represented in the Saratoga Institute Study. Commercial businesses serve approximately 90 employees for each HR professional on staff. Currently Sandia HR services 50 employees for each HR professional on staff. This ratio for Sandia HR is conservative since it removes from the HR headcount and cost base the Medical, Coronado Club, Education Outreach, Corporate Training and contract personnel and costs who are within the HR Program Budget. 
The Investment factor metric shows that Sandia's HR Program is also approximately twice as expensive as commercial companies of similar size. Sandia's HR Program costs are approximately $\$ 2700$ per Sandian as compared to the commercial benchmark of $\$ 1200$ per employee.

The Red Team has demonstrated how the Sandia HR Program cost is inconsistent with the commercial model. The program architecture is also inconsistent with the objective. The commercial model depicted the driver as the voice and needs of the customer. The Red Team's perspective of the current Sandia HR Program architecture is that it is customer friendly, as depicted in the illustration Figure 8.3-4.
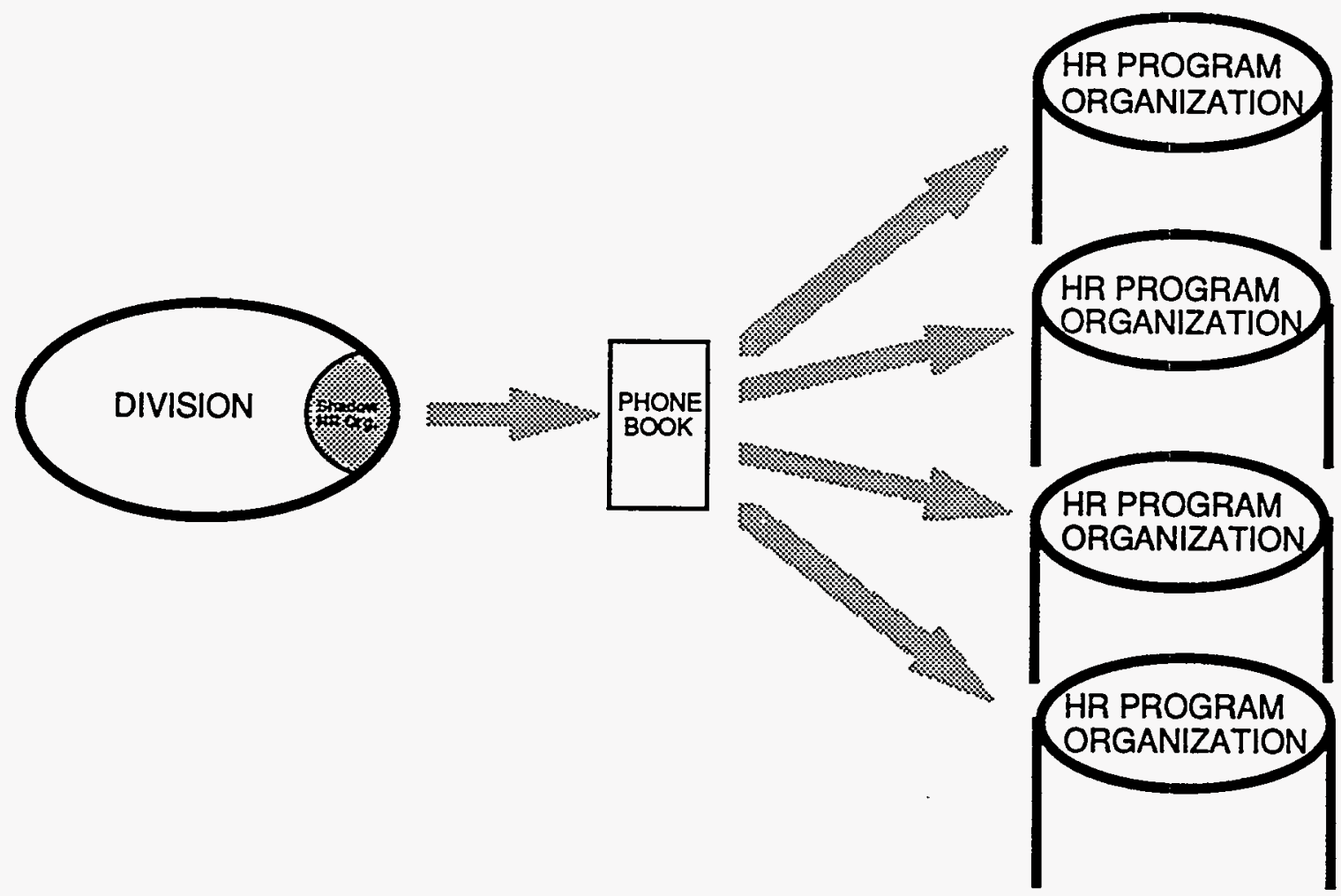

Figure 8.3-4. The current HR Program architecture is not customer friendly.

The current Sandia HR Program is structured into independent functional silos. There is very little evidence of interaction between the HR functions and knowledge of the organization's overall goals, objectives, issues or needs. The HR Program is removed from the customer and driven largely by the individual program managers' perceptions of what needs to be accomplished rather than as a strategic response to a business need.

Line management uses the Sandia phone book as the predominant method to access the HR organization's products and services. 
The customer often makes multiple attempts to get the product or service they need. The HR Program is not integrated or "seamless" to the customer. Consequently, the Divisions have created "quasi" or shadow HR organizations which may support some strategic needs of the business but generally serve as administrative support. These shadow organizations are made up of people such as the personnel representatives, administrators or even the Ombudsman, but none are trained HR professionals.

This HR Program architecture has led to customer dissatisfaction and excessive cycle time and cost.

\subsection{Institutional Barriers}

The Red Team identified four institutional barriers which inhibit change in the HR Program; perception of a need for change, unifying direction from senior management, Sandia's culture, and the characteristics of the desired work force.

There is not an accepted "Burning Platform" to drive change.

The success and reputation of Sandia was achieved in a noncompetitive environment. While senior management is currently considering reengineering, the overall lab funding has remained relatively steady through FY-1994. There is, therefore, no "burning platform" to drive the organizational changes to become cost conscious and business competitive. Staff, however, are concerned about the lab's future and offered many examples for improvement in efficiency and cost savings. Mixed within their concern are the strong desires to preserve the Sandia culture as existed under the AT\&T contract.

\section{Senior Management have not provided HR with unifying} leadership, direction, decision making, and sustained commitment.

Lack of unifying senior management leadership was evident in the absence of accountability for the success of implementation of initiatives. Sandians interviewed were not able to articulate the success or failure of current or past initiatives because measurable outcomes were seldom defined other than numbers of staff attending training or meetings. A common response was that many previous initiatives just went away. Sandia has, or formerly had, initiatives in empowerment, restructuring, change management, quality, senior management focus retreats, diversity, champion teams, labor management councils, ombuds and reengineering. Some were dropped because of the perceived implementation risk and others because they were no longer being supported. The Sandians interviewed who were champions of current initiatives, were excited and hopeful, but were realistically aware that their projects could be a fad with a short life. 
Sandia has many diverse and internal conflicting perspectives on the future staffing and the desired skills of current employees. Senior management has not created an HR strategy which refleccts the changing dynamics of the lab's work load.

Throughout Sandia examples were identified where departments, by necessity, had contract workers providing essential project support while simultaneously having Sandians who were underutilized. The allocation of FTEs to Divisions remains a critical, but generally not understood, process. Few Sandians interviewed felt the allocations were based on the current and future work load. The Finance Department manages the FTE allocation and HR is not significantly involved. Divisions and Departments stated that they cannot realistically plan for the future without agreed upon work load and HR strategy.

The culture does not support team solutions and change.

The technical line managers appropriately possess the power within Sandia. The commonly accepted culture is that unless all the line vice presidents are supportive of an initiative initially and remain so throughout, laboratory change does not happen. The interviewees from the line, HR staff, and other administrative units spoke of the difficulty and lack of trust for problem solving through collaborative efforts. Technical organizations, without concern for costs, create duplicate support functions when they do not perceive they are receiving required services. The staff in service Divisions did not seem to perceive that more importance should be given to service delivery to the "money making" Divisions.

\section{Sandians hold many views of the desired work force.}

Sandians feel deeply that a layoff of unneeded or underutilized staff should be avoided at nearly all costs. Many of the interviewees spoke of individuals in their work unit who had no productive work. They also acknowledged that they were hiring workers on contract to provide essential new skills. However, many spoke with a reverent pride of Sandia's ability to avoid a layoff.

The range of perspectives heard from Sandia staff illustrate the lack of consensus on the desired skills for the future work force:

- Maintain the credentials standard set by the nuclear weapons complex and AT\&T Bell Labs.

- Attract and retain the best weapons research and design personnel. 
- Minimize the risk of involuntary separations through maintaining a ceiling on Sandia employees.

- Do not employ additional staff for transitory new initiatives.

- Use only Sandians for important work, hire contractors for the rest.

- Minimize the costs of administrative personnel.

- Employ the best possible university technical graduates through the use of pay and benefits and once employed find them a position.

- Build and maintain a diverse work force with attention to skills, perspectives, culture and age.

- Attract and retain the right personnel skill mix to accomplish all work in a cost effective manner.

These divergent views of the desired Sandia work force can be mutually exclusive.

Comparing the Sandia work force with the commercial model, Table 8.4-1, this divergence is further reenforced.

\section{SANDIA}

HIERARCHY \& BUREAUCRACY
ENTITLEMENT
INWARD FOCUS
INDIVIDUAL CONTRIBUTORS

JOB SECURITY

SILO FOCUS

UNIFORMITY

RISK AVERSE

CONTROLLING

CREDENTIALED

DIRECTIVE MANAGEMENT

INFLEXIBLE

\section{STANDARD}

FLAT LEAN ORGANIZATIONS

EMPOWERMENT

EXTERNAL FOCUS

INDIVIDUAL CONTRIBUTORS AND

CROSS-FUNCTIONAL TEAMS

EMPLOYABILITY

TEAMING

DIVERSITY

PRUDENT RISK TAKING

EMPOWERED

SKILLED

SELF-MANAGED

AGILE

Figure 8.4-1. Sandia work force attributes compared to the commercial model. 
The Red Team recognizes that this comparison is based on a very small sample, however, these attributes were evidenced in the HR work force and the Sandia work force overall. Implementing the Sandia Strategic Plan need to incorporate "modern business practices" within Sandia will clearly be a significant challenge.

The Red Team recognized that these are significant barriers which may be lowered slowly. The recommendations provided in Section 6 recognized this issue and are structured to accomplish change in this environment. There are other barriers which must be removed as the implementation plan is being formulated and those are found within the HR Program itself.

\subsection{Assets Foundation for Change}

There are a number of current assets that can be used and leveraged to support the needed changes within Sandia. The appointment of a Vice-President of HR was a positive action. It is an acknowledgment of the true importance of the human resources management task ahead for Sandia.

Currently, some HR products and services are being adequately supplied. The HR organization had several areas that were acknowledged by the customers as good efforts, such as Occupational Medicine, Benefits, Educational Outreach, TLC and Diversity. This recognition generally came where the product focus and knowledge provided the autonomy and control of $\mathrm{HR}$ and where line management did not have the expertise to question or recommend alternative approaches.

Sandia has a history of high-achievement and sustained performance. This is a legacy that can be built upon and extended. All the members of the HR organization that the Red Team interacted with were motivated to perform to high standards. There was an authentic desire to "make a difference" for the work force of the laboratory. The commitment to making the organization a viable partner in a successful business was obvious. In addition, there was a strong internal recognition by the HR organization that change is required. What is needed at this point is a new direction and connectivity with the line management customer.

The Red Team believes that today there are ample HR Program resources. Current resource levels are substantially over what commercial organizations have learned to adapt to. 
Unlike the institutional barriers, the program barriers are within the HR organization's control, and therefore, easier to change. The Red Team has identified three barriers:

needs.

Products and services are not aligned with line management

Business requirements and line management inputs are not the basis for selection of HR products and services. The HR staff provides a number of products and services without first determining their value to the business. The cost of products and services are not calculated and not factored into the selection of products and services.

A pattern of exception requests do not initiate an assessment of the current policy or practice. Therefore, the policy does not change and the exceptions become an institutionalized practice. Line management's perception is that HR staff first considers "why not" rather than focusing on "how to help."

customers.

HR is not functionally integrated within itself or with its

There has been no concerted effort to define the line management role relative to HR processes. There is an assumption by line management that the HR organization is entirely accountable for all HR decisions. However, it is unclear as to which HR silo is responsible for what decisions. This is exacerbated by a lack of clearly defined roles and accountabilities within the HR organization.

Appropriate contacts for line management within $H R$ are unclear. Additionally, the different $H R$ organizations function as individual "silos" and are not united in a common direction that supports line management. Therefore, the processes aren't optimized, consume resources, and keep everyone very busy.

\section{There is an internal focus on guarding and administering policies and procedures.}

HR determines the products and services to be provided to line management. There is an HR assumption that line management is neither capable nor willing to be accountable for its HR actions and that the HR Organization knows what's best. HR builds processes from a control perspective with checks and approvals to insure line management does "the right thing." HR has become the guardian to insure no wrong doing. 
The problem is compounded by confusion about the intent and ownership of the current policies. This results in inconsistent application of those policies. The perception of line management is that the situation and the requester drive interpretation rather than fundamental policy. 


\author{
APPENDIX A \\ CHARTER AND REVIEW PLAN \\ FOR AN \\ INDEPENDENT REVIEW \\ OF THE \\ SANDIA HUMAN RESOURCES PROGRAM
}

\author{
CHARTER
}

\title{
A.1.1 Mission
}

The Independent Review Team (Red Team) is to assess the Human Resources (HR) Program based on commercial best business practices and is to recommend a path forward to cost effective, quality, customer oriented improvements.

\section{A.1.2 Objectives}

\section{A.1.2.1 Program Diagnosis}

Identify internal and external program opportunities, barriers, strengths, and weakness with respect to commercial practice.

Team 1 Focus Areas:

- Planning, Basis, and Work Logic

- External and Internal Customer Requirements Identification

- Orders and Standards

- Resource Requirements

- Systems and Processes Development and Implementation

- Policy Development and Implementation

- Processes, Practices, and Metrics for:

- Benefits

- Diversity

- Educational Outreach

- Employee Assistance

- Health Promotion

- Job Evaluation and Compensation

- Labor Relations
- Organizational Development/Effectiveness

- Performance Appraisal and Management

- Performance Based Training

- Personnel Development

- Sickness Absence Program

- Staffing (internal and external)

- Workers Compensation

- Infrastructure/Enabling Activities 
Team 2 Focus Areas:

- Clinical Medicine Processes, practices, and metrics

Diagnosis Exclusions:

- Individual Compensation Information

- Salary Survey Information

\section{A.1.2.2 $\quad \underline{\text { Path Forward }}$}

Recommend an integrated path forward that could be followed to enhance or maintain human resource utilization while improving the HR Program cost effectiveness, quality, and customer orientation. Provide potential next steps to implementation of this path forward.

\section{A.1.3 Interfaces}

The Red Team will perform its activities under the oversight of a HR Laboratory Process Re-engineering (LPR) Team designated Director.

\section{A.1.4 Access To Sandia UCAI Information}

Access to some Sandia Human Resources Unclassified Controlled Access Information (UCAI) may be required to complete the diagnosis objective. The need to access this information will be determined by the Red Team Leader and approved by the HR LPR Team designated Director. A controlled copy will be made available for review but will not be reproduced in any form, including the formal presentations and reports. Non-disclosure statements will be obtained from team members prior to access to UCAI information.

\section{A.1.5 Organization}

The Independent Review Team will be led by Douglas Weaver; Manager of the Capability Assessment Program Office 6604.

Red Team 1 will be staffed by 10 to 12 individuals who are independent of the Sandia Human Resources Program and who have commercial, DOD, and DOE M\&O experience and expertise in one or more of the following areas:

- Benefits

- Diversity

- Educational Outreach

- Employment Law

- Employee/Labor Relations

- HR Systems and Processes
- Personnel Development and Training

- Performance Management

- Policy Development

- Productivity Improvement and HR Cost Management 
- Human Resources Strategy Development

- Job Evaluation and Compensation Systems

- Leadership and Management Development; Organizational Development
- Re-engineering

- Sandia Programs and Projects

- Staffing and Recruitment

- Total Quality Management

Red Team 2 will be staffed by 3 to 4 individuals who are independent of the Sandia Human Resources Program and who have commercial, DOD, and DOE M\&O experience and expertise in clinical medicine.

The teams may elect to call upon additional expert consultants for supporting information or analysis.

\section{A.1.6 Schedule}

Charter Approval

\section{Team 1}

Staff Team; Collect Program Documents

Review Plan Development; Document Review

Diagnostic Review @ Sandia

- Program Presentations

- Interviews

- Tours

Reading/Discussions/Benchmarking

Recommendations Workshop @ Sandia

Presentation to the HR LPR Team

Draft Report to HR LPR Team
July 20

July 25 to 29

August 1 to 12

August 15 to 19

August 22 to 26

Aug. 29 to Sept. 2

Sept. 9

Sept. 30

\section{Team 2}

The schedule for Red Team 2 will be set at a later date and added to the Charter.

Additional time may be taken upon recommendation of the Red Team leader and upon approval of the HR LPR Team designated Director.

\section{A.1.7 Deliverable}

The Red Team will summarize its diagnosis and recommendations in a formal presentation. A written report will be prepared and delivered to the HR LPR Team which will document in detail the diagnosis and recommendations for each objective element. 


\section{SANDIA HR PROGRAM}

\section{INDEPENDENT TECHNICAL REVIEW PLAN}

\section{A.2.1 $\quad$ Review Work Logic}

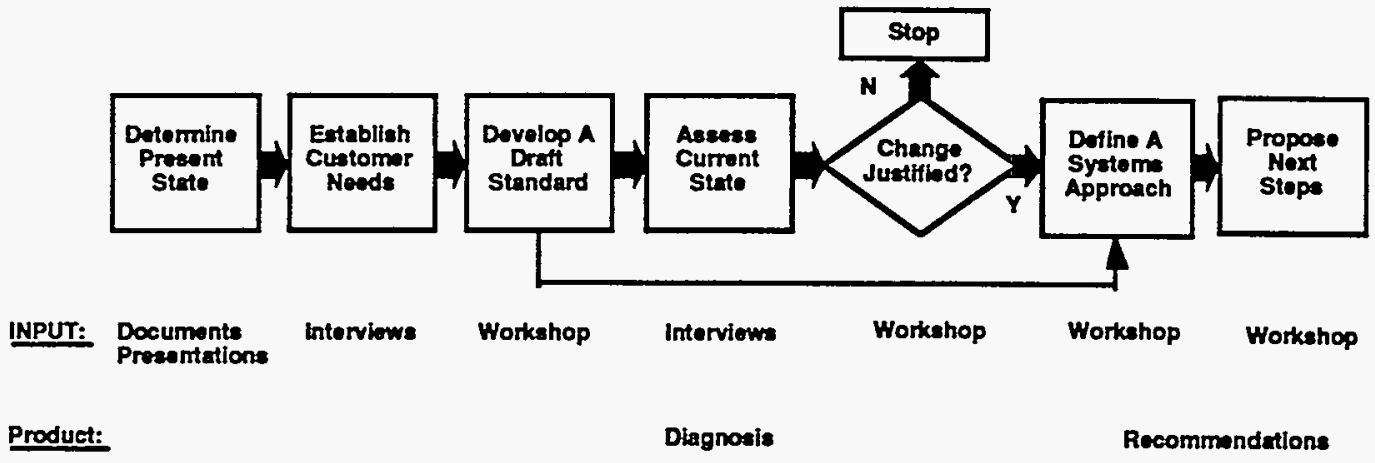

\section{A.2.2 Key Questions}

- What are the HR organization's products and services and how are they delivered?

- What products and services do customers want from HR and how do they want them delivered? What will they want in the near future?

- How does/will the commercial sector provide these products and services?

- How does/will the HR organization provide these products and services?

- What are the assets/strengths and barriers/weaknesses of the current HR processes with respect to customer needs and commercial practice?

- Is change appropriate based on the liabilities and benefits?

- If change is appropriate, how can the assets and strengths be used and the barriers and weaknesses be overcome to provide the required cost effective, quality HR products and services? 


\section{A.2.3 Interview Questions}

A.2.3.1 What are HR's products and services and how are they delivered?

Program Briefings

Full Team

Monday, August 15

Tuesday, August 16

- Who are the customers of HR?

- What is the mission and vision for HR?

- In its bid to DOE, what did Martin propose to do/change in HR?

- What are the current and planned HR products and services?

- Basic

- Value Added

- Who is responsible for each product or service?

- What are the customers' expectations of the products and services? How do you know?

- Are the customer's expectations being met? How do you know?

- How is the role of HR changing?

- What enables the organization's success?

- What inhibits it?

- What major changes are planned for HR products and services as well as corresponding processes? Why?

- How do you prioritize HR requirements?

A.2.3.2 What products and services do the HR customers want and how do they want them delivered? What will they want in the near future?
Customer Interviews Subteams per Section 4.5 on Wednesday, August 17

\section{ENABLING OUESTIONS}

- What business objectives are you trying to achieve in your activities?

- With respect to human resources, how are you doing it now?

- What difficulties and short comings are you facing?

PROCESS QUESTIONS

- What products and services do you want from HR?

- Basic

- Value Added

- What are your expectations of the products and services?

- How have you communicated your product and services needs and expectations?

- Are those expectations being met? 
- Has HR communicated an integrated plan to fulfill your product and service needs?

- Are your expectations of HR changing? What products and services will you want in the near future?

- How do you see reengineering changing your organization and your needs for HR?

- What are the product and service successes of the HR organization?

- What product and service improvements are required?

- If you were in charge, how would you change fulfillment of the HR processes.

\section{A.2.3.3 How does/will the commercial sector provide these products and services?}

A.2.3.4 How does/will the HR organization provide these products and services?
Full Team Meeting

Wednesday Evening

Program Interviews

Subteams Per Section 4.6

Thursday, August 18

Friday, August 19

\section{Overview}

- What product, service, or process do you own or contribute to?

- Is there a clear definition of the product or service specifications?

- Is the process to provide them written?

- Is there a clear product, service, or process owner?

- Who are the customers for the product or service?

- What are the customer's expectations of the product or service? How do you know?

- Are the customers' expectations being met? How do you know?

Cycle Time

- What is the cycle time in the process?

- Are there specific goals to improve the cycle time? Are they being met?

- How much rework is there in the process?

- Do defect rates exceed customer needs and expectations?

Flexibility

- Is there freedom of decision making in the process?

- Who makes the decisions?

- What types of decisions are made in the organization or function?

Change

- How do you see reengineering changing your products and services?

- What quick fixes would you make in your products, services, and processes to improve its quality or cost effectiveness?

- What fundamental changes would you make?

- What inhibits change in your work group? What foster change? 
$\underline{\text { Skills }}$

- Are skills employed effectively in the process?

- Are the needed skills present and deployed effectively?

- How are skills developed?

- What kind of training takes place to ensure appropriate skills levels?

Costs

- Is the process cost effective?

- What is the cost relative to the value added of its outputs?

- What is the relationship of rework, yield, capital utilization, and inventory?

Availability

- Is information available and communicated effectively to ensure process goals are met?

- Is it integrated and timely? Structured and flexible?

Relationships

- How does the process relate to other functions and processes?

- What are the dependencies?

- Is the process aided or inhibited by the current performance of related processes? How?

Measurement

- What are the process measurements?

- How is success defined and by whom for both the customers of the process and the process participants?

\section{Success}

- What are the critical success factors for the process?
A.2.3.5
What are the assets/strengths and barriers/ weaknesses of the current HR processes with respect to commercial practice and customer needs?
Full Team Meeting Thursday Evening

A.2.3.6 Is change appropriate based on the liabilities and benefits?

\section{liabilities and benefits?}

A.2.3.7 If change is appropriate, how can the assets and strengths be used and the barriers and weaknesses be overcome to provide the required cost effective, quality HR products and services?

Full Team Meeting
Friday Noon

RT Week 2

Workshop 


\section{A.2.4 Schedule}

\section{A.2.4.1 Week 1}

\begin{tabular}{|c|c|c|c|}
\hline$Y$ & TIME & ACTIVITY & ATION \\
\hline \multirow[t]{2}{*}{ Monday, 15th } & $7: 00 \mathrm{AM}-12: 30 \mathrm{PM}$ & Team Orientation Session & Hotel \\
\hline & 1:00 PM - 5:30 PM & \begin{tabular}{|l|} 
Program Presentations \\
\end{tabular} & DeLap \\
\hline \multirow[t]{2}{*}{ Tuesday, 16th } & 8:00 AM - 5:30 PM & Program Presentations & DeLap \\
\hline & 6:00 PM - 7:00 PM & Team Discussions & Hotel \\
\hline \multirow[t]{3}{*}{ Wednesday, 17th } & $8: 00 \mathrm{AM}-12: 00 \mathrm{PM}$ & \begin{tabular}{|l} 
Customer Interviews \\
\end{tabular} & Sandia \\
\hline & $1: 00 \mathrm{PM}-5: 00 \mathrm{PM}$ & $\begin{array}{l}\text { Customer/Program } \\
\text { Interviews } \\
\end{array}$ & Sandia \\
\hline & $6: 00 \mathrm{PM}-7: 30 \mathrm{PM}$ & Team Discussions & Hotel \\
\hline \multirow[t]{3}{*}{ Thursday, 18th } & $8: 00 \mathrm{AM}-12: 30 \mathrm{PM}$ & Program Interviews & Sandia \\
\hline & 1:00 PM - 5:00 PM & Program Interviews & Sandia \\
\hline & 6:00 PM - 9:00 PM & Team Discussions & Hotel \\
\hline \multirow[t]{4}{*}{ Friday, 19th } & $8: 00 \mathrm{AM}-11: 00 \mathrm{AM}$ & \begin{tabular}{|l} 
Program Interviews \\
\end{tabular} & Sandia \\
\hline & 11:00 AM - 12:00 PM & \begin{tabular}{|l} 
Information Systems \\
Presentation
\end{tabular} & Hotel \\
\hline & 12:00 PM - 2:00 PM & Team Discussions & Hotel \\
\hline & 2:00 PM & Depart For The Airport & \\
\hline
\end{tabular}

\section{A.2.4.2 Week 2}
DAY
TIME
ACTIVITY
LOCATION

\begin{tabular}{|l|l|l|l|}
\hline Monday, 29th & 8 AM to TBD & Team Workshop & Sandia \\
\hline Tuesday, 30th & 8 AM to TBD & Team Workshop & Sandia \\
\hline Wednesday, 31st & 8 AM to TBD & Team Workshop & Sandia \\
\hline Thursday, 1st & 8 AM to TBD & Team Workshop & Sandia \\
\hline Friday, 2nd & 8 AM to 2 PM & Team Workshop & Sandia \\
\hline & 2 PM & Depart for The Airport & \\
\hline
\end{tabular}




\section{A.2.4.3 Team Orientation Session- August 15}

TIME ACTIVITY
\begin{tabular}{|l|l|l|}
\hline 7:00 AM & Continental Breakfast & \\
\hline 7:30 AM & Introductions, Logistics & Weaver \\
\hline 8:00 AM & Review Charter and Schedule & Weaver \\
\hline 8:30 AM & $\begin{array}{l}\text { Customer's Perspective } \\
\text { Reengineering at Sandia }\end{array}$ & Wallace \\
\hline 9:00 AM & Red Team Process & Weaver \\
\hline 9:30 AM & Break & \\
\hline 10:00 AM & Training Video & Weaver \\
\hline 11:00 AM & Draft Review Plan & Weaver \\
\hline 12:00 AM & Working Lunch & \\
\hline 12:40 AM & Depart by Van For DeLaporte & \\
\hline
\end{tabular}

\section{A.2.4.4 Program Briefings - August 15 \& 16}

\section{DAY TIME}

\begin{tabular}{|l|l|l|l|}
\hline $\begin{array}{l}\text { Mon. } \\
\text { 15th }\end{array}$ & 1:00 PM & Welcome, Introductions & $\begin{array}{l}\text { C. Emery, VP HR } \\
\text { K. Carlson, DOE KAO } \\
\text { B. Harmeson, DOE KAO }\end{array}$ \\
\hline & $1: 30$ PM & Overview of HR & Charlie Emery, VP HR \\
\hline & $2: 00 \mathrm{PM}$ & Break & \\
\hline & $2: 15 \mathrm{PM}$ & Labor Relations & Julian Sanchez, Mgr. \\
\hline & $3: 15 \mathrm{PM}$ & Diversity/EEO & Berweida Learson, Mgr. \\
\hline & $4: 15 \mathrm{PM}$ & Additional Questions & HR Management \\
\hline & & & \\
\hline $\begin{array}{l}\text { Tue. } \\
\text { 16th }\end{array}$ & $8: 00 \mathrm{AM}$ & Opening & \\
\hline & $8: 30 \mathrm{AM}$ & Human Resources & Ralph Bonner, Dir. \\
\hline & $10: 30 \mathrm{AM}$ & Break & \\
\hline & $10: 45 \mathrm{AM}$ & Occupational Medicine & Larry Clevenger, Dir. \\
\hline & 12:00 PM & Lunch & \\
\hline & $1: 00 \mathrm{PM}$ & Educational Outreach & Bill Dawes, Mgr. \\
\hline & $2: 30 \mathrm{PM}$ & Break & \\
\hline & $2: 45 \mathrm{PM}$ & $\begin{array}{l}\text { Leadership \& Management } \\
\text { Development }\end{array}$ & JoAnn Romero, Mgr. \\
\hline & $3: 45 \mathrm{PM}$ & Additional Questions & HR Management \\
\hline & \multicolumn{2}{|}{} \\
\hline
\end{tabular}




\section{A.2.4.5 Customer Interviews- August 17}

\begin{tabular}{|c|c|c|c|c|c|}
\hline & $\begin{array}{l}\text { Subteam 1 } \\
\text { Bldg. 20245, RM. 101G } \\
\text { W. Bechdel, L. Crowe } \\
\text { D. Perry, T. Marts }\end{array}$ & $\begin{array}{l}\text { Subleam 2 } \\
\text { Bldg. 20245, RM. 101G } \\
\text { J. Brown, C. Richmond, } \\
\text { D. Weaver }\end{array}$ & $\begin{array}{l}\text { Subteam 3 } \\
\text { Bldg. 20245, Rm. 102IC } \\
\text { W. Brown, M. Murphy } \\
\text { B. Sexton, }\end{array}$ & $\begin{array}{l}\text { Subfeam } 4 \\
\text { Bldg. 20245, Rm. 102A } \\
\text { J. Boyle, H. Peebles } \\
\text { J. Trevisani }\end{array}$ & $\begin{array}{l}\text { Subteam 5 } \\
\text { Bldg. 20245, Rm. 102C } \\
\text { J. Doggette, C. Knightstep, } \\
\text { P. Thullen, C. Remington }\end{array}$ \\
\hline $8: 30 \mathrm{~A}$ & $\begin{array}{l}\text { Paul Shoemaker } \\
\text { Mgr. - Strategic Planning } \\
\text { Org. } 4514 / 4-6973\end{array}$ & $\begin{array}{l}\text { Frank Bacon } \\
\text { Mgr. - Neutron Generator } \\
\text { Dev. } \\
\text { Org. } 2561 / 4-3945 \\
\end{array}$ & $\begin{array}{l}\text { Karen Hart } \\
\text { DOE-AL HR } \\
\text { 5-4181 }\end{array}$ & $\begin{array}{l}\text { Dennis Miyoshi } \\
\text { Dir. - Nuclear Security } \\
\text { Systems } \\
\text { Org.5800 / 5-9926 }\end{array}$ & $\begin{array}{l}\text { Paul Rosenkoetter } \\
\text { Assistant Treasurer } \\
\text { Org. 10602 / 4-3964 }\end{array}$ \\
\hline $9: 30 \AA$ & $\begin{array}{l}\text { Sam Varnado } \\
\text { Dir. - Work for Others } \\
\text { Initiatives } \\
\text { Org. } 9900 / 5-9555\end{array}$ & $\begin{array}{l}\text { Virgil Dugan } \\
\text { Dir. of the executive staff } \\
\text { Org. } 12100 / 5-9064\end{array}$ & $\begin{array}{l}\text { Andy Boye } \\
\text { Mgr- Optics and } \\
\text { Exploratory Technologies } \\
\text { Org. 9925 5-8175 }\end{array}$ & $\begin{array}{l}\text { George Paul } \\
\text { Pres,, Metal Trades Union } \\
\text { 268-3242 }\end{array}$ & $\begin{array}{l}\text { John Stichman } \\
\text { Dir. - Surety Components \& } \\
\text { Instrumentation Center } \\
2600 / 5-9994\end{array}$ \\
\hline $10: 30 \mathrm{~A}$ & $\begin{array}{l}\text { Duane Carr } \\
\text { President, International } \\
\text { Guard Union of America } \\
265-7809\end{array}$ & $\begin{array}{l}\text { Dori Ellis } \\
\text { Dir. - WIPP \& Yucca Mt. } \\
\text { Programs } \\
\text { Org. } 6300 / 848-0780\end{array}$ & $\begin{array}{l}\text { Debbie Dominguez } \\
\text { Admin. Assistant, } \\
\text { Defense Prog. Ops Center } \\
\text { Org 12400 4-1984 }\end{array}$ & $\begin{array}{l}\text { Dona Crawford } \\
\text { Dir. - Scientific Comp } \\
\text { Org. } 1900 \text { / (510)294-2628 } \\
\text { (Wil Call in on 844-7736) }\end{array}$ & $\begin{array}{l}\text { lim Borders } \\
\text { Mgr. - Surface/Molecular } \\
\text { Analysis Dept. } \\
\text { Org. 1823 4-8855 }\end{array}$ \\
\hline $1: 00 \mathrm{P}$ & $\begin{array}{l}\text { Jim Martin } \\
\text { Dir. - Site Ops } \\
\text { Org. } 7300 / 5-9315\end{array}$ & $\begin{array}{l}\text { Ruth David } \\
\text { Dir. - Advanced Information } \\
\text { Technology } \\
\text { Org. 1090/ 5-9383 }\end{array}$ & \begin{tabular}{|l|} 
Larry Bertholf \\
Dir.-Reengineering \\
Org. $12400 / 271-7801$
\end{tabular} & $\begin{array}{l}\text { Paul Page } \\
\text { HR Reengineering Team } \\
\text { Org. } 5102 / 5-9782\end{array}$ & $\begin{array}{l}\text { Maureen Baca } \\
\text { Mgr. - Corp. Quality } \\
\text { Excellence Dept. } \\
\text { Org. } 12909 / 271-7927\end{array}$ \\
\hline $2: 00 \mathrm{P}$ & $\begin{array}{l}\text { Paul Heppner } \\
\text { Mgr. - CA Initiatives \& WFO } \\
\text { Org. } 8413 / \text { 294-2875 } \\
\text { (Will call in on 844-7736) } \\
\end{array}$ & $\begin{array}{l}\text { Linda Wilson } \\
\text { Admin. Assist. - Nuclear } \\
\text { Weapons Dev. Program } \\
\text { Org. } 5100 \text { / 4-8326 } \\
\end{array}$ & \begin{tabular}{|l|} 
Oohn Ledwith \\
Organizational \\
Effectiveness Consultant \\
Org. 2013 / 271-7920 \\
\end{tabular} & \begin{tabular}{|l} 
Dan Hartley \\
VP-Energy \& Env. \\
Org. 6000/5-9588 \\
(In 823/4016) \\
\end{tabular} & $\begin{array}{l}\text { Ed Graham } \\
\text { Dir. - Facility Ops \& Maint. } \\
\text { Org. } 7800 / 4-5555\end{array}$ \\
\hline $3: 00 \mathrm{P}$ & $\begin{array}{l}\text { Rich Marquez } \\
\text { DOE/AL Director of } \\
\text { Management \& Admin } \\
\text { 5-6036 }\end{array}$ & $\begin{array}{l}\text { lerry McDowell } \\
\text { Mgr. - Systems Design \& } \\
\text { Engineering Dept. I } \\
\text { Org. } 9811 \text { / 5-8747 }\end{array}$ & $\begin{array}{l}\text { Tom Hunter } \\
\text { Dir. - Energy \& Environment } \\
\text { Program Dev. } \\
\text { Org. } 6900 / 4-3763\end{array}$ & $\begin{array}{l}\text { Rochelle Lari (3:15p) } \\
\text { Personnel Rep. - Component } \\
\text { Dev. Division } \\
\text { Org. 2000/5-8969 } \\
\text { (Will Call in on 844-7736) }\end{array}$ & $\begin{array}{l}\text { Warren Cox } \\
\text { Mgr. - Env, Restoration } \\
\text { Project } \\
\text { Org. } 7581 \text { / 848-0411 }\end{array}$ \\
\hline $4: 00 \mathrm{P}$ & $\begin{array}{l}\text { William McLendon } \\
\text { President, Office and } \\
\text { Professional Employees } \\
\text { Union } \\
\text { 255-8101 }\end{array}$ & \begin{tabular}{|l} 
Kathleen Schulz \\
Mgr. - Environmental \\
Program Development \\
Org. 6605 / 5-9879
\end{tabular} & $\begin{array}{l}\text { John Krumm } \\
\text { SMTS New Hire since 1/94 } \\
\text { Org. 2111/ 5-5325 }\end{array}$ & $\begin{array}{l}\text { Ginger DeMarquez } \\
\text { SMTS New Hire 5/94 } \\
\text { Org. } 2472 / 4-7943\end{array}$ & $\begin{array}{l}\text { Dave Strip } \\
\text { Mgr. - Intelligent Systems } \\
\text { Principles Dept. } \\
\text { Org. } 2121 / 4-3962\end{array}$ \\
\hline $5: 00 \mathrm{P}$ & & 5 & & & \\
\hline
\end{tabular}




\section{A.2.4.6 Program Interviews - August 18}

A

\begin{tabular}{|l|l|}
\hline Ihursday & $\begin{array}{l}\text { Stratetic Direction } \\
\text { Integration/Comm. } \\
\text { HR Systems/Processes } \\
\text { (Sexton/Murphy } \\
\text { Peebles) }\end{array}$ \\
\hline 8-9 am & $\begin{array}{l}\text { Sheila Carr } \\
\text { Staff Member } \\
\text { Analyst } \\
\text { 4-2048 }\end{array}$ \\
\hline 9-10 am & $\begin{array}{l}\text { Ed Saucier } \\
\text { Mgr.-HR Info Systems Dept. } \\
\text { 5-8289 }\end{array}$ \\
\hline 10-11 am & $\begin{array}{l}\text { Danny Brown } \\
\text { Mgr.-HR Resources } \\
\text { Strategy Office } \\
5-8238\end{array}$ \\
\hline 1:30-2:30 pm & $\begin{array}{l}\text { Marge York } \\
\text { Mgr.-Personnel \& } \\
\text { Employee Resources Dept. } \\
\text { (510) 294-2242 }\end{array}$ \\
\hline 2:30-3:30 pm & $\begin{array}{l}\text { ulian Sanchez } \\
\text { Mgr.-Labor Relations } \\
\text { Dept. } \\
\text { 4-9249 }\end{array}$ \\
\hline 3:30-4:30 pm & $\begin{array}{l}\text { Char Seyfer } \\
\text { Mgr.-Corporate Education } \\
\text { Programs Dept. } \\
5-8990\end{array}$ \\
$\begin{array}{ll}\text { 4:30-5:30 pm } \\
\text { Marbara Jones } \\
\text { Agr.-Health Planning \& } \\
\text { 4-3843 }\end{array}$ \\
\hline
\end{tabular}

B

\begin{tabular}{|c|c|c|c|}
\hline $\begin{array}{l}\text { Educational O.R. } \\
\text { Personnel Dev. \& Training } \\
\text { O/D } \\
\text { (Doggette/Boyle/ } \\
\text { Richmond/Marts) }\end{array}$ & $\begin{array}{l}\text { Diversity } \\
\text { Staffing/Recruiting } \\
\text { Job Eval./Comp. } \\
\text { (J. Brown/Perry/ } \\
\text { Bechdel) }\end{array}$ & $\begin{array}{l}\text { Performance A\&M } \\
\text { Employee/Labor } \\
\text { Relations } \\
\text { EEO/AA } \\
\text { (W. Brown/Knightstep) }\end{array}$ & $\begin{array}{l}\text { Benefits } \\
\text { Health Programs } \\
\text { (Crowe/Remington } \\
\text { /Trevisani) }\end{array}$ \\
\hline $\begin{array}{l}\text { Ken Eckelmeyer } \\
\text { Staff Member } \\
\text { K-12 Program } \\
845-8680\end{array}$ & $\begin{array}{l}\text { Linda Lovato } \\
\text { Staff Member } \\
\text { Diversity Teams } \\
\text { 4-0268 }\end{array}$ & $\begin{array}{l}\text { Margaret Harvey } \\
\text { Mgr. - Performance } \\
\text { Assessment \& } \\
\text { Management } \\
5-9244\end{array}$ & $\begin{array}{l}\text { Carlos Griego } \\
\text { Mgr. - Pension, Life } \\
\text { Ins.\&Employee Svcs } \\
\text { Admin. Dept. } \\
4-2739\end{array}$ \\
\hline $\begin{array}{l}\text { Lorraine Herrera } \\
\text { Staff Member } \\
\text { Resource Center } \\
271-4100\end{array}$ & $\begin{array}{l}\text { Berweida Learson } \\
\text { Mgr.-Diversity Planning } \\
\text { Program } \\
5-8714\end{array}$ & $\begin{array}{l}\text { Danny Brown } \\
\text { Mgr.-HR Resources } \\
\text { Strategy Office } \\
5-8238\end{array}$ & $\begin{array}{l}\text { Sue Tenbroeck } \\
\text { Sickness Absence } \\
5-8469\end{array}$ \\
\hline $\begin{array}{l}\text { Sandra Barnes } \\
\text { Mgr.-Continuing Tech. } \\
\text { Education \& Training Dept. } \\
4-5070\end{array}$ & $\begin{array}{l}\text { Ashley McConnell } \\
\text { Staff Member } \\
\text { Analyst } \\
5-9115\end{array}$ & $\begin{array}{l}\text { Gwendolyn Germany } \\
\text { Staff Member } \\
\text { EEO/AA } \\
5-8715\end{array}$ & $\begin{array}{l}\text { Jane Farris } \\
\text { Staff Member } \\
\text { Pension Fund } \\
245-9365\end{array}$ \\
\hline $\begin{array}{l}\text { Edwina Kiro } \\
\text { Course Support Facilitator/ } \\
\text { Quality Education } \\
4-6455\end{array}$ & $\begin{array}{l}\text { Karen GIllings } \\
\text { Mgr. - Staff Initiatives } \\
\text { 5-0096 }\end{array}$ & $\begin{array}{l}\text { Linda Vigil-Lopez } \\
\text { Mgr.-EEO/AA } \\
4-4262\end{array}$ & $\begin{array}{l}\text { Bruce Criel } \\
\text { Staff Member } \\
\text { Pension Fund } \\
245-9355\end{array}$ \\
\hline $\begin{array}{l}\text { Elsa Glassman } \\
\text { Staff Member } \\
\text { Training Consultant } \\
4-4825\end{array}$ & $\begin{array}{l}\text { Marv Torneby } \\
\text { Mgr.-Staff Employment \& } \\
\text { Personnel Policy Dept. } \\
\text { 4-2965 }\end{array}$ & $\begin{array}{l}\text { Linda Bay-Chu } \\
\text { Staff Member } \\
\text { EEO/AA } \\
\text { 5-9914 }\end{array}$ & $\begin{array}{l}\text { Mark Biggs } \\
\text { Staff Member } \\
\text { Insurance } \\
4-1511\end{array}$ \\
\hline $\begin{array}{l}\text { To Ann Romero } \\
\text { Mgr.-Individual Development } \\
\text { Dept. } \\
245-9323\end{array}$ & $\begin{array}{l}\text { Shirley Emin } \\
\text { Staff Member } \\
\text { Coordinator } \\
5-9150\end{array}$ & $\begin{array}{l}\text { Julian Sanchez } \\
\text { Mgr.-Labor Relations } \\
\text { Dept. } \\
\text { 4-9249 }\end{array}$ & $\begin{array}{l}\text { Barbara Jones } \\
\text { Mgr.-Health Planning } \\
\text { \& Administration } \\
\text { Dept. } \\
4-3843\end{array}$ \\
\hline $\begin{array}{l}\text { Char Seyfer } \\
\text { Mgr.-Corporate Education } \\
\text { Programs Department } \\
\text { 5-8990 }\end{array}$ & $\begin{array}{l}\text { Becky McClaflin } \\
\text { Mgr. - Gen. Employment } \\
\text { \& Staffing Support Dept. } \\
4-3650\end{array}$ & $\begin{array}{l}\text { Yolanda Padilla-Vigil } \\
\text { Staff Member } \\
\text { Labor Relations } \\
\text { 4-4283 }\end{array}$ & $\begin{array}{l}\text { Jean Lopez } \\
\text { Staff Member } \\
\text { Workman's Comp. } \\
5-8134\end{array}$ \\
\hline
\end{tabular}


Program Interviews - August 19

A

B

C

D

E

\begin{tabular}{|c|c|c|c|c|c|}
\hline Eriday & $\begin{array}{l}\text { Stratetic Direction } \\
\text { Integration/Comm. } \\
\text { HR Systems/Processes } \\
\text { (Sexton/Murphy } \\
\text { Peebles) }\end{array}$ & $\begin{array}{l}\text { EducationalO.R. } \\
\text { Personnel Dev. \& Training } \\
\text { O/D } \\
\text { (Doggette/Boyle/ } \\
\text { Richmond/Marts) }\end{array}$ & $\begin{array}{l}\text { Diversity } \\
\text { Staffing/Recruiting } \\
\text { Job Eval./Comp. } \\
\text { (J. Brown/Perry/ } \\
\text { Bechdel) }\end{array}$ & $\begin{array}{l}\text { Performance A\&M } \\
\text { Employee/Labor } \\
\text { Relations } \\
\text { EEO/AA } \\
\text { (W. Brown/Knightstep) }\end{array}$ & $\begin{array}{l}\text { Benefits } \\
\text { Health Programs } \\
\text { (Crowe/Remington } \\
\text { /Trevisani) }\end{array}$ \\
\hline $8-9 \mathrm{am}$ & $\begin{array}{l}\text { Lisa Dunckel } \\
\text { Mgr.-Program Planning \& } \\
\text { Management Dept. } \\
\text { 5-8190 }\end{array}$ & $\begin{array}{l}\text { Patricia Salisbury } \\
\text { Staff Member } \\
\text { Sec/OAA } \\
889-2318\end{array}$ & $\begin{array}{l}\text { Ed Cassidy } \\
\text { Mgr.-Compensation \& } \\
\text { Job Evaluation Dept. } \\
\text { 5-8901 }\end{array}$ & $\begin{array}{l}\text { Tohn McAuliffe } \\
\text { Staff Member } \\
\text { Labor Relations } \\
4-9260\end{array}$ & $\begin{array}{l}\text { Linda Duffy } \\
\text { Mgr.-Preventative } \\
\text { Medicine/Employee } \\
\text { Assistance Dept. } \\
\text { 5-8015 }\end{array}$ \\
\hline $9-10 \mathrm{am}$ & $\begin{array}{l}\text { Ed Cassidy } \\
\text { Mgr.-Compensation \& Job } \\
\text { Evaluation Dept. } \\
\text { 5-8901 }\end{array}$ & $\begin{array}{l}\text { Jack Hueter } \\
\text { Staff Member } \\
\text { Individual Development } \\
5-8533\end{array}$ & $\begin{array}{l}\text { Bob Banks } \\
\text { Staff Member } \\
\text { Staff Recruiting } \\
4-4255\end{array}$ & $\begin{array}{l}\text { Tisa Dunckel } \\
\text { Mgr.-Program Planning } \\
\text { \&\& Management Dept. } \\
\text { 5-8190 }\end{array}$ & $\begin{array}{l}\text { Deborah Jensen } \\
\text { Staff Member } \\
\text { TLC Program } \\
\text { Coordinator } \\
\text { 5-9653 } \\
\end{array}$ \\
\hline $\begin{array}{l}10-11 \text { am } \\
\text { (schedule } \\
\text { only if } \\
\text { essential) }\end{array}$ & & & & & \\
\hline
\end{tabular}




\section{APPENDIX B}

\section{INFORMATION SOURCES}

\section{B.1 Documents}

HR/Doc. Cont. \#:

1. Charter for an Independent Review of the Sandia Human Resource Program, 7/94.

2. Strategic Plan 1994 (Draft for Comment), 6/94.

3. Review of Directors' Alliance (Labor Relations Conference), $4 / 1 / 93$.

4. Strategic Human Resources Plan, 10/93.

5. Education Outreach Department Information, 7/94.

6. Workforce Diversity Operational Plan AMCO Multi-Year Project Plan FY94-99, Case 4032 (Excerpt) (Draft 1), 7/15/94.

7. Diversity Leadership at Sandia National Laboratories (Revised Draft), 5/94.

8. Human Resources Division 3000 Org. Chart, 8/1/94.

9. OPEIU Union Agreement Booklet, 10/1/93.

10. Metal Trades Council Union Agreement Booklet, 10/1/93.

11. IGUA Local 27 Union Agreement Booklet, 12/1/93.

12. Strike Contingency Plan (UCAI - Must request access), 6/9/93.

13. Labor Relations 3010 Binder 1: Side Agreements/Strategy Plan, Mission \& Policy/Quality \& Process Plans/ Prog. \& Proj. Plans/Bulletin, no date.

14. Labor Relations Conference for Managers, 4/93.

15. Policy and Procedures Manual for the Employee Assistance Program, Morgan, H. and Price, A., 12/93.

16. Occupational Medicine Center Quality Plan, \#Med-16, 5/25/94.

17. Occupational Medicine ES\&H Program, \#PG470148, 3/26/91.

18. Policy \& Procedures Manual for the Total Life Concept (TLC) Program, Duffy, L. and Black, J., 10/30/92.

19. Occupational Medicine Center FY94 Plan, no date.

20. Diversity Leadership Center Business Plan for FY94 (Draft 1), 12/1/93.

21. Quality Plan Diversity Leadership Center - 3600, 10/93.

22. EEO/AA/Diversity Manual, 6/94.

23. Affirmative Action Program for Sandia National Laboratories, 1993-09/94.

24. Needed: Your Commitment to the Reengineering of Sandia Memo, Narath, A., to All Sandians, 5/26/94. 
25. Human Resources Corporate Processes (Owners/Experts), (Excerpt), 6/15/94.

26. LPR Strategic and Operational Planning, (Presentation to SQLC), Bertholf, L., 6/30/94.

27. Laboratory Process Reengineering Methodology, 6/30/94.

28. Scope of Diagnosis, Wallace, S., no date.

29. SNL LPR Approach, 7/19/94.

30. New Hire Packet, no date.

31. LPR Organizational Chart, 5/26/94.

32. LPR Strategy, (Presentation), Tegnelia, J., 6/16/94.

33. ADA Risk Assessment Project for Compensation \& Job Evaluation (Final Report \& Support Information), no date.

34. Sandia Salary Administration Binder, 8/13/93.

35. Job Evaluation Guidelines Binder, no date.

36. Campus Recruiter's Workshop Binder, no date.

37. Sandia Personnel Guide Binder, no date.

38. Performance Management Teaming for Excellence Binder, no date.

39. Standards \& Procedures Manual for ES\&H Training Dept., 10/92.

40. Human Resources Center - Education \& Training Binder, no date.

41. Human Resources Center - Campus Recruiting and Employment Binder (Partial), no date.

42. Human Resources Center - Benefits Binder (Part I), no date.

43. Human Resources Center - Benefits Binder (Part II), no date.

44. Human Resources Center - Binder (General), no date.

45. Reengineering at Sandia Presentation, Wallace, S., 8/15/94.

46. Changing to Performance-Based Management Contracting Table (Excerpt), no date.

47. Education Outreach Presentation to Red Team, 08/15/95.

48. Human Resources Presentation to Red Team, Bonner, R., $8 / 15 / 94$.

49. 8500 Human Resources Org. Chart (Livermore, CA), 7/18/94.

50. Chapter -- Implementation Process (Excerpt from Restructuring Report), no date.

51. Implementation Issues, Rosenkoetter, P., 9/20/91.

52. Personnel Actions Information, no date.

53. Corporate Information Systems Integration Process, no date.

54. Human Resources Information Systems 1994 Department Plan, no date.

55. Human Resources Information Systems Department Plan 1992, $12 / 92$.

56. Outcomes of SHRP Team Meeting Held 5/12/93, Memo, Brown, D. to Distribution, 5/17/93. 
57. HR Program Managers Council Agenda for Meeting on May 6, 1993, 5/6/93.

58. Strategic Human Resource Planning Team Agenda for Meeting on May 12, 1993, 5/12/93.

\section{B.2 Interviews/Meetings}

Name:

Baca, $M$.

Bacon, F.

Sandia Mgr. - Corp. Quality Excellence

Banks, B.

Sandia

Mgr. - Neutron Generator Dev.

Barnes, S.

Sandia

Staff Recruiting

Sandia

Bay-Chu, L.

Sandia

Mgr. - Continuing Tech. Education \& Training Dept.

Bertholf, L

Biggs, $M$.

Sandia

Sandia EEO/AA

Borders, J.

Sandia

Dir. - Reengineering

Insurance

Boye, A.

Sandia

Mgr. - Surface/Molecular Analysis

Brown, D.

Carr, D.

Carr, $\mathrm{S}$.

Cassidy, E.

Sandia

Sandia

Mgr. - Optics \& Exploratory Tech.

Mgr. - HR Resources Strategy Dept.

Sandia

President - IGUA

Sandia

Cox, W.

Crawford, D.

Criel, B.

Dawes, $W$.

DeMarquez, G.

Dominguez, D.

Duffy, L.

Dugan, $\mathrm{V}$.

Dunckel, L.

Sandia

Sandia

Sandia

Sandia

Sandia

HR Information Systems

Mgr. - Compensation \& Job

Evaluation Dept.

Mgr. - Envir. Restoration Project

Dir. - Livermore - Scientific Comp.

Pension Fund

Sandia

Mgr. - Education Outreach Dept.

Organic Materials

Sandia

Defense Prog. Operations

Mgr. - Preventative Medicine/

Employee Assistance Dept.

Sandia Dir. - Executive Staff

Sandia Mgr. - Program Planning \&

Management Dept.

Eckelmeyer, $\mathrm{K}$.

Ellis, D.

Emin, S.

Farris, J.

Germany, G.

Gillings, $\mathrm{K}$.

Glassman, E.

Graham, E.

Griego, C.

Sandia

Education Outreach Dept.

Sandia

Dir. - WIPP \& Yucca Mt. Programs

Sandia

Compensation \& Job Evaluation

Sandia

Pension Fund

Sandia EEO/AA

Sandia Mgr. - Staff Initiatives

Sandia ES\&G Training Consultant

Sandia

Dir. - Facility Ops. \& Maintenance

Sandia

Mgr. - Pension, Life Ins. \& Employee

Services Admin. Dept. 


\begin{tabular}{|c|c|c|}
\hline Hart, $\mathrm{K}$. & $\mathrm{DOE} / \mathrm{AL}$ & Human Resources \\
\hline Hartley, D. & Sandia & VP - Energy \& Environment \\
\hline Harvey, $\mathrm{M}$. & Sandia & Mgr. - Performance Assess. \& Mgt. \\
\hline Heppner, P. & Sandia & $\begin{array}{l}\text { Mgr. - Livermore - Initiatives \& } \\
\text { WFO }\end{array}$ \\
\hline Herrera, L. & Sandia & Resource Center \\
\hline Hueter, J. & Sandia & Individual Development \\
\hline Hunter, $\mathrm{T}$. & Sandia & Dir. - E \& E Sector Center \\
\hline Jensen, D. & Sandia & TLC Program Coordinator \\
\hline Jones, B. & Sandia & Mgr. - Health Planning \& Admin. \\
\hline Kiro, E. & Sandia & Continuing Tech. Education \\
\hline Krumm, J. & Sandia & Intelligent Sys. Sensors \& Controls \\
\hline Lari, $\mathrm{R}$. & Sandia & Personnel Representative \\
\hline Learson, $B$. & Sandia & Mgr. - Diversity Planning Program \\
\hline Lopez, J. & Sandia & Workman's Compensation \\
\hline Lovato, L. & Sandia & Diversity Planning Team \\
\hline Marquez, R. & DOE/AL & Dir. - Management \& Admin. \\
\hline Martin, J. & Sandia & Dir. - Site Operations \\
\hline McAuliffe, J. & Sandia & Labor Relations \\
\hline McClaflin, B. & Sandia & Mgr. - Gen. Employment \& Staffing \\
\hline McConnell, A. & Sandia & Compensation \& Job Evaluation \\
\hline McDowell, J. & Sandia & Mgr. - Sys. Design \& Engin. Dept. I \\
\hline McLendon, W. & Sandia & President - OPEIU \\
\hline Miyoshi, D. & Sandia & Dir. - Nuclear Security Systems \\
\hline Page, $P$. & Sandia & HR Reengineering Team \\
\hline Paul, G. & Sandia & President - Metal Trades Council \\
\hline Romero, J. & Sandia & Mgr. - Individual Development \\
\hline Rosenkoetter, P. & Sandia & Assistant Treasurer \\
\hline Sanchez, J. & Sandia & Mgr. - Labor Relations \\
\hline Saucier, E. & Sandia & Mgr. - HR Information Systems \\
\hline Schulz, K. & Sandia & Mgr. - Environmental Program Dev. \\
\hline Seyfer, C. & Sandia & Mgr. - Corporate Education Programs \\
\hline loemaker, $\mathrm{P}$. & Sandia & Mgr. - Strategic Planning \\
\hline $\operatorname{man}, \mathrm{J}$. & Sandia & Dir. - Surety Comp. \& Inst. Center \\
\hline & Sandia & $\begin{array}{l}\text { Mgr. - Intelligent Sys. Principles } \\
\text { Support. Dept. }\end{array}$ \\
\hline eck, & dia & Medical Admin./Sickness Absence \\
\hline & & $\begin{array}{l}\text { Mgr. - Staff Employment \& } \\
\text { Personnel Policy Dept. }\end{array}$ \\
\hline Varnado & San & Dir. - Work for Others Initiatives \\
\hline Lopez, L. & Sandia & Mgr. EEO/AA \\
\hline Wilson, L. & Sandia & Nuclear Weapons Dev. Progra \\
\hline Y & $\mathrm{Sa}$ & $\begin{array}{l}\text { Mgr. - Livermore Per. \& Employee } \\
\text { Resources Dept. }\end{array}$ \\
\hline
\end{tabular}




\section{APPENDIX C}

\section{ACTIVITY DIAGNOSIS}

In addition to the general HR Program diagnosis, described in Section 8 , the Red Team identified the following activity-specific assets and barriers.

\section{C1} Staffing and Recruiting .

\section{Assets}

Assets include well established and accepted processes for recruiting. These processes are carried out by well trained recruiters and empowered staff. In colleges that have been targeted for recruitment, active college relations programs are ongoing. The recognition of the need for a strategic staffing plan and a redeployment process to enable Sandia to fulfill its mission is also seen as an asset. In addition, Sandia's purchase of a commercial skills inventory package, Resumix, is also an asset.

\section{Barriers}

The Staffing and Recruiting Program lacks an integrated view of staffing: employment, skills development, redeployment, and separation. There are inconsistencies between policies and processes in California and New Mexico. A cultural commitment to lifelong employment continues in the face of a rapidly changing funding environment.

Recruiting has been focused on recent graduates who have done interesting research that can be related to something at the labs, rather than to fill specific business needs and positions. Although this approach has served Sandia well in the past, new business pressures may require recruitment of experienced professionals to meet changing business requirements.

The NM employment cycle time from interview to offer is long ( 6 to 8 weeks), although the California site has demonstrated it can make an offer in one day if the line manager has communicated the needed urgency. The cycle time and traditional recruiting methods may be preventing Sandia from recruiting the top candidates, including females and minorities. Referrals are routed through a slow, labor intensive paper process. The NM new hire orientation process is seen as cold and impersonal and not providing the HR information needed by new employees. Without an employee exit interview process, Sandia is missing a great opportunity for continuous improvement. Resumix is not yet used to track applicants.

$$
\text { C }-1
$$


Managers perceive their rewards and status to be tied to the size of their direct report staff. They are reluctant, therefore, to reduce their organization's size. The tight linkage between budgeted FTEs and organization on-roll targets is also a significant pressure for keeping FTEs within their own organizations.

With the current staffing equation, tightly controlled headcount ceilings and low attrition, the ability to build a staff with diverse skills is very limited. There is no process to address skills imbalance. Employee skill needs in a number of growth areas are being satisfied by contract employees. This trend may place Sandia's competitive advantage in jeopardy since the some critical skills exists primarily within the contracted work force. Top management's inability to commit to the implementation of a strategic staffing and redeployment process only adds to this dilemma. No one appears to be accountable for surplus or redeployed individuals.

\section{C.2 Lob Evaluation and Compensation}

\section{Assets}

The staff of the Compensation Department can be characterized as highly dedicated and well credentialed. They manage compensation and job evaluation programs which have many of the necessary components of successful processes.

\section{Barriers}

There is currently low management and customer satisfaction with both programs. Customer recognition and customer visibility are two primary barriers. The Compensation Department views DOE as its prime customer. When the Department speaks to the line managers, it is frequently through the Staffing Department rather than directly. The Department itself has very low visibility within Sandia.

The Compensation Department is more focused on preventing job evaluation escalation than a partnership role with line management. They manage an archaic administratively intensive job evaluation process, which is tightly held by the group. The Compensation Department devotes significant time and effort to this archaic process, apparently in pursuit of their self-assumed role as guardian of the taxpayer funds. This is noble but goes well beyond the intended purpose of any job evaluation process. The job 
evaluation process is slow and inflexible, yet there appears to be a strong desire by HR to expand this process to all technical positions.

Linkage between total compensation and performance is unclear at best. Considerable, broad confusion exists over non-base compensation. A non-base entitlement attitude is evident. This can be attributed to a lack of defined criteria and a lack of a link by management to a business strategy. Finally, there is no accountability for tieing performance management to improved performance.

\section{C.3 Diversity}

\section{Assets}

There is a strong desire by the Diversity staff to make a difference at Sandia. There is a commitment to cultivate an environment in which the staff feels free to discuss and/or initiate thoughts and ideas that are different and unique to the present way of doing business.

There is broad, active participation in the Diversity Program. The Program started with 40 participants in 1993 and has grown to 300 participants today. This program has reached across the organization to include such groups as the Work Force Diversity Council; Corporate Diversity Team; Diversity Action Teams, Diversity Champions and Partners and Outreach Committees.

The Program is receiving top level commitment and support from senior DOE officials such as Hazel O'Leary and Corlis Moody as well as the Sandia Executive Vice President, Jim Tegnelia.

\section{Barriers}

The acceptance of Diversity by the line managers as a value added Program is spotty at best within Sandia. The Diversity Program is apparently not well understood by a broad cross section of the Laboratories' staff. Sandia's staff generally views the Diversity Program as a flavor-of-themonth name for and as an extension of the Equal Employment Opportunity and Affirmative Action programs.

The purpose of the Diversity Program is not clearly defined within HR. In interviews with the HR staff, the Red Team heard differing views on the definition of diversity. This inconsistency with HR has probably contributed to the confusion with the Laboratories staff. HR personnel 
perceived their number one customer as the Secretary of Energy, Hazel O'Leary, not the line managers.

\section{C.4 Benefits and Health}

The Red Team's commercial best practices standard places a preference on cost effective outsourcing of most administrative functions, with a heavy use of available technology. There is a strong emphasis on communication, cost-sharing with development of flexible plans designed to increase employee responsibility in cost containment. Pension and retirement investment strategies are generally not performed in-house.

\section{Barriers}

While benefit plan designs meet or exceed the commercial standard, there is no clear, integrated corporate strategy for capitalizing on the benefits, health or work and family initiatives. Programs appear to be developed independent of a strategic plan or a total compensation philosophy. A strategic plan would allow development and analysis of programs aligned with the business plan and may help reduce the strong entitlement mentality that currently exists.

The cost of individual services and in-house administration are unknown in most areas. A cost/benefit analysis has not been performed for administrative services that could be outsourced. Programs are developed without identifying the additional cost burden or adequately defining cost savings. In-depth analysis would improve the cost/value equation.

There is no apparent tie between the Benefits Program, the Medical Program, or "total compensation." Cost savings and redundant benefits have not been analyzed because the health care plan system and occupational medicine systems are independent. Services provided by the occupational medicine clinic and the TLC program are not included in determining the cost of health care.

Technology utilization has not been focused to achieve reduced administrative and labor costs. There is not a communications plan to take advantage of current technology, such as the "Sandia Line," to gain greater employee awareness of the benefits programs. 
There are a myriad of training activities ongoing at the Laboratories to enhance knowledge, skills and abilities for a large number of employees.

\section{Barriers}

In many ways, the training at the Laboratory is a microcosm of the Sandia culture. That is, there are numerous redundancies and independent players, over twenty autonomous or semi-autonomous training units, a strong desire for local/programmatic control, an emphasis on well known or well credentialed programs, and loose or no accountability for costeffectiveness. The effort to change internal paradigms will be significant.

There is limited efficiency and effectiveness as there is not a unified training objective across the laboratories. Core competencies needed for each Division have not been identified. A process has not been developed to support "make-buy" decisions. Partnerships have not been developed with functional departments for the delivery of in-house programs. In the ES\&H area, for example, record keeping needs to be automated and owned by ES\&H. HR needs to support ES\&H with train-the-trainer and train-the-coursedeveloper workshops. The OE/OD capability has not focused on the specific areas each Division needs to deliver innovative, cost effective products and services.

While there is a high level of training activity, it seems to be more centered on personal preference choices than on competitive business strategy. Many students appear to attend classes because of a general subject matter interest A number of courses are offered because they are the latest fad or liked by someone who was exposed to the subject at a conference. There is little evidence of strategic business based curriculum development or coordination.

Although resource levels are high now, projected Sandia budget reductions may weaken the commitment to training. The current focus on personal-preference-training may have convinced management that "training doesn't make a valued difference in work performance." Both the casual observer and a studied reviewer of training effectiveness would be hard pressed to document R.O.I. for training resource expenditures. Under budget pressures training, as is frequently the case, could be the first to go. This would be unfortunate and risky given the new and increasing business demands quickly coming to bear on the Laboratory.

$$
\text { C }-5
$$




\section{Assets}

This is a well funded and generously supported program. The DOE appropriated budget for Sandia's Education Outreach Program is eleven million dollars. The program has an ample staff. The organization comprises approximately 23 Sandians, 13 contractors, and 7 students for a total of 43 individuals. About 15 of the Sandians are charged to institutional overhead.

The Red Team considered the Education Outreach Program to be one of the HR Program's assets. It has established a customer product focus, and has autonomy and direct control consistent with Sandia's culture. Many program elements provide outreach to various underrepresented groups.

\section{Barriers}

It was unclear to the Red Team if the education outreach program is cost effective. The program is extremely broad and diffuse. There is, on average, roughly one person per program, clearly an unusual situation that questions the efficacy of the overall program. There is little integration between and among the large number of program elements. Depending on the source material, some forty-two to forty-five individual programs or program elements are included among the responsibilities of the education outreach function. Several of these are based in California. Some programs, such as Adventures in Supercomputing, are managed and staffed from a line organization which rarely interacts with the education outreach staff.

Education outreach lacks the ability to use the full resources of the Internet and electronic communications to interact with schools, collaborators, and information sources. Their only electronic connection is a link to the Albuquerque Public Schools system.

Although education outreach has commissioned several program assessments, mostly in 1993, most customer feedback is anecdotal. Attention has not been devoted to incorporating evaluation procedures into program design. 
The Red Team's commercial best practice standard includes competency and behavior based performance management integrated with the employment life cycle.

\section{Assets}

The current performance management tool is consistent with commercial practice. Steps are being taken to improve communications between managers and employees.

\section{Barriers}

An integrated, cost effective performance management system linked to the business goals was not evident. The process owner is unclear and there is no accountability for the tieing performance management process to improved performance.

Sandia's lifetime employment philosophy inhibits the effective application of its performance management system. The performance management system is not addressing negative performance-performance at a level below total compensation. Expectations of increasing performance standards have not been communicated to the staff.

\section{C.8 Employee/Labor Relations}

The HR generalists and HR operations are functions that currently do not exist at Sandia. Therefore, there are no current assets nor current barriers to that activity. The current personnel representatives are not equivalent to and do not function as HR generalists.

\section{Assets}

Line management and labor relations agree that there is a good relationship with the Metal Trades Council and the International Guards of America.

There was excellent customer feedback about the Directors Alliance, a group of Directors that have a number of represented employees. They have provided strategic direction to labor relations. The Alliance has allowed labor relations to improve mutual understanding among line management, labor relations, and union employees. It has also helped line management to better understand the labor relations' issues. Additionally, $t$ 
the inclusion of two line managers on the negotiation's team for the last contract negotiations was given high marks by line management. It is generally agreed that labor relations is adequately staffed.

\section{Barriers}

Labor relations appears to have inadequate direction from senior management. When the Red Team questioned the interpretation of current labor relation metrics, it was unclear to labor relations management what the desired business strategy trend in the metrics should be.

The relationship with the Office and Professional Employees International Union is generally considered poor. Newly elected union representatives are leading an expansion effort. They are challenging subcontracting of work which appears to allow non-union, non-Sandia personnel to perform work viewed as similar to that performed by union employees. They are also attempting to organize functions that have not traditionally been represented. A prime driver for their actions appears to be a decline in union membership.

There is a mutually recognized need to improve communication between the labor relations department, line management, and the unions.

\section{C.9 EEO/AA}

In the Red Team's commercial business practices standard, HR solutions are provided within the framework of compliance and competitive advantage. Goals are expected to be met in all levels of the organization. Diversity is not linked to EEO/AA and is only possible when EEO/AA is an accomplished fact.

Assets

There is a large and dedicated staff and significant documentation regarding $\mathrm{EEO} / \mathrm{AA}$.

\section{Barriers}

EEO/AA goals are established irrespective of future staffing needs. Initiatives and accountability are not linked to clearly articulated Sandia strategies. EEO/AA has been thoroughly confused with diversity efforts; it may be difficult to decouple the two.

$$
\text { C }-8
$$


The staff resources in this area was considered as ample by the commercial Red Team members. 


\section{THIS PAGE \\ LEFT BLANK \\ INTENTIONALLY}

C -10 


\section{APPENDIX D}

COMMERCIAL BUSINESS EXAMPLES

OF

HR CORE-OPTIONAL

PRODUCTS AND SERVICES

D - 1 
THIS PAGE

LEFT BLANK

INTENTIONALLY

$$
\text { D - } 2
$$


D.1 Westinghouse Human Resources Survey

May 1993

D-3 


\section{THIS PAGE \\ LEFT BLANK \\ INTENTIONALLY}

D- 4 


\section{Please fill out the following information for statistical purposes.}

1) My Organization Unit Code is (please refer to the above page for code list).

2) My Departmental Unit is (check one)

_ General Human Resources

_ Compensation/Salary Administration Benefits

Communications EEO/AA

_Employment/Staffing

_Employee Relations/Labor Relations

_Training/Development

_Safety/Industrial Hygiene

_other

3) My Status is Full Time or Part Time (specify normal number of hours worked per week ).

4) My Level is (check one)

_ Administrative/Support

1st Level Management (Grade 34 - 39)

_ Professional

_ Middle Management (Grade 40 - 43)

_ Top Management (Grade 44 and above) 
Section I. Overall Instructions

Section II. Total Time Allocation

Section III. Survey of Services to Internal and External Customers

Section IV. Survey on Managing Your Own Staff (to be completed if you manage HR employees) 


\section{Purpose/Context}

- As you know, Westinghouse is in the midst of doing a complete review of a significant portion of its business. The Management Committee has assembled a "Transformation Team" to recommend structural and process changes that need to occur. Among many other initiatives, the commiltee identified the need to review the Human Resources function. A Human Resources sub-team (consisting of members from the function and their customers in line management) is now formed and underway.

- The Mission of the HR study team is to investigate and recommend structural and process changes to fundamentally change and improve the delivery of HR services within Westinghouse.

- We want our analysis to be fair and fact-based, and therefore need to ask a lot of questions...mostly on where you spend your time, and what you feel about the value and quality of the services you offer. Please help us make this analysis a success by filling out this survey as accurately as possible.

- This survey asks questions about human resources processes. Throughout this survey. You will be asked:

- What you feel to be the IMPORTANCE the processes have to your customers.

- What percentage of TIME you spend on these processes.

- What TYPE of activities you perform as you do these processes.

- What you feel to be the relative EFFECTIVENESS of these sub-processes to meet your customers' needs.

- This survey is part of a larger analysis (including customer interviews and internal reports) which investigates the efficiency, effectiveness, and importance of the HR processes.

- This response form is confidential. It will be used for the sole purpose of compiling a database after which it will be destroyed. Specific survey responses will not be disclosed. 
2. General Instructions

- Please read all instructions before starting each section of this survey.

- Be sure the survey materials are complete. You should have the following:

- The Survey Instructions (this document),

- A. The Main Process Survey Form, and

- B. The survey on Managing Your Own Staff (to be completed if you have management responsibility).

- Feel free to ask questions at any point in the survey administration process.

- Please note that this is not a test; there are no "right" or "wrong" answers.

3. After you have completed the process survey, please go back and check your work.

- Do all the percentages add up to $100 \%$ ?

- Do all the points add up to 100 points?

Thank you. 


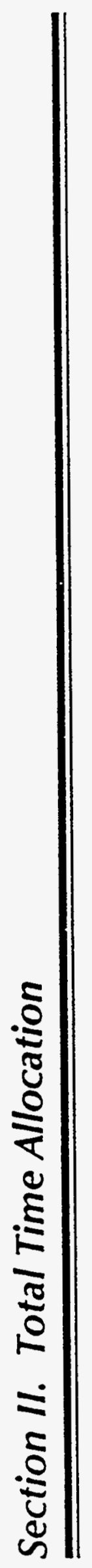


(NV) WESTINGHOUSE HUMAN RESOURCES PROCESS SURVEY

Please allocate $100 \%$ of your time among the following three categories. Make sure the percentages add to $100 \%$.

1. Services to internal and external customers (includes planning, delivering, adminitration, and supporting HR services).

2. Managing your own staff.

3. Miscellaneous (includes attending training, self development, and other miscellaneous activities). 
Section III. Survey of Services to Internal and External Customers 


\section{Staff the Organization}

(Manpower Planning, Headcount Reporting and Control, Preparing and Approving Requisitions, Internal Sourcing, External "On Demand" Recruitment Programs, Temporary Staff Sourcing, Reassignments, Employee Separations, Relocations)

\section{Train and Develop Employees}

(Career Development, Performance Management, Succession Planning, Management Development, Program and Technical Skills Training, Interpersonal Skills Training, Orientation)

\section{Compensating Employees}

Uob Evaluation and Classification, Salary Surveys/Competitive Analysis, Salary/Merit Plans, Alternative Compensation, Incentive Compensation, Executive Compensation, Expatriate Compensation)

\section{Benefiting Employees}

(Healthcare Management, Welfare Management, Attendance Management, Savings and Investment Plans/With or Without 401(k), Pension Management, Statutory Benefits)

5. Managing Employees/Labor Relations

(Non-Disciplinary Employee Counseling, Progressive Disciplinary Actions, Employee Communications, Collective Bargaining/Negotiating, Administering Bargaining Union Contracts, EEO/Affirmative Action, Recognition and Service Awards)

6. Strategic Business Planning

(Strategic Planning, People Management Strategic Planning, Organizational Effectiveness, Organizational Design)

7. Other

(Safety, Medical, Industrial Hygiene, Security/Facilities, Health Physics, Workplace Environmental Issues) 


\section{B. Sub-Process Survey Sheets}

- The general processes from the previous page have been further broken down into more detailed sub-processes. There is one page for each process. For each general process that you indicated time being spent, please complete the appropriate sub-process sheets. Leave all other sheets blank.

\section{- On each appropriate survey sheet, only fill in answers to questions on the sub-processes in which you spend time:}

\section{- EFFECTIVENESS}

\begin{tabular}{|c|c|c|c|c|c|c|}
\hline & Importinici: & \% & 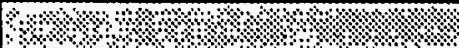 & Type of Acthtty $\$$ । & ৪ঃ & $\because$ \\
\hline $\begin{array}{l}\text { Effective- } \\
\text { ness }\end{array}$ & $\therefore$ Customot & $\begin{array}{l}\text { Yourt } \\
\text { Time }\end{array}$ & 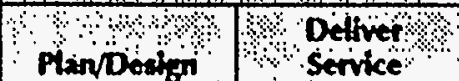 & Suppoit HAR: & Adininisters: & $\begin{array}{l}\text { Secretariall. } \\
\text { Clestcal }\end{array}$ \\
\hline
\end{tabular}

- Please rate how well each sub-process meets your customers' needs. Use the following scale:

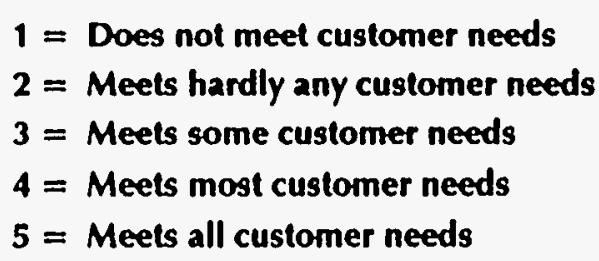

- IMPORTANCE

\begin{tabular}{|c|c|c|c|c|c|c|c|}
\hline & Imoortance & & $\because \cdots \quad \cdots \quad 4+3$ & Type of & ctivity. & \& & \\
\hline $\begin{array}{l}\text { Effective } \\
\text { nets }\end{array}$ & $\begin{array}{l}\text { to } \\
\text { Customer }\end{array}$ & अ Your & 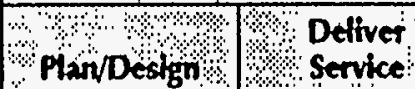 & Suppert H.R. & $\begin{array}{l}\text { Monitors/s/2 } \\
\text { Approvies }\end{array}$ & Admintsters & $\begin{array}{l}\text { Secretarial/ } \\
\text { Clerical }\end{array}$ \\
\hline
\end{tabular}

- Please spread 100 points to indicate your perception of the importance to each sub-process you perform. The more valuable the activity, the higher the point value you should assign to it. If you spend time in only one sub-process, all 100 points should be allocated to that sub-process. Make sure your points add up to 100 points. 


\section{B. Sub-Process Survey Sheets (cont'd)}

- Your TIME

\begin{tabular}{|c|c|c|c|c|c|c|c|c|}
\hline \multirow[b]{2}{*}{$\begin{array}{l}\text { Effective- } \\
\text { ness }\end{array}$} & \multirow{2}{*}{$\begin{array}{c}\text { Importance: } \\
\text { to } \\
\text { Customer }\end{array}$} & \multirow[b]{2}{*}{$\begin{array}{l}\text { Your } \\
\text { Time }\end{array}$} & \multicolumn{4}{|c|}{ yes of Acturity } & \multicolumn{2}{|l|}{$\because$} \\
\hline & & & Plan/Design: & $\begin{array}{l}\text { Delliver } \\
\text { Service }\end{array}$ & Support H.R. & $\begin{array}{l}\text { Mionitored } \\
\text { Approves }\end{array}$ & Admintsters & $\begin{array}{l}\text { Secreturial/ } \\
\text { Cerical }\end{array}$ \\
\hline
\end{tabular}

- Please spread 100 percent to indicate the relative amount of time you spend on each sub-process (i.e., if half of the time you spend in "Staff The Organization" is on "Manpower Planning," assign 50\% to it.) Make sure the percentages add up to $100 \%$

- TYPE of ACTIVITY

\begin{tabular}{|c|c|c|c|c|c|c|c|c|}
\hline \multirow{2}{*}{$\begin{array}{c}\text { Effective- } \\
\text { ness }\end{array}$} & \multirow{2}{*}{$\begin{array}{c}\text { Importance } \\
\text { to } \\
\text { Customer }\end{array}$} & \multirow{2}{*}{$\begin{array}{l}{ }_{\text {Your }} \\
\text { Time }\end{array}$} & \multicolumn{6}{|c|}{ Type of Activity } \\
\hline & & & Fan/Design & $\begin{array}{l}\text { Deliver } \\
\text { Service }\end{array}$ & Support H.R. & $\begin{array}{l}\text { Monitors/ } \\
\text { Approver }\end{array}$ & Administers & $\begin{array}{l}\text { Secretariall } \\
\text { Cerical }\end{array}$ \\
\hline
\end{tabular}

- Think of the time you spend doing a sub-process. Please spread $100 \%$ across the activities. If you do not perform an activity, leave it blank.

- Definition of activities:

- Plan/Design: Refers to all types of planning, designing, and strategizing required to conduct the sub-processes. Includes time spent researching and analyzing.

- Deliver Service: Refers to all types of direct contact with customers (employees, managers, and external agencies) in delivery of your H.R. services.

- Support H.R.: Includes all activities for serving/supporting H.R. colleagues (i.e., specialist knowledge supplied to generalists).

- Monitors/Approves: Includes time spent reviewing forms and processes for accuracy/policy, etc.

- Administers: Includes all Administration, Coordination, Arranging, and Scheduling required to deliver H.R. services.

- Secretarial/Clerical: Refers to time required to manually fill in forms, input data, type, file, answer phones, etc. 
(스 WESTINGHOUSE HUMAN RESOURCES PROCESS SURVEY

\begin{tabular}{|c|c|c|c|c|c|c|c|c|c|c|}
\hline \multirow{2}{*}{\multicolumn{2}{|c|}{ Process }} & \multirow[b]{2}{*}{$\begin{array}{c}\text { EHective- } \\
\text { ness }\end{array}$} & \multirow{2}{*}{$\begin{array}{c}\text { Importance } \\
\text { to } \\
\text { Customer }\end{array}$} & \multirow[b]{2}{*}{$\begin{array}{l}\text { Your } \\
\text { Time }\end{array}$} & \multicolumn{6}{|c|}{ Type of Aclivity } \\
\hline & & & & & $\begin{array}{c}\text { Plan/ } \\
\text { Dosign }\end{array}$ & $\begin{array}{l}\text { Toliver } \\
\text { | Service| }\end{array}$ & $\begin{array}{l}\text { Support } \\
\text { H.R. }\end{array}$ & $\begin{array}{l}\text { TMonitors/ } \\
\text { |Approves | }\end{array}$ & Administers | & $\begin{array}{l}\text { Tocrotarial/ } \\
\text { S Clerical }\end{array}$ \\
\hline \multicolumn{2}{|c|}{ 1. Staff the Organization } & $\because$. & & & & & & & $\cdot$ & \\
\hline 1.1 & $\begin{array}{l}\text { Manpower Planning: Includes capacity requirement planning, and other } \\
\text { activities that are included in planning where people are going, what } \\
\text { people are needed, and what adjustments are needed to current } \\
\text { manpower, including expatriate counseling, etc. }\end{array}$ & & & & & & & & & 1 \\
\hline 1.2 & $\begin{array}{l}\text { Headcount Reporting and Control: Includes all activities performed in } \\
\text { the headcount reporting process, maintaining organization charts, } \\
\text { telephone directories, personnel lists, PRISM forms. }\end{array}$ & & & & & 1 & & 1 & 1 & 1 \\
\hline 1.3 & $\begin{array}{l}\text { Preparing and Approving Requisitions: Includes all activitles performed } \\
\text { in preparing and obtaining approval for requisitions for full time } \\
\text { employees and temporary employees. }\end{array}$ & & & & & 1 & & 1 & 1 & 1 \\
\hline 1.4 & $\begin{array}{l}\text { Internal Sourcing: Includes all activities performed in obtaining people } \\
\text { through internal sources such as posting, interviewing, transferring, } \\
\text { promotions, career opportunity bulletin, etc. }\end{array}$ & & & & & $\begin{array}{l}1 \\
\perp\end{array}$ & & 1 & 1 & 1 \\
\hline 1.5 & $\begin{array}{l}\text { External "On-Demand" Recruitment: Includes activities performed in } \\
\text { obtaining people with special skills, l.e., the special purpose recruitment, } \\
\text { such as sourcing, tracking applicants, advertising, interviewing, selecting, } \\
\text { hiring, etc. Does not include college recruitment programs and } \\
\text { contractors/temps. }\end{array}$ & & & & & & & $\begin{array}{l}1 \\
1 \\
1 \\
1\end{array}$ & $\begin{array}{c}1 \\
1 \\
1 \\
1\end{array}$ & $\begin{array}{l}1 \\
1 \\
1 \\
1\end{array}$ \\
\hline 1.6 & $\begin{array}{l}\text { Recruitment Programs: Includes activities related to obtaining people } \\
\text { through special recruitment programs (i.e., college, summer intern, } \\
\text { co-ops) such as forecasting, scheduling, interviewing, selecting, hiring, } \\
\text { Engineering Manufacturing Professional Development Program, Human } \\
\text { Resources Development Program. }\end{array}$ & & & & & $\begin{array}{l}1 \\
1 \\
1\end{array}$ & & $\begin{array}{l}1 \\
1 \\
1\end{array}$ & $\begin{array}{l}1 \\
1 \\
1\end{array}$ & $\begin{array}{l}1 \\
1 \\
1\end{array}$ \\
\hline 1.7 & $\begin{array}{l}\text { Temporary Staff Sourcing: Includes all activities related to obtaining } \\
\text { temporary staff such as temps, contractors, part-time employees. }\end{array}$ & & & & & | & & 1 & 1 & 1 \\
\hline & $\begin{array}{l}\text { Reassignments: Includes all activities related to reassigning employees or } \\
\text { placing them on temporary assignment within their own location or } \\
\text { division due to an oversupply of resources, reorganizations, temporary } \\
\text { assignments, restructuring, factory personnel shuffling, etc. }\end{array}$ & & & & & 1 & & $\begin{array}{l}1 \\
1\end{array}$ & 1 & 1 \\
\hline 1.9 & $\begin{array}{l}\text { Employment Separations: Includes activities related to separating } \\
\text { employees from Westinghouse or from their division. The activities } \\
\text { include severance continuations, exit interviews, layoffs/shurdowns, } \\
\text { deaths, outplacement, etc. }\end{array}$ & & & & & & & 1 & & 1 \\
\hline 1.10 & $\begin{array}{l}\text { Relocations: Includes activities related to physically moving employees, } \\
\text { their families and properties. }\end{array}$ & & & & & & & & & 1 \\
\hline & TOTAL & & 100 Points & 00 & & & & & & \\
\hline
\end{tabular}




\begin{tabular}{|c|c|c|c|c|c|c|c|c|c|c|}
\hline \multirow{2}{*}{\multicolumn{2}{|c|}{ Process }} & \multirow[b]{2}{*}{$\begin{array}{c}\text { EHective- } \\
\text { ness }\end{array}$} & \multirow{2}{*}{$\begin{array}{c}\text { Importance } \\
10 \\
\text { Customer }\end{array}$} & \multirow[b]{2}{*}{$\begin{array}{l}\text { Your } \\
\text { Time }\end{array}$} & \multicolumn{6}{|c|}{ Type of Activity } \\
\hline & & & & & $\begin{array}{l}\text { Plan/ } \\
\text { Design }\end{array}$ & $\begin{array}{l}\text { Tolliver } \\
\text { | Service| }\end{array}$ & $\begin{array}{l}\text { Support } \\
\text { H.A. }\end{array}$ & $\begin{array}{l}\text { Monitors/ } \\
\text { |Approves | }\end{array}$ & Administers & $\begin{array}{l}\text { Secretarial/ } \\
\text { Clerical }\end{array}$ \\
\hline \multicolumn{2}{|c|}{ 2. Train and Develop Employees } & & & $\therefore$ & & & & & & $\because$ \\
\hline 2.1 & $\begin{array}{l}\text { Career Development: Includes activities such as coaching, counseling, } \\
\text { advising, mentoring, etc. }\end{array}$ & & & & & $\begin{array}{l}1 \\
1 \\
1\end{array}$ & & $\begin{array}{l}1 \\
1 \\
1\end{array}$ & & $\begin{array}{l}1 \\
1 \\
1\end{array}$ \\
\hline 2.2 & $\begin{array}{l}\text { Performance Management: Includes activities relating to assessing } \\
\text { personnel, setting objectives, appraising performance, etc. }\end{array}$ & & & & & 1 & & $\begin{array}{l}1 \\
1 \\
1\end{array}$ & & $\begin{array}{l}1 \\
1 \\
1\end{array}$ \\
\hline 2.3 & $\begin{array}{l}\text { Succession Planning: Includes activities related to identifying and } \\
\text { developing high potential candidates, including cross functional } \\
\text { assignments and construction/maintenance of data base/data book. }\end{array}$ & & & & & $\begin{array}{c}1 \\
1 \\
1 \\
1\end{array}$ & & $\begin{array}{c}1 \\
1 \\
1 \\
1\end{array}$ & $\begin{array}{l}5 \\
1 \\
1 \\
1\end{array}$ & $\begin{array}{c}T \\
1 \\
1\end{array}$ \\
\hline 2.4 & $\begin{array}{l}\text { Management Development: Includes activities related to training, } \\
\text { education and awareness of supervisory and management personnel- } \\
\text { including the assessment center activity. }\end{array}$ & & & & & $\begin{array}{l}1 \\
1 \\
1 \\
1\end{array}$ & & 1 & & 1 \\
\hline 2.5 & $\begin{array}{l}\text { Program and Technical Skills Training: Includes activities related to the } \\
\text { training of technical skills to participants and employees. }\end{array}$ & & & & & $\begin{array}{l}1 \\
1 \\
1\end{array}$ & $\begin{array}{l}1 \\
1 \\
1\end{array}$ & 1 & i & $\begin{array}{l}1 \\
1 \\
1\end{array}$ \\
\hline 2.6 & $\begin{array}{l}\text { Interpersonal Skills Training: Includes activities related to developing } \\
\text { interpersonal skills for employees such as team building, human relations, } \\
\text { effective communications, personal effectiveness, etc. }\end{array}$ & & & & & $\begin{array}{l}1 \\
1 \\
1 \\
1\end{array}$ & $\begin{array}{l} \\
1 \\
1 \\
1\end{array}$ & $\begin{array}{l}1 \\
1 \\
1 \\
1\end{array}$ & $\begin{array}{l}1 \\
1 \\
1 \\
1\end{array}$ & $\begin{array}{l}1 \\
1 \\
1 \\
1\end{array}$ \\
\hline 2.7 & $\begin{array}{l}\text { Orientation: Includes activities related to training employees to be able } \\
\text { to perform a new assignment, such as information on benefits, work rules, } \\
\text { product knowledge, contribution to business purpose, ethics, code of } \\
\text { conduct, safety, quality, etc. }\end{array}$ & & & & & $\begin{array}{l}1 \\
1 \\
1 \\
1 \\
1\end{array}$ & $\begin{array}{l}+ \\
1 \\
1 \\
1 \\
1\end{array}$ & $\begin{array}{l}T \\
1 \\
1 \\
1 \\
1\end{array}$ & $\begin{array}{l}1 \\
1 \\
1 \\
1 \\
1\end{array}$ & $\begin{array}{l}1 \\
1 \\
1 \\
1 \\
1\end{array}$ \\
\hline & TOTAL & $\gamma^{\circ}$ & 100 Points & $100 \%$ & & & ; & $\%$ & & \\
\hline
\end{tabular}


(Nㅏㄴ WESTINGHOUSE HUMAN RESOURCES PROCESS SURVEY

\begin{tabular}{|c|c|c|c|c|c|c|c|c|c|c|}
\hline \multirow{2}{*}{\multicolumn{2}{|c|}{ Process }} & \multirow[b]{2}{*}{$\begin{array}{c}\text { EHective. } \\
\text { ness }\end{array}$} & \multirow{2}{*}{$\begin{array}{c}\text { Importance } \\
\text { to } \\
\text { Customer }\end{array}$} & \multirow[b]{2}{*}{$\begin{array}{l}\text { Your } \\
\text { Time }\end{array}$} & \multicolumn{6}{|c|}{ Type of Activity } \\
\hline & & & & & \begin{tabular}{|l|l|} 
Plan/ \\
Design |
\end{tabular} & \begin{tabular}{|l|} 
Dellver \\
| Servicel
\end{tabular} & $\begin{array}{l}\text { Support } \\
\text { H.R. }\end{array}$ & $\begin{array}{l}\text { TMonilors/ } \\
\text { | Approves }\end{array}$ & $\begin{array}{r}\vdots \\
\mid \text { Administäs }\end{array}$ & $\begin{array}{l}\text { Tecretarial/ } \\
\text { Clerical }\end{array}$ \\
\hline \multicolumn{2}{|c|}{ 3. Compensating Employees } & & & & & & & & $:$ & $8 \%$ \\
\hline & $\begin{array}{l}\text { Job Evaluation and Classification: Includes activities related to } \\
\text { evaluating and classifying jobs. }\end{array}$ & & & & $\begin{array}{l}1 \\
1 \\
1\end{array}$ & $\begin{array}{l}1 \\
1 \\
1\end{array}$ & & $\begin{array}{l}1 \\
1 \\
1\end{array}$ & $\begin{array}{l}1 \\
1 \\
1\end{array}$ & $\begin{array}{l}1 \\
1 \\
1\end{array}$ \\
\hline 3.2 & $\begin{array}{l}\text { Salary Surveys/Competitive Analysis: Includes activities related to salary } \\
\text { surveys and competitive analysis. }\end{array}$ & & & & 1 & $\begin{array}{l}\Gamma \\
1 \\
1 \\
1\end{array}$ & & $\begin{array}{l}1 \\
1 \\
1 \\
1\end{array}$ & $\begin{array}{l}1 \\
1 \\
1 \\
1\end{array}$ & $\begin{array}{l}1 \\
1 \\
1 \\
1\end{array}$ \\
\hline & $\begin{array}{l}\text { Salary/Merit Plans: Includes activities such as budgeting, merit planning, } \\
\text { presentations and approval analysis. }\end{array}$ & & & & & $\begin{array}{l}1 \\
1 \\
1\end{array}$ & & $\begin{array}{l}1 \\
1 \\
1\end{array}$ & $\begin{array}{l}1 \\
1 \\
1\end{array}$ & $\begin{array}{l}1 \\
1 \\
1\end{array}$ \\
\hline 3.4 & $\begin{array}{l}\text { Alternative Compensation: Includes activities related to broad based, } \\
\text { short-term incentive plans such as profit sharing, gain sharing, project } \\
\text { related and/or team based. }\end{array}$ & & & & & $\begin{array}{c}1 \\
1 \\
1\end{array}$ & 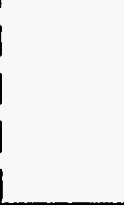 & $\begin{array}{l}1 \\
1 \\
1 \\
1\end{array}$ & $\begin{array}{l}1 \\
1 \\
1 \\
1\end{array}$ & $\begin{array}{l}1 \\
1 \\
1 \\
1\end{array}$ \\
\hline 3.5 & $\begin{array}{l}\text { Incentive Compensation: Includes activities related to narrowly focused, } \\
\text { short-term incentive plans such as sales, special performance awards, } \\
\text { other special awards, stock-based awards, etc. }\end{array}$ & & & & & $\begin{array}{l}1 \\
1 \\
1 \\
1\end{array}$ & 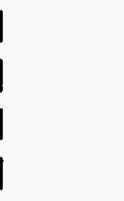 & $\begin{array}{l}1 \\
1 \\
1 \\
1\end{array}$ & $\begin{array}{l}1 \\
1 \\
1 \\
1\end{array}$ & $\begin{array}{l}1 \\
1 \\
1 \\
1\end{array}$ \\
\hline 3.6 & $\begin{array}{l}\text { Executive Compensation: Includes activities related to long-term } \\
\text { incentives for executives and executive benefits programs (such as } \\
\text { executive pensions). }\end{array}$ & & & & & $\begin{array}{l}1 \\
1 \\
1 \\
1\end{array}$ & 1 & $\begin{array}{l}1 \\
1 \\
1\end{array}$ & $\begin{array}{l}1 \\
1 \\
1 \\
1\end{array}$ & $\begin{array}{l}1 \\
1 \\
1 \\
1\end{array}$ \\
\hline 3.7 & $\begin{array}{l}\text { Expatriate Compensation: Includes activities relating to compensating } \\
\text { expatriates. }\end{array}$ & & & & & $\begin{array}{l}1 \\
1 \\
1\end{array}$ & & 1 & $\begin{array}{l}1 \\
1 \\
1\end{array}$ & 1 \\
\hline & TOTAL & & 100 Points & $100 \%$ & & & & & & \\
\hline
\end{tabular}




\begin{tabular}{|c|c|c|c|c|c|c|c|c|c|}
\hline \multirow{2}{*}{\multicolumn{2}{|c|}{ Process }} & \multirow[b]{2}{*}{$\begin{array}{c}\text { Effective } \\
\text { ness }\end{array}$} & \multirow{2}{*}{$\begin{array}{c}\text { Importance } \\
\text { to } \\
\text { Customer }\end{array}$} & \multirow[b]{2}{*}{$\begin{array}{l}\text { Your } \\
\text { Time }\end{array}$} & \multicolumn{5}{|c|}{ Type of Activity } \\
\hline & & & & & $\begin{array}{l}\text { Plan/ Dellver } \\
\text { Design | Service| }\end{array}$ & $\begin{array}{c}\text { Support } \\
\text { H.R. }\end{array}$ & $\begin{array}{l}\text { Monitors/ } \\
\text { |Approves }\end{array}$ & Administers & $\begin{array}{l}\text { Secretarial/ } \\
\text { 31 Clerical }\end{array}$ \\
\hline \multicolumn{2}{|c|}{ 4. Benefiting Employees } & & & $\because$ & & & & & a \\
\hline 4.1 & $\begin{array}{l}\text { Healthcare Management: Includes activities related to developing or } \\
\text { managing the healthcare of employees such as medical plans, dental plans. }\end{array}$ & & & & $\begin{array}{l}1 \\
1 \\
1\end{array}$ & & $\begin{array}{l}1 \\
1 \\
1\end{array}$ & $\begin{array}{l}1 \\
1 \\
1\end{array}$ & $\begin{array}{l}1 \\
1 \\
1\end{array}$ \\
\hline 4.2 & $\begin{array}{l}\text { Welfare Management: Includes activities related to managing the welfare } \\
\text { of employees such as Insurance, Short Term Disability (STD), Long Term } \\
\text { Disability (LTD), etc. }\end{array}$ & & & & 1 & & $\begin{array}{l}1 \\
1 \\
1 \\
1\end{array}$ & $\begin{array}{l}1 \\
1 \\
1\end{array}$ & $\begin{array}{l}1 \\
1 \\
1 \\
1\end{array}$ \\
\hline 4.3 & $\begin{array}{l}\text { Attendance Management: Includes activities related to employee time-off } \\
\text { with and without pay, such as jury duty, compensatory time, illness, } \\
\text { vacation, holidays, disabilities and activities related to managing } \\
\text { employees back into the workforce. }\end{array}$ & & & & $\begin{array}{l}1 \\
1 \\
1 \\
1 \\
1 \\
1\end{array}$ & 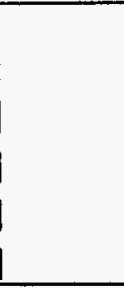 & $\begin{array}{c}1 \\
1 \\
1 \\
1 \\
1 \\
1\end{array}$ & $\begin{array}{l}1 \\
1 \\
1 \\
1 \\
1 \\
1\end{array}$ & $\begin{array}{l}T \\
1 \\
1 \\
1 \\
1 \\
1\end{array}$ \\
\hline 4.4 & $\begin{array}{l}\text { Savings and Investment Plans/With or Without } 401(k) \text { : Westinghouse } \\
\text { Stock Plan, Credit Unions, bonds, etc. }\end{array}$ & & & & $\begin{array}{l}1 \\
1 \\
1 \\
1\end{array}$ & I & $\begin{array}{l}1 \\
1 \\
1 \\
1\end{array}$ & $\begin{array}{l}1 \\
1 \\
1 \\
1\end{array}$ & $\begin{array}{l}1 \\
1 \\
1 \\
1\end{array}$ \\
\hline 4.5 & $\begin{array}{l}\text { Pension Management: Includes activities related to supporting the } \\
\text { retirement process and preparation for retirement, i.e., financial planning, } \\
\text { advice, counsel, elections, plan development. }\end{array}$ & & & & $\begin{array}{l}1 \\
1 \\
1 \\
1 \\
1\end{array}$ & $\begin{array}{l}1 \\
1 \\
1 \\
1\end{array}$ & $\begin{array}{l}1 \\
1 \\
1 \\
1 \\
1\end{array}$ & $\begin{array}{l}1 \\
1 \\
1 \\
1 \\
1\end{array}$ & $\begin{array}{l}1 \\
1 \\
1 \\
1 \\
1\end{array}$ \\
\hline 4.6 & $\begin{array}{l}\text { Statutory Benefits: Includes activities related to workers' compensation, } \\
\text { unemployment compensation. }\end{array}$ & & & & $\begin{array}{l}1 \\
1 \\
1 \\
1\end{array}$ & $\begin{array}{l}1 \\
1 \\
1\end{array}$ & $\begin{array}{l}1 \\
1 \\
1 \\
1\end{array}$ & $\begin{array}{l}1 \\
1 \\
1\end{array}$ & $\begin{array}{l}1 \\
1 \\
1 \\
1\end{array}$ \\
\hline & TOTAL & 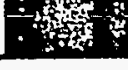 & 100 Points & $100 \%$ & & 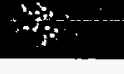 & & & \\
\hline
\end{tabular}


(12) WESTINGHOUSE HUMAN RESOURCES PROCESS SURVEY

\begin{tabular}{|c|c|c|c|c|c|c|c|c|c|c|}
\hline \multirow{2}{*}{\multicolumn{2}{|c|}{ Process }} & \multirow[b]{2}{*}{$\begin{array}{c}\text { EHractive. } \\
\text { ness }\end{array}$} & \multirow{2}{*}{$\begin{array}{l}\text { Importance } \\
\text { to } \\
\text { Customer }\end{array}$} & \multirow[b]{2}{*}{$\begin{array}{l}\text { Your } \\
\text { Time }\end{array}$} & \multicolumn{6}{|c|}{ Type of Aclivity } \\
\hline & & & & & $\begin{array}{l}\text { Plan/ } \\
\text { Design }\end{array}$ & $\begin{array}{l}\text { TDelliver } \\
\text { | Service| }\end{array}$ & $\begin{array}{l}\text { Support } \\
\text { H.R. }\end{array}$ & $\begin{array}{l}\text { Monitors/ } \\
\text { | Approves | }\end{array}$ & Administers | & $\begin{array}{l}\text { Secretarial/ } \\
\text { s| Clerical }\end{array}$ \\
\hline \multicolumn{2}{|c|}{ 5. Managing Employee/Labor Relations } & & & & & & & & & 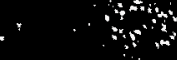 \\
\hline 5.1 & $\begin{array}{l}\text { Non-Disciplinary Employee Counseling: Includes activities related to } \\
\text { responding to employee questions and concerns, referring employees to } \\
\text { the Employee Assistance Program (EAP), etc. }\end{array}$ & & & & & 1 & & & 1 & 1 \\
\hline 5.2 & $\begin{array}{l}\text { Progressive Disciplinary Actions: Includes activities related to the } \\
\text { Progressive Discipline Action process. }\end{array}$ & & & & & & & 1 & 1 & 1 \\
\hline 5.3 & $\begin{array}{l}\text { Employee Communications: Includes activities related to } \\
\text { communicating to employees such as surveys, newsletters, workplace } \\
\text { meetings, all employee meetings, etc. }\end{array}$ & & & & & 1 & i & 1 & 1 & 1 \\
\hline 5.4 & $\begin{array}{l}\text { Collective Bargaining/Negotiating: Includes activities related to } \\
\text { negotiating the bargaining union contracts and/or manufacturing a } \\
\text { Westinghouse requested workforce. }\end{array}$ & & & & & $\begin{array}{l}1 \\
1 \\
1\end{array}$ & $\begin{array}{l}1 \\
1 \\
1\end{array}$ & $\begin{array}{l}1 \\
1 \\
1\end{array}$ & $\begin{array}{l}1 \\
1 \\
1\end{array}$ & $\begin{array}{l}1 \\
1 \\
1\end{array}$ \\
\hline 5.5 & $\begin{array}{l}\text { Administering Bargaining Union Contracts: Includes activities related to } \\
\text { administration of the bargaining union contracts such as grievances, etc. }\end{array}$ & & & & & $\begin{array}{l}1 \\
1 \\
1\end{array}$ & $\begin{array}{l}T \\
1 \\
1\end{array}$ & 1 & $\begin{array}{l}1 \\
1 \\
1\end{array}$ & 1 \\
\hline 5.6 & $\begin{array}{l}\text { Maintaining Westinghouse Representative Workforce: Includes } \\
\text { activities related to fair and equitable treatment of worker issues. }\end{array}$ & & & & & 1 & & 1 & 1 & 1 \\
\hline 5.7 & $\begin{array}{l}\text { EEO/Affirmative Action/ADA: Includes activities related to } \\
\text { EEO/Affirmative Action initiatives, ADA practices and reporting, } \\
\text { tracking/analyzing legislative issues. }\end{array}$ & & & & & $\begin{array}{l}1 \\
1 \\
1 \\
1\end{array}$ & $\begin{array}{l}T \\
1 \\
1 \\
1\end{array}$ & $\begin{array}{c}T \\
1 \\
1\end{array}$ & $\begin{array}{c}T \\
1 \\
1 \\
1\end{array}$ & $\begin{array}{l}1 \\
1 \\
1 \\
1\end{array}$ \\
\hline 5.8 & $\begin{array}{l}\text { Recognition and Service Awards: Includes activities relating to } \\
\text { recognizing employees such as family days, employee appreciation days, } \\
\text { service awards, etc. }\end{array}$ & & & & & $\begin{array}{l}1 \\
1 \\
1\end{array}$ & & $\begin{array}{l}1 \\
1 \\
1\end{array}$ & $\begin{array}{l}1 \\
1 \\
1\end{array}$ & $\begin{array}{l}1 \\
1 \\
1\end{array}$ \\
\hline 5.9 & $\begin{array}{l}\text { Other: Includes other activities relating to improving the quality of life of } \\
\text { employees such as wellness programs, the cafeteria and recreation } \\
\text { programs. }\end{array}$ & & & & & & & $\begin{array}{l}1 \\
1 \\
1\end{array}$ & $\begin{array}{l}1 \\
1 \\
1\end{array}$ & $\begin{array}{l}1 \\
1 \\
1\end{array}$ \\
\hline & TOTA & & 100 Points & & & & & & & \\
\hline
\end{tabular}


(10) WESTINGHOUSE HUMAN RESOURCES PROCESS SURVEY

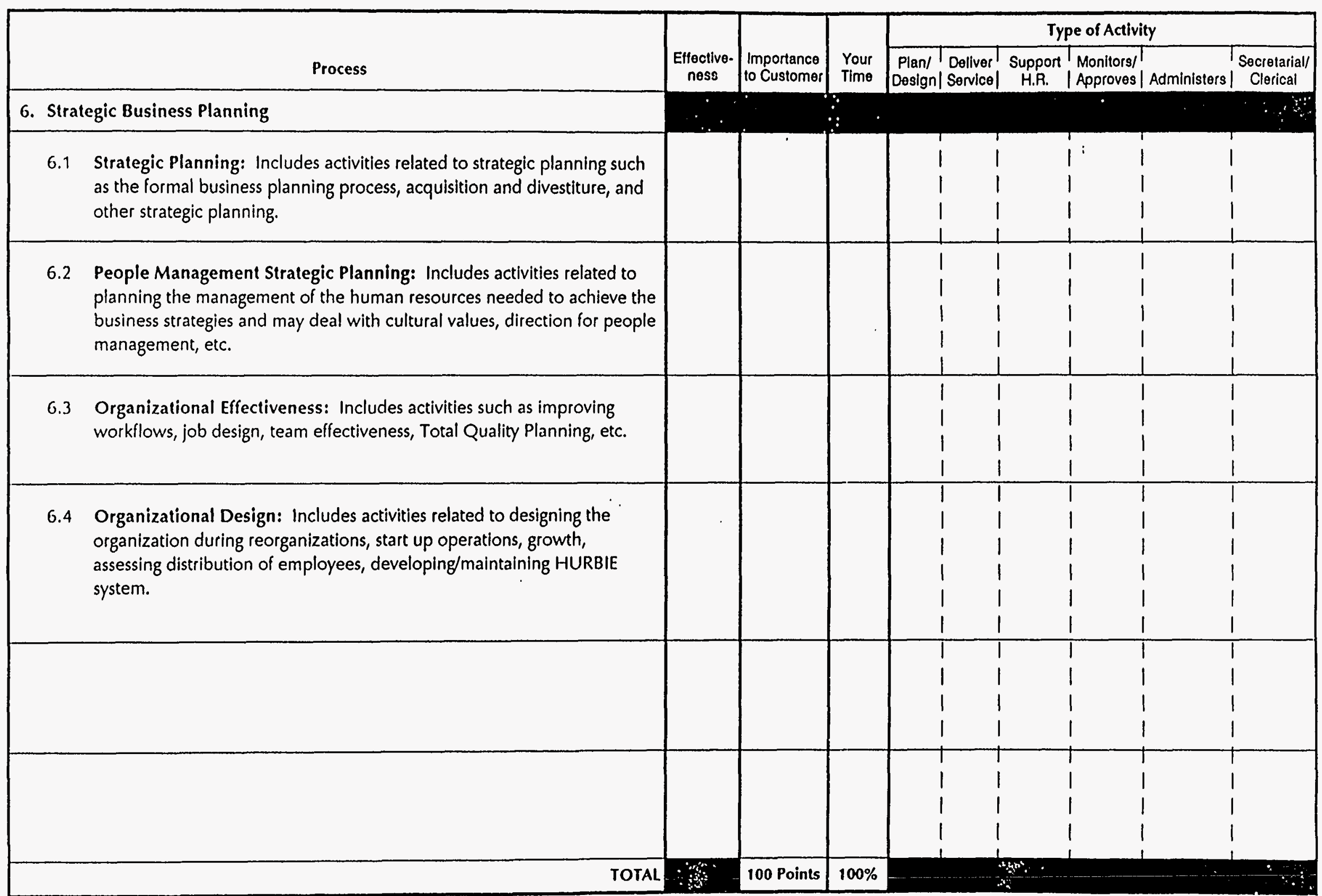

$-12$. 


\section{Section IV. Survey on Managing Your Own Staff}

This section should only be filled out by those respondents who spend time managing staff. If you entered 0\% for "Managing Your Own Staff" in Section II, do not fill out this section. 
(40) WESTINGHOUSE HUMAN RESOURCES PROCESS SURVEY

\begin{tabular}{|c|c|c|c|c|c|c|c|c|c|c|}
\hline \multirow{2}{*}{\multicolumn{2}{|c|}{ Process }} & \multirow[b]{2}{*}{$\begin{array}{c}\text { Efrective- } \\
\text { ness }\end{array}$} & \multirow{2}{*}{$\begin{array}{c}\text { Importance } \\
10 \\
\text { Customer }\end{array}$} & \multirow[b]{2}{*}{$\begin{array}{l}\text { Your } \\
\text { Time }\end{array}$} & \multicolumn{6}{|c|}{ Type of Activity } \\
\hline & & & & & $\begin{array}{l}\text { Plan/ } \\
\text { Deslgn }\end{array}$ & \begin{tabular}{|l|l|} 
Delliver \\
$\mid$ Service|
\end{tabular} & $\begin{array}{c}\text { Support } \\
\text { H.R. I }\end{array}$ & $\begin{array}{l}\text { Monitors/ } \\
\text { | Approves }\end{array}$ & | Administers | & $\begin{array}{l}\text { Secretarial/ } \\
\text { Clerical }\end{array}$ \\
\hline \multicolumn{11}{|c|}{ 7. Other } \\
\hline 7.1 & $\begin{array}{l}\text { Safety and Work Place Environmental Issues: Includes activities } \\
\text { related to green initiatives and regulatory affairs. }\end{array}$ & & & & & $\begin{array}{l}1 \\
1 \\
1 \\
1\end{array}$ & & $\begin{array}{l}1: \\
1 \\
1 \\
1\end{array}$ & $\begin{array}{l}1 \\
1 \\
1 \\
1\end{array}$ & $\begin{array}{l}1 \\
1 \\
1 \\
1\end{array}$ \\
\hline 7.2 & Medical: Includes attending injuries, periodic physical exams. & & & & & $\begin{array}{l}T \\
1 \\
1 \\
1 \\
1\end{array}$ & & $\begin{array}{l}1 \\
1 \\
1 \\
1 \\
1\end{array}$ & $\begin{array}{l}1 \\
1 \\
1 \\
1 \\
1\end{array}$ & $\begin{array}{l}1 \\
1 \\
1 \\
1 \\
1\end{array}$ \\
\hline 7.3 & Industrial Hygiene & & & & & $\begin{array}{l}1 \\
1 \\
1 \\
1 \\
1\end{array}$ & L & $\begin{array}{l}1 \\
1 \\
1 \\
1 \\
1 \\
\end{array}$ & $\begin{array}{l}1 \\
1 \\
1 \\
1\end{array}$ & $\begin{array}{l}1 \\
1 \\
1 \\
1 \\
1\end{array}$ \\
\hline 7.4 & Security, Facilities: Includes clearances and protection, information. & & & & & $\begin{array}{l}1 \\
1 \\
1 \\
1\end{array}$ & & $\begin{array}{l}1 \\
1 \\
1 \\
1\end{array}$ & $\begin{array}{l}1 \\
1 \\
1 \\
1\end{array}$ & $\begin{array}{l}1 \\
1 \\
1 \\
1\end{array}$ \\
\hline & Health Physics: Includes risks from hazardous/toxic wastes. & & & & & $\begin{array}{l}1 \\
1 \\
1 \\
1\end{array}$ & . & $\begin{array}{l}1 \\
1 \\
1 \\
1 \\
1\end{array}$ & $\begin{array}{l}1 \\
1 \\
1 \\
1 \\
1\end{array}$ & $\begin{array}{l}1 \\
1 \\
1 \\
1 \\
1\end{array}$ \\
\hline & & & & & & $\begin{array}{l}1 \\
1 \\
1 \\
1 \\
1\end{array}$ & & $\begin{array}{l}1 \\
1 \\
1 \\
1\end{array}$ & $\begin{array}{l}1 \\
1 \\
1 \\
1\end{array}$ & $\begin{array}{l}1 \\
1 \\
1 \\
1\end{array}$ \\
\hline & TOTAL & 8 & 100 Points & $100 \%$ & & & . & The & & \\
\hline
\end{tabular}

.13 - 
(VV WESTINGHOUSE HUMAN RESOURCES PROCESS SURVEY

1. Staff the Organization

(Manpower Planning, Headcount Reporting and Control, Preparing and Approving Requisitions, Internal Sourcing, External "On Demand"

Recruitment Programs, Temporary Staff Sourcing, Reassignments, Employee Separations, Relocations)

2. Train and Develop Employees

(Career Development, Performance Management, Succession Planning, Management Development, Program and Technical Skills Training, Interpersonal Skills Training, Orientation)

3. Compensating Employees

Job Evaluation and Classification, Salary Surveys/Competitive Analysis, Salary/Merit Plans, Alternative Compensation, Incentive

Compensation, Executive Compensation, Expatriate Compensation)

4. Benefiting Employees

(Healthcare Management, Welfare Management, Attendance Management, Savings and Investment Plans/With or Without $401(\mathrm{k})$, Pension

Management, Statutory Benefits)

5. Managing Employees/Labor Relations

(Non-Disciplinary Employee Counseling, Progressive Disciplinary Actions, Employee Communications, Collective Bargaining/Negotiating,

Administering Bargaining Union Contracts, EEO/Affirmative Action, Recognition and Service Awards)

\section{Strategic Business Planning}

(Strategic Planning, People Management Strategic Planning, Organizational Effectiveness, Organizational Design)

\section{Other}

(Safety, Medical, Industrial Hygiene, Security/Facilities, Health Physics, Workplace Environmental Issues)

TOTAL. 


\section{(W) WESTINGHOUSE HUMAN RESOURCES PROCESS SURVEY}

\section{B. Sub-Process Survey Sheets}

- As with Section II, the general processes have been further broken down into more detailed sub-processes. For each general process that you indicated time being spent, please complete the appropriate sub-process sheets. Leave all other sheets blank.

\section{- EFFECTIVENESS}

- Please rate the sub-processes in terms of how effectively each meets your needs (helps you in your business objectives).

- Different from Section II, you should rate all of the sub-processes, even ones you do not spend time on.

- Use the following scale:

$$
\begin{array}{ll}
1=\text { Don't use } & 4=\text { Meets most needs } \\
2=\text { Meets hardly any needs } & 5=\text { Meets all needs } \\
3=\text { Meets some needs } & 6=\text { Exceeds my needs }
\end{array}
$$

- IMPORTANCE

- For each sub-process, please spread 100 points to indicate your perception of how important each sub-process is to you in managing your employees. The more valuable the activity, the higher the point value you should assign to it.

- Different from Section II, you should rate all of the sub-processes, even ones you de not spend time on. Make sure the percentages add up to $100 \%$.

- TIME

- Please spread 100 percent to indicate the relative amount of time you spend on each sub-process for managing your employees. Make sure the percentages add up to $100 \%$. 


\begin{tabular}{|c|c|c|c|c|}
\hline & Process & $\begin{array}{c}\text { Efroctive- } \\
\text { ness }\end{array}$ & $\begin{array}{c}\text { Importance } \\
\text { to Your } \\
\text { Job }\end{array}$ & $\begin{array}{l}\text { Your } \\
\text { Time }\end{array}$ \\
\hline \multicolumn{2}{|c|}{ 1. Staff the Organization } & \multicolumn{3}{|c|}{$\therefore$} \\
\hline 1.1 & $\begin{array}{l}\text { Manpower Planning: Includes capacity requirement planning, and other } \\
\text { activities that are included in planning where people are going, what } \\
\text { people are needed, and what adjustments are needed to current } \\
\text { manpower, including expatriate counseling, etc. }\end{array}$ & & & ; \\
\hline 1.2 & $\begin{array}{l}\text { Headcount Reporting and Control: Includes all activities performed in } \\
\text { the headcount reporting process, maintaining organization charts, } \\
\text { telephone directories, personnel lists, PRISM forms. }\end{array}$ & & & \\
\hline 1.3 & $\begin{array}{l}\text { Preparing and Approving Requisitions: Includes all activities performed } \\
\text { in preparing and obtaining approval for requisitions for full time } \\
\text { employees and temporary employees. }\end{array}$ & & & \\
\hline 1.4 & $\begin{array}{l}\text { Internal Sourcing: Includes all activities performed in obtaining people } \\
\text { through internal sources such as posting, interviewing, transferring, } \\
\text { promotions, career opportunity bulletin, etc. }\end{array}$ & & & \\
\hline 1.5 & $\begin{array}{l}\text { External "On-Demand" Recruitment: Includes activities performed in } \\
\text { obtaining people with special skills, i.e., the special purpose recruitment, } \\
\text { such as sourcing, tracking applicants, advertising, Interviewing, selecting, } \\
\text { hiring, etc. Does not include college recruitment programs and } \\
\text { contractors/temps. }\end{array}$ & & & \\
\hline 1.6 & $\begin{array}{l}\text { Recruitment Programs: Includes activities related to obtaining people } \\
\text { through special recruitment programs (i.e., college, summer intern, } \\
\text { co-ops) such as forecasting, scheduling, interviewing, selecting, hiring, } \\
\text { Engineering Manufacturing Professional Development Program, Human } \\
\text { Resources Development Program. }\end{array}$ & & & \\
\hline 1.7 & $\begin{array}{l}\text { Temporary Staff Sourcing: Includes all activities related to obtaining } \\
\text { temporary staff such as temps, contractors, part-time employees. }\end{array}$ & & & \\
\hline 1.8 & $\begin{array}{l}\text { Reassignments: Includes all activities related to reassigning employees or } \\
\text { placing them on temporary assignment within their own location or } \\
\text { division due to an oversupply of resources, reorganizations, temporary } \\
\text { assignments, restructuring, factory personnel shuffling, etc. }\end{array}$ & & & \\
\hline 1.9 & $\begin{array}{l}\text { Employment Separations: Includes activities related to separating } \\
\text { employees from Westinghouse or from their division. The activities } \\
\text { include severance continuations, exit interviews, layoffs/shutdowns, } \\
\text { deaths, outplacement, etc. }\end{array}$ & & & \\
\hline 1.10 & $\begin{array}{l}\text { Relocations: Includes activities related to physically moving employees, } \\
\text { their families and properties. }\end{array}$ & & & \\
\hline & TOTAL & & 100 Points & $100 \%$ \\
\hline
\end{tabular}


(12) WESTINGHOUSE HUMAN RESOURCES PROCESS SURVEY

\begin{tabular}{|c|c|c|c|c|}
\hline \multicolumn{2}{|r|}{ Process } & $\begin{array}{c}\text { Effective } \\
\text { ness }\end{array}$ & $\begin{array}{l}\text { Importance } \\
\text { to Your } \\
\text { Job }\end{array}$ & $\begin{array}{l}\text { Your } \\
\text { Time }\end{array}$ \\
\hline \multicolumn{5}{|c|}{ 2. Train and Develop Employees } \\
\hline 2.1 & $\begin{array}{l}\text { Career Development: Includes activities such as coaching, counseling, } \\
\text { advising, mentoring, etc. }\end{array}$ & & & : \\
\hline 2.2 & $\begin{array}{l}\text { Performance Management: Includes activities relating to assessing } \\
\text { personnel, setting objectives, appraising performance, etc. }\end{array}$ & & & \\
\hline 2.3 & $\begin{array}{l}\text { Succession Planning: Includes activities related to identifying and } \\
\text { developing high potential candidates, including cross functional } \\
\text { assignments and construction/maintenance of data base/data book. }\end{array}$ & & & \\
\hline 2.4 & $\begin{array}{l}\text { Management Development: Includes activities related to training, } \\
\text { education and awareness of supervisory and management personnel - } \\
\text { including the assessment center activity. }\end{array}$ & & & \\
\hline 2.5 & $\begin{array}{l}\text { Program and Technical Skills Training: Includes activities related to the } \\
\text { training of technical skills to participants and employees. }\end{array}$ & & & \\
\hline 2.6 & $\begin{array}{l}\text { Interpersonal Skills Training: Includes activities related to developing } \\
\text { interpersonal skills for employees such as team building, human relations, } \\
\text { effective communications, personal effectiveness, etc. }\end{array}$ & & & \\
\hline 2.7 & $\begin{array}{l}\text { Orientation: Includes activities related to training employees to be able } \\
\text { to perform a new assignment, such as information on benefits, work } \\
\text { rules, product knowledge, contribution to business purpose, ethics, code } \\
\text { of conduct, safety, quality, etc. }\end{array}$ & & & \\
\hline & TOTAL. & & 100 Points & $100 \%$ \\
\hline
\end{tabular}


(2V) WESTINGHOUSE HUMAN RESOURCES PROCESS SURVEY

\begin{tabular}{|c|c|c|c|c|}
\hline & Process & $\begin{array}{c}\text { Effective- } \\
\text { noss }\end{array}$ & $\begin{array}{c}\text { Importance } \\
\text { to Your } \\
\text { Job }\end{array}$ & $\begin{array}{l}\text { Your } \\
\text { Time }\end{array}$ \\
\hline \multicolumn{5}{|c|}{ 3. Compensating Employees } \\
\hline 3.1 & $\begin{array}{l}\text { Job Evaluation and Classification: Includes activities related to } \\
\text { evaluating and classifying jobs. }\end{array}$ & & & \\
\hline 3.2 & $\begin{array}{l}\text { Salary Surveys/Competitive Analysis: Includes activities related to salary } \\
\text { surveys and competitive analysis. }\end{array}$ & & & \\
\hline 3.3 & $\begin{array}{l}\text { Salary/Merit Plans: Includes activities such as budgeting, merit planning, } \\
\text { presentations and approval analysis. }\end{array}$ & & & \\
\hline 3.4 & $\begin{array}{l}\text { Alternative Compensation: Includes activities related to broad based, } \\
\text { short-term incentive plans such as profit sharing, gain sharing, project } \\
\text { related and/or team based. }\end{array}$ & & & \\
\hline 3.5 & $\begin{array}{l}\text { Incentive Compensation: Includes activities related to narrowly focused, } \\
\text { short-term incentive plans such as sales, special performance awards, } \\
\text { other special awards, stock-based awards, etc. }\end{array}$ & & & \\
\hline 3.6 & $\begin{array}{l}\text { Executive Compensation: Includes activities related to long-term } \\
\text { incentives for executives and executive benefits programs (such as } \\
\text { executive pensions). }\end{array}$ & & & \\
\hline \multirow[t]{2}{*}{3.7} & $\begin{array}{l}\text { Expatriate Compensation: Includes activities relating to compensating } \\
\text { expatriates. }\end{array}$ & & & \\
\hline & TOTAL & & 100 Points & $100 \%$ \\
\hline
\end{tabular}

$-18$. 
(2) WESTINGHOUSE HUMAN RESOURCES PROCESS SURVEY

\begin{tabular}{|c|c|c|c|c|}
\hline & Process & $\begin{array}{c}\text { EHective } \\
\text { ness }\end{array}$ & $\begin{array}{c}\text { Importance } \\
\text { to Your } \\
\text { Job }\end{array}$ & $\begin{array}{l}\text { Your } \\
\text { Time }\end{array}$ \\
\hline \multicolumn{5}{|c|}{ 4. Benefiting Employees } \\
\hline 4.1 & $\begin{array}{l}\text { Healthcare Management: Includes activities related to developing or } \\
\text { managing the healthcare of employees such as medical plans, dental plans. }\end{array}$ & & & \\
\hline 4.2 & $\begin{array}{l}\text { Welfare Management: Includes activities related to managing the welfare } \\
\text { of employees such as Insurance, Short Term Disability (STD), Long Term } \\
\text { Disability (LTD), etc. }\end{array}$ & & & \\
\hline 4.3 & $\begin{array}{l}\text { Attendance Management: Includes activities related to employee time-off } \\
\text { with and without pay, such as jury duty, compensatory time, illness, } \\
\text { vacation, holidays, disabilities and activities related to managing } \\
\text { employees back into the workforce. }\end{array}$ & & & \\
\hline 4.4 & $\begin{array}{l}\text { Savings and Investment Plans/With or Without } 401(k) \text { : Westinghouse } \\
\text { Stock Plan, Credit Unions, bonds, etc. }\end{array}$ & & & \\
\hline 4.5 & $\begin{array}{l}\text { Pension Management: Includes activities related to supporting the } \\
\text { retirement process and preparation for retirement, l.e., financial planning, } \\
\text { advice, counsel, elections, plan development. }\end{array}$ & & & \\
\hline 4.6 & $\begin{array}{l}\text { Statutory Benefits: Includes activities related to workers' compensation, } \\
\text { unemployment compensation. }\end{array}$ & & & \\
\hline & TOTAL & & 100 Points & $100 \%$ \\
\hline
\end{tabular}

$\cdot 19$ - 
(N2 WESTINGHOUSE HUMAN RESOURCES PROCESS SURVEY

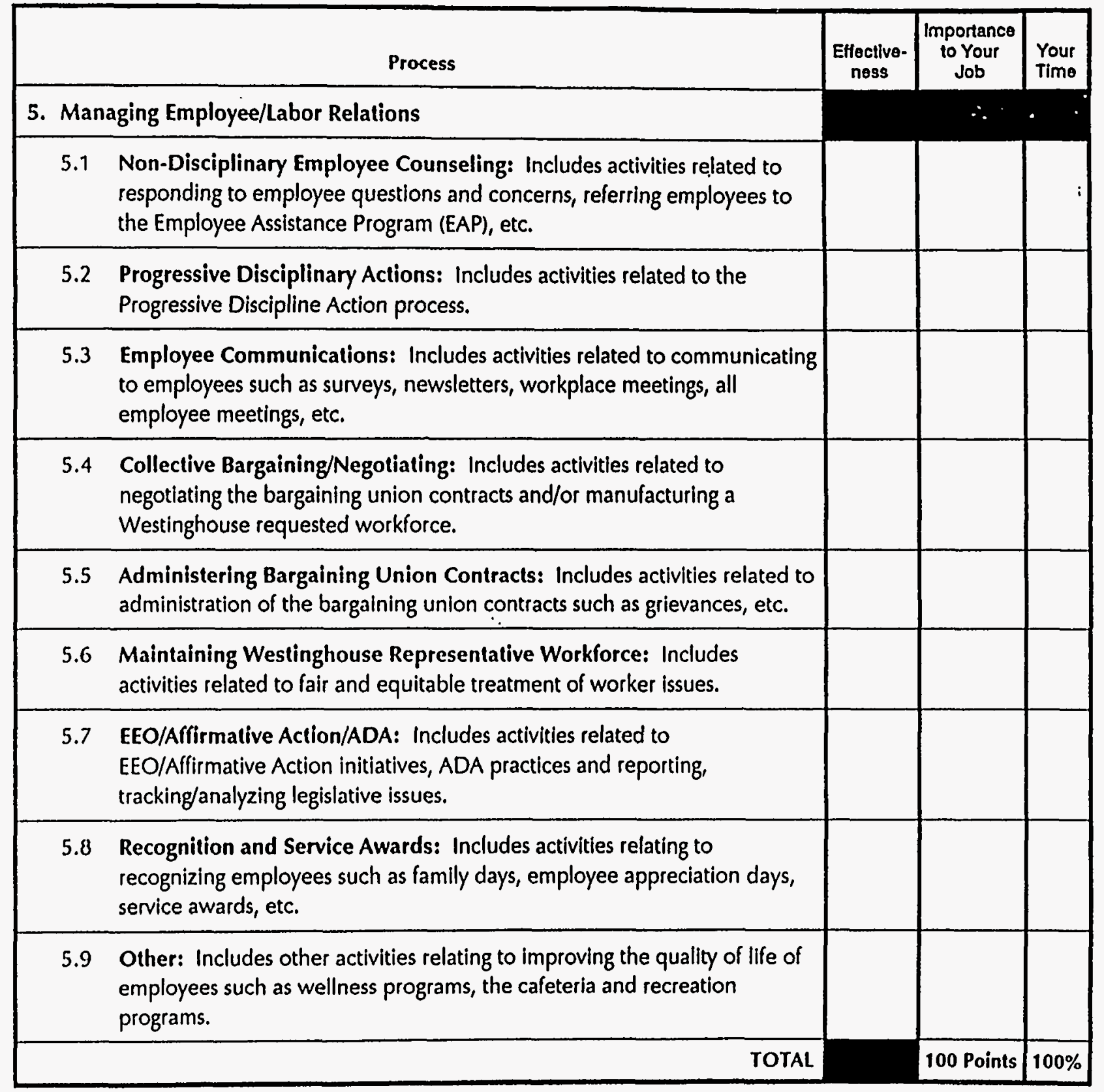


(VV) WESTINGHOUSE HUMAN RESOURCES PROCESS SURVEY

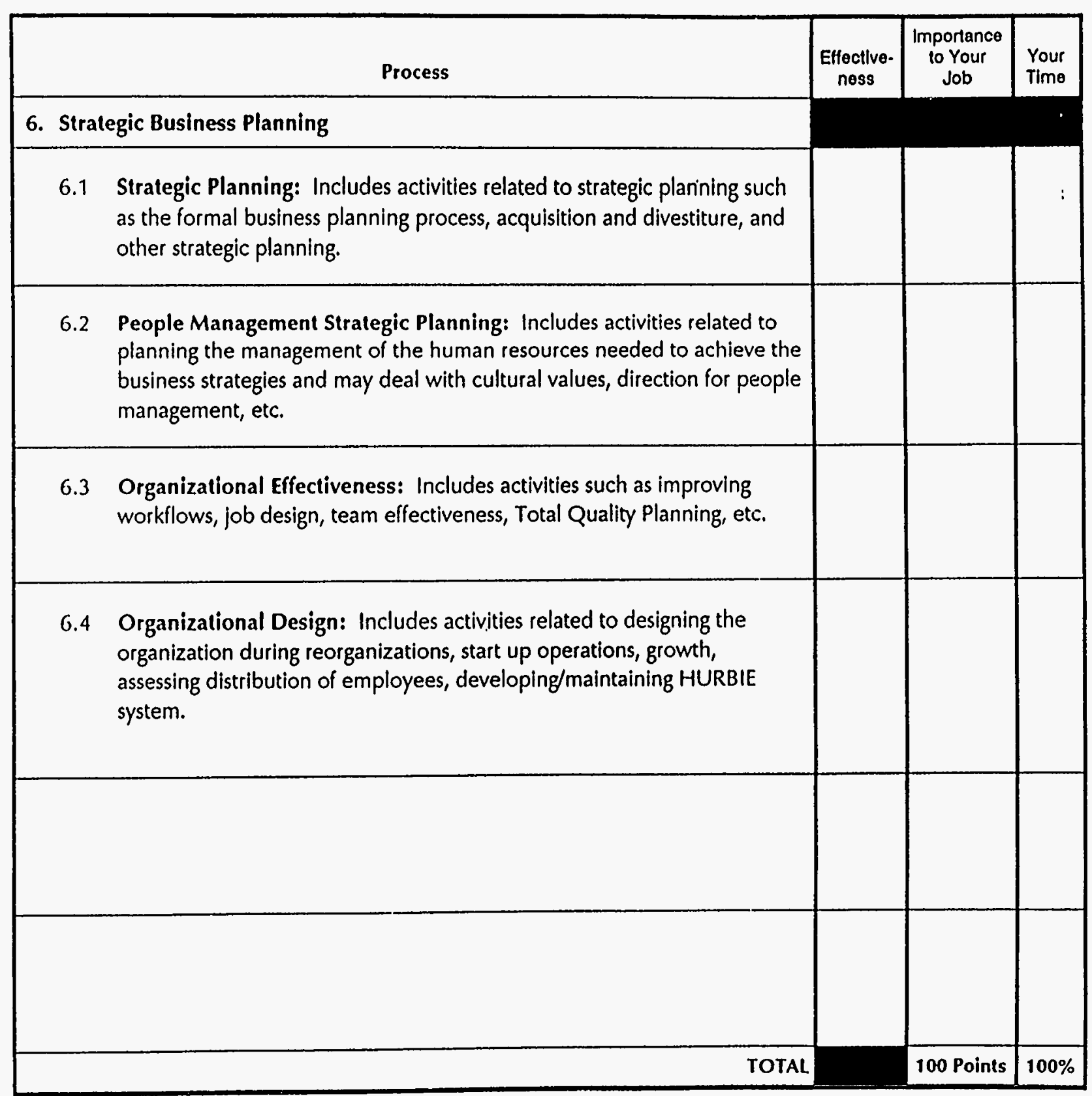


(NV) WESTINGHOUSE HUMAN RESOURCES PROCESS SURVEY

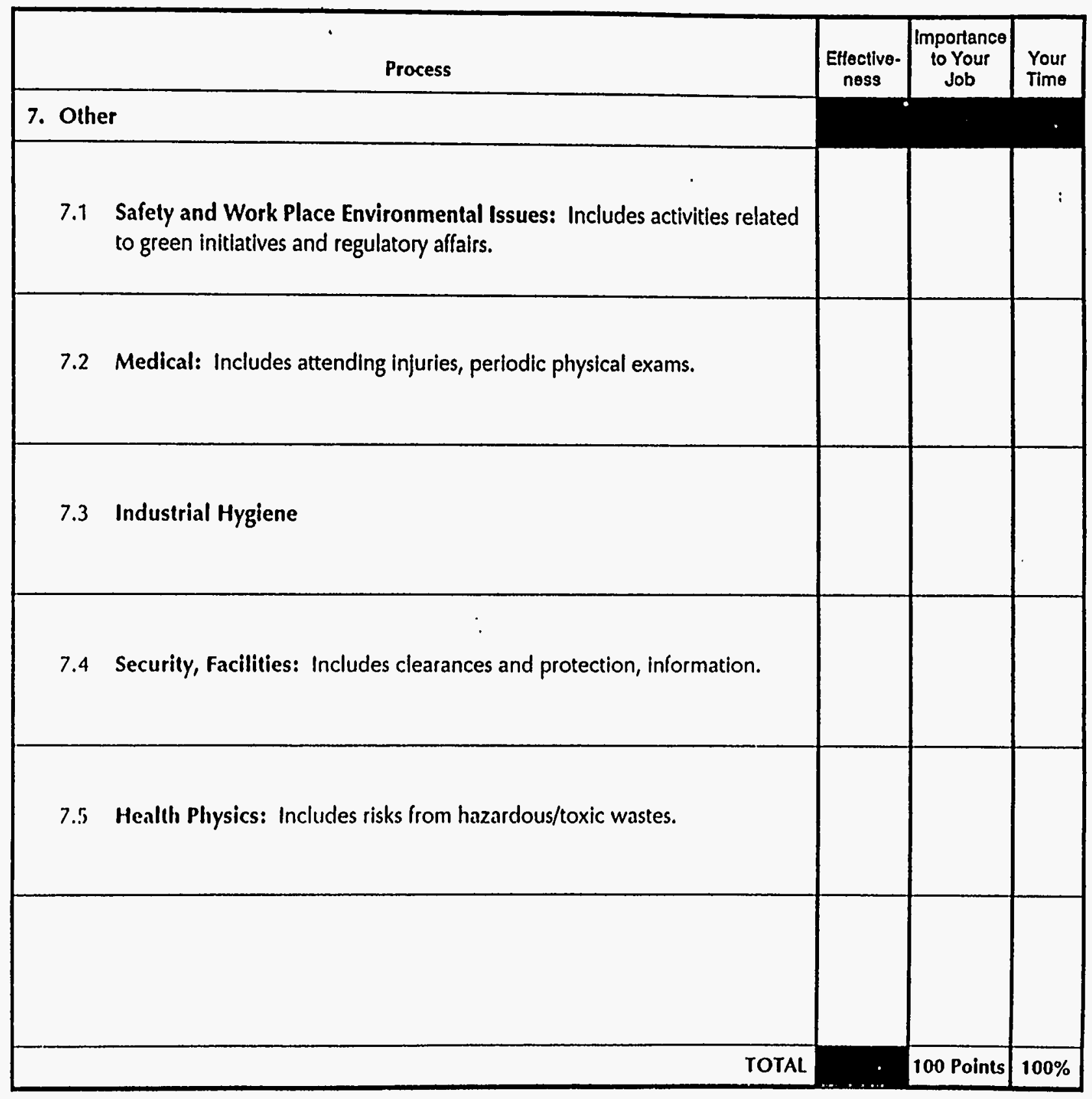

.22. 
PREDECISIONAL DRAFT, REV. 1

THIS PAGE

LEFT BLANK

INTENTIONALLY

PREDECISIONAL DRAFT, REV. 1 
D.2

XEROX Core - Optional Analysis

D - 5 


\section{THIS PAGE \\ LEFT BLANK \\ INTENTIONALLY}

D- 6 


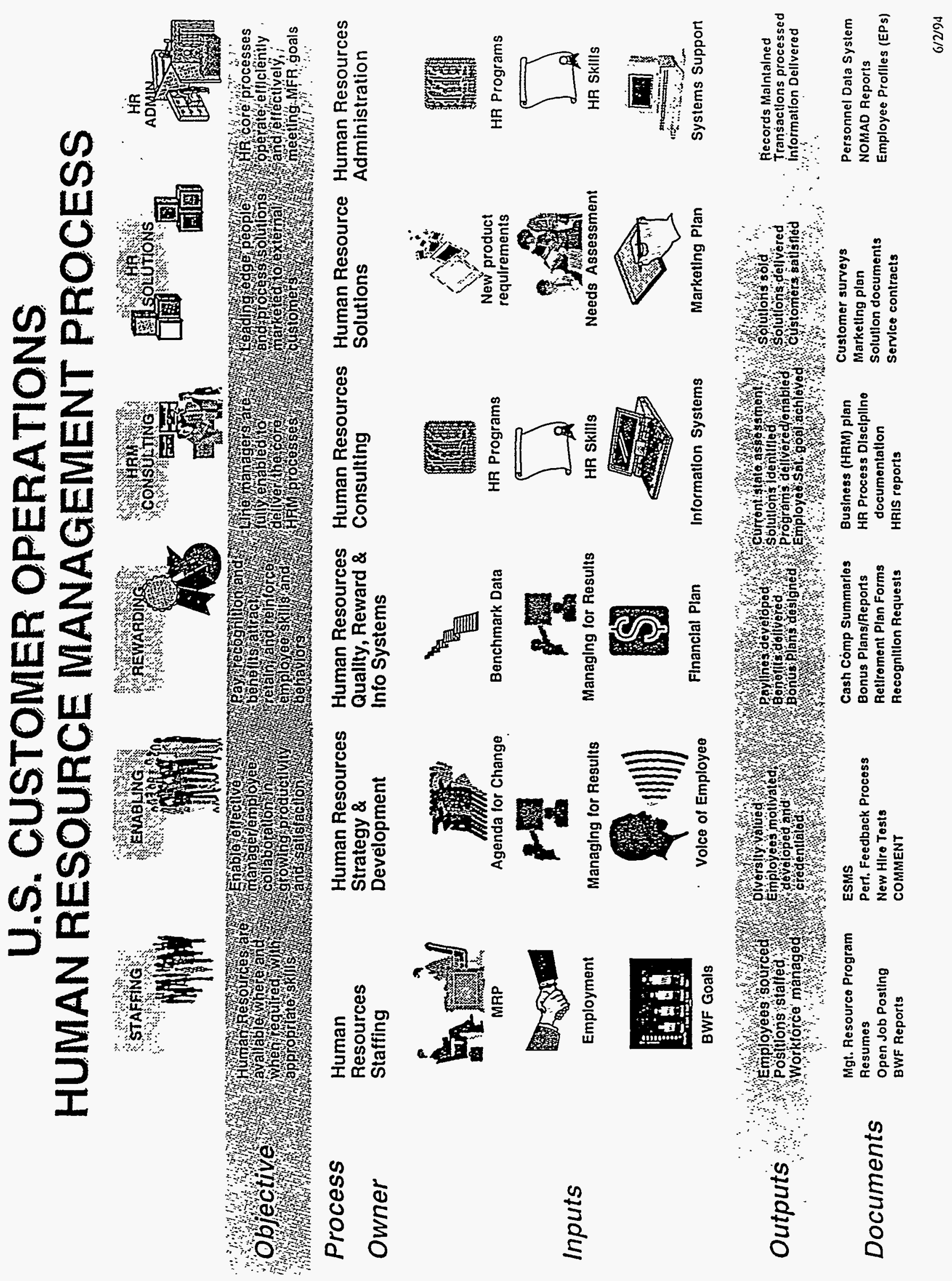




\section{U.S. CUSTOMER OPERATIONS \\ HUMAN RESOURCE MANAGEMENT PROCESS}

CORE

PROGESSES

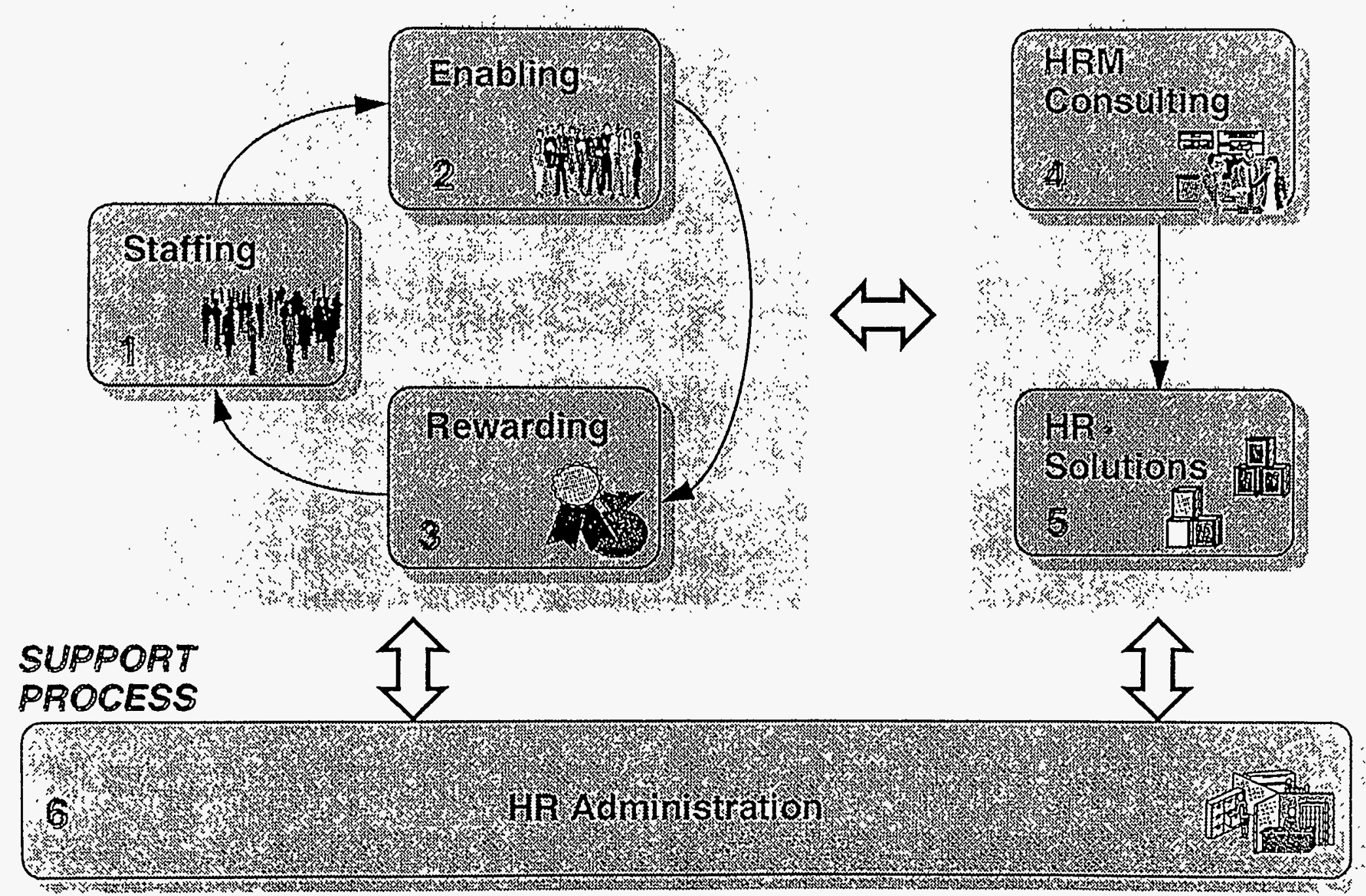

DELIHERY PROCESSES 

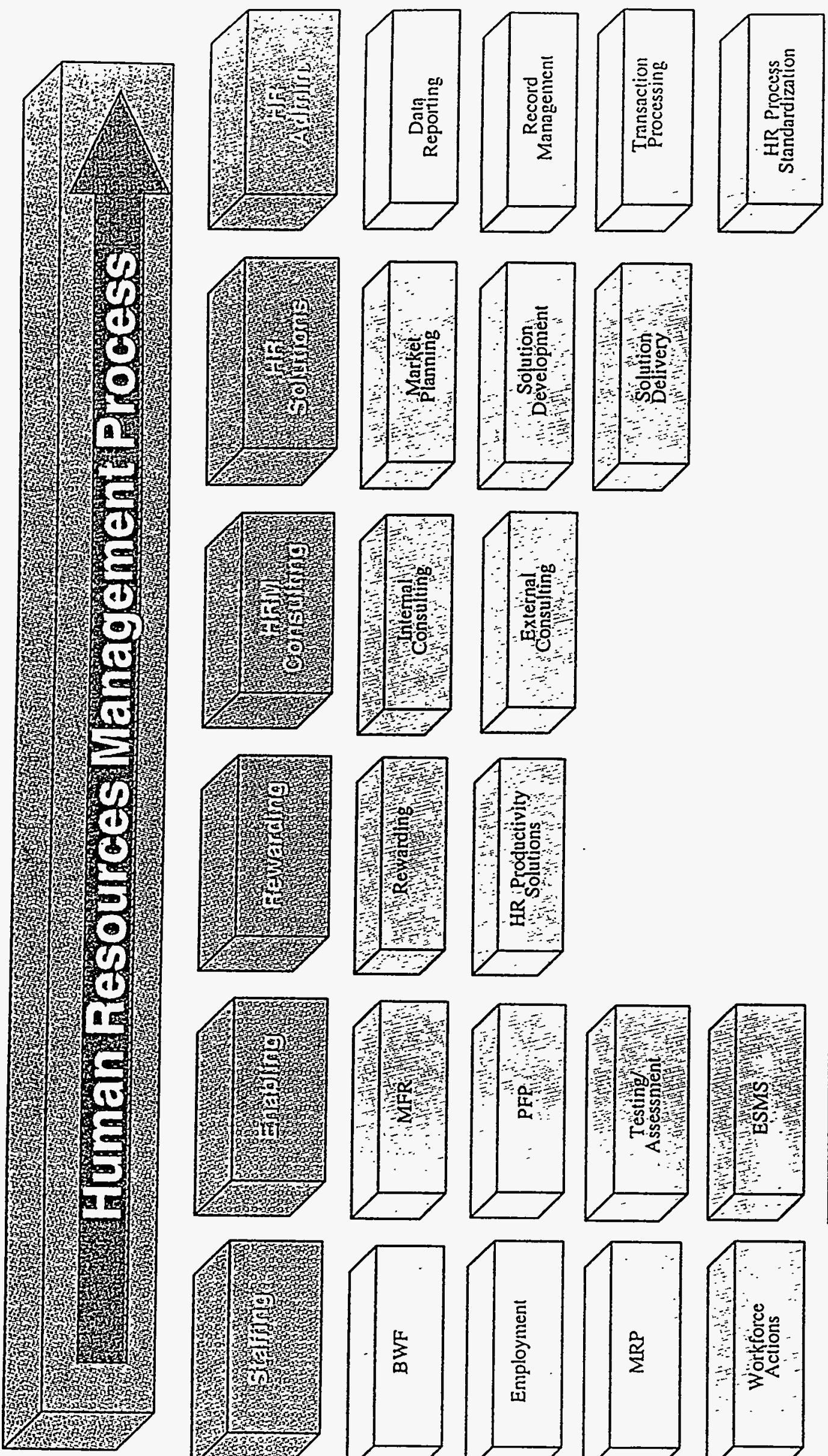

胥
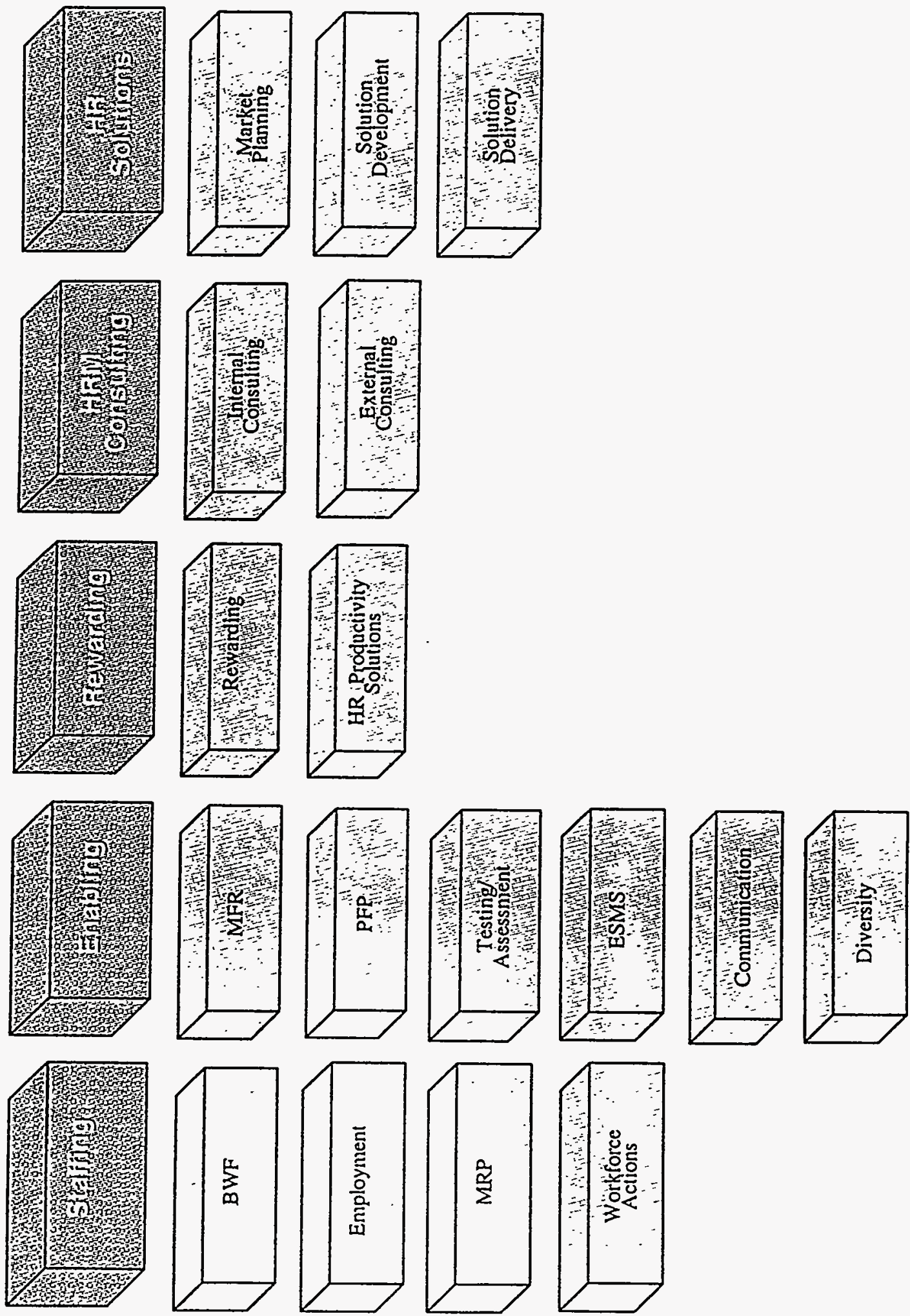

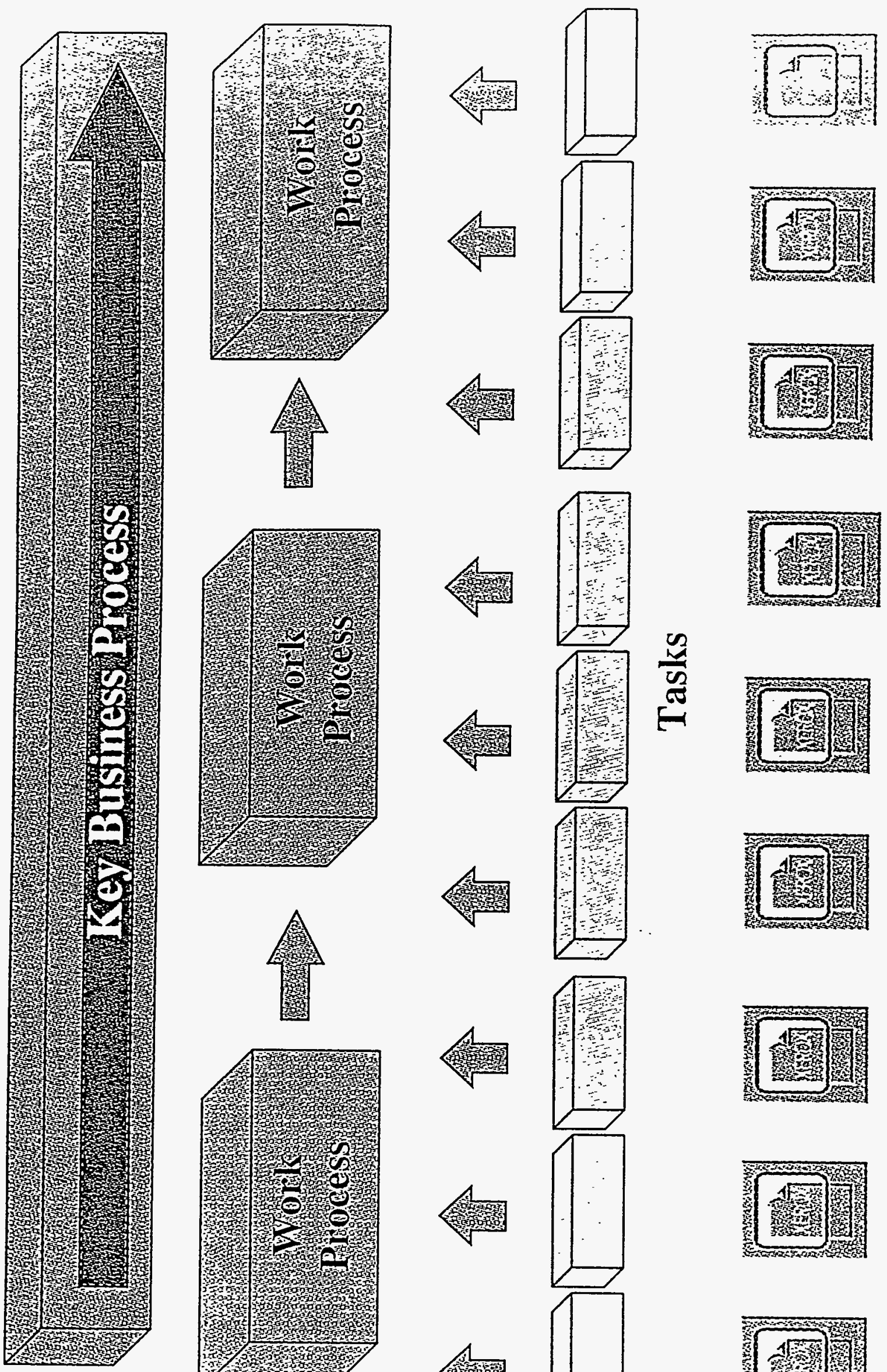

$\frac{3}{\frac{2}{4}}$
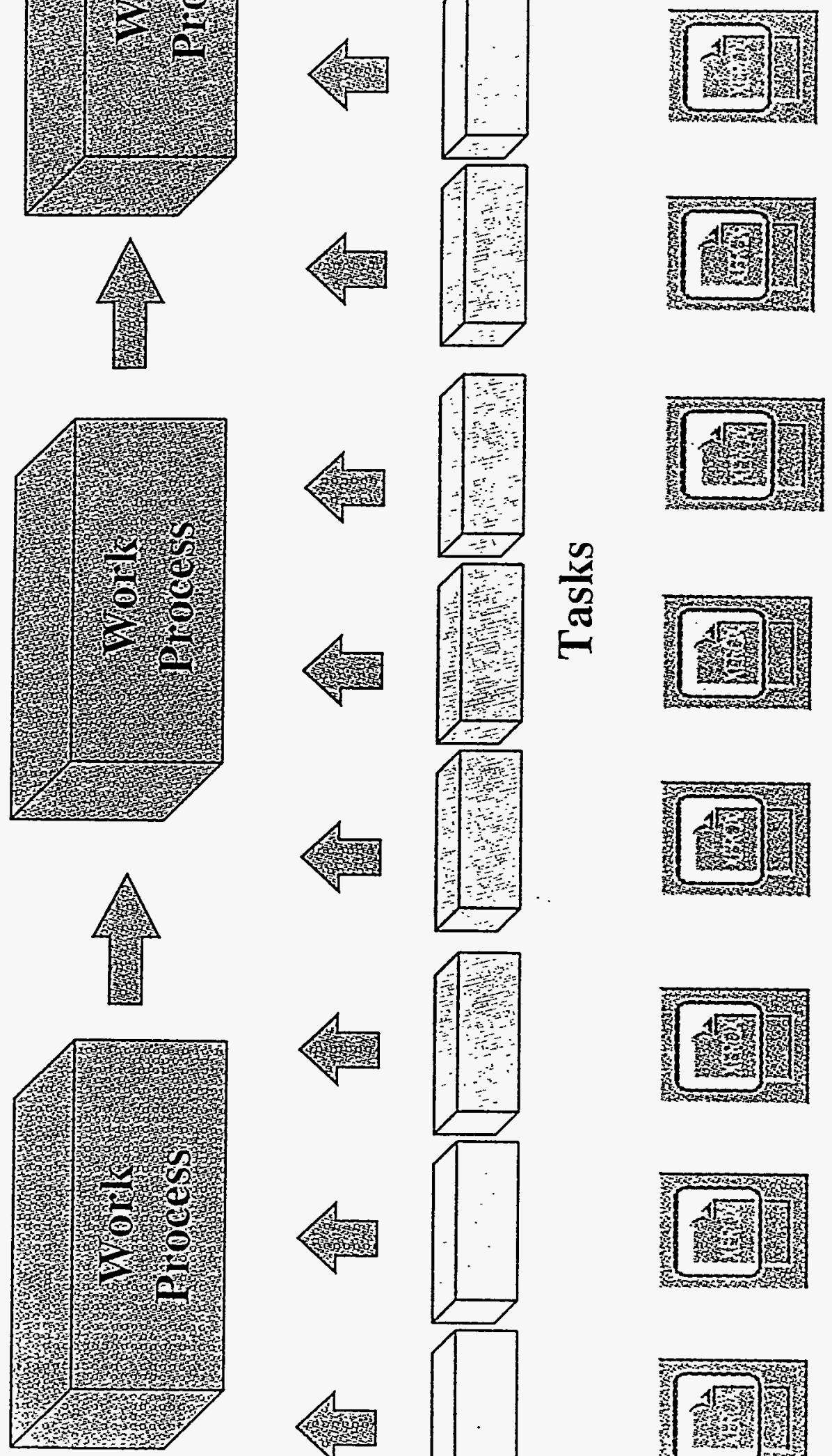

$\frac{n}{n}$
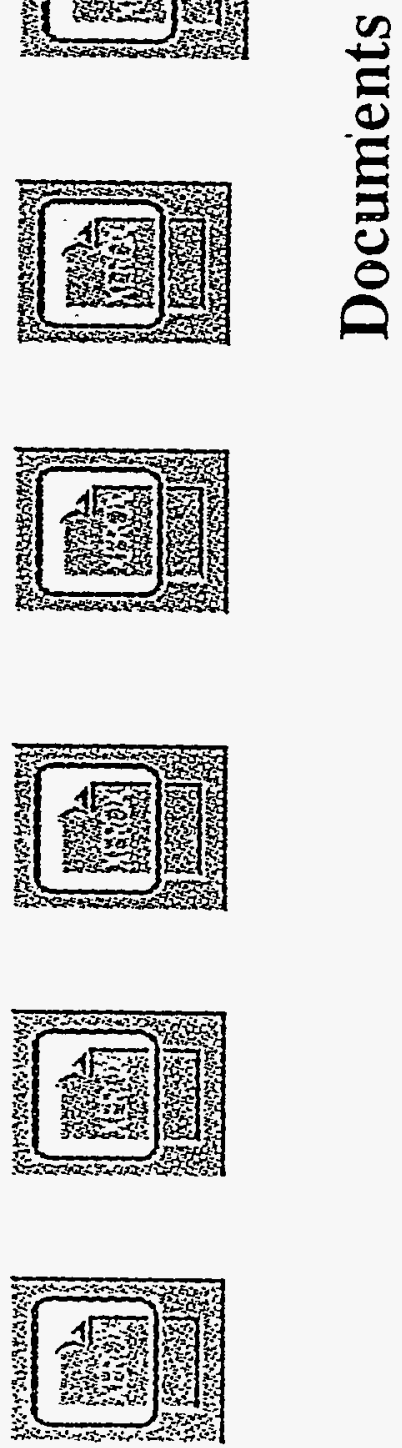
D.3 IBM Core - Optional Analysis (Selected Examples)

\section{BASE}

Employment

Resources

Medical Benefits

Compensation

Training \&

Development

Resumix

EAP
Policies \& Practices

Recruiter Training

Plan \& Strategy

Job Posting

Redeployment

Medical/Dental Coverage

Life Insurance (Group)

Salary Program

Salary Surveys

Job Evaluation

Management Development

Employee Orientation

Performance Management

Qccupational Health
Industrial Hygiene Safety

Emergency Care

\section{OPTIONAL}

Special Advertising Agency Fees (Exec. Recruiters) Special Testing

Outplacement

Assessment Programs

Term Life Insurance Additional LTD Coverage

Additional Catastrophic Coverage

Alternative Incentive Program Special Salary Surveys Unique Award Plans Special Recognition Events

Unique Skills Building Courses Team Building Courses Interpersonal Skills Development Special Seminar Programs

Employee Primary Care Health Wellness Courses 


\section{THIS PAGE \\ LEFT BLANK \\ INTENTIONALLY}

D- 8 


\section{APPENDIX E}

\section{INDEPENDENT TECHNICAL REVIEW TEAM MEMBERSHIP AND CREDENTIALS}

E.1

Independent Technical Review Team Members

Doug Weaver, Co-leader Red Team

Dr. Philip Thullen, Co-leader Red Team

Bechdel, Wendy

Boyle, Jerry

Brown, Joe

Brown, Wavery

Crowe, Laura

Doggette, John

Knightstep, Charles

Marts, Terri

Murphy, Michael

Paradiso, Jane

Peebles, Harry

Perry, Richard

Remington, Carol

Richmond, Chester

Sexton, Beth

Trevisani, Jeri 
Name: $\quad$ Wendy F. Bechdel

Education: $\quad$ BBA, Accounting, University of New Mexico, 1979

MBA, Management Information Systems, UNM, 1984

Affiliation: Sandia National Laboratories (SNL)

Experience: Mrs. Bechdel has 16 years of business/financial experience in the federal and private sector. This experience includes administrative management, strategic and operational planning, financial analysis, policy development, and systems analysis, design and implementation. Her career at Sandia has included administrative or technical assignments in General Accounting, Data Planning and Operations, Financial Policies and Procedures, Budgeting, Facilities Information Systems, Engineered Materials \& Processes, and Component Development and Engineering Support. In addition, she has a background in accounting and finance from her experience in private industry.

Currently, Mrs. Bechdel is the VP Administrative Manager for the Component Development and Engineering Support Division. In this capacity, she is responsible for the administrative operations of the division. Administrative operations include planning, review, analysis, and implementation in the areas of budgeting \& costing; staffing (including new hires, internal transfers, reclassifications, promotions, redeployment, EEO/AA goals); performance and compensation; diversity; educational outreach; training; and strategic and operational planning. She is a member of the corporate Resource Allocation Team and a Diversity Champion. 
Name:

Education:

Affiliation: Boyle \& Associates

Experience: Dr. Boyle has over twenty-five years of diverse experience in human resource development and management. His areas of specialization are: leadership development, HRD strategies, empowerment, employee involvement and team building.

At Florida Power Corporation, Dr. Boyle was responsible for succession planning, leadership and management development, employee surveys, assessment and testing, career development programs, customer service and craft training for over 6,000 executive, management, exempt, nonexempt and represented employees. He had a staff of 51 and an annual budget of over $\$ 3 \mathrm{M}$.

While with Honeywell Military Avionics Division, he established a "green-field" full service HR department. This department supported a workforce of over 1,300 whose business was changing from cost-plus to fixed-price. He was the HR leader for two layoffs of over 800 employees from his own and two other division.

At Martin Marietta Aerospace in Orlando, Florida, he was manager of three different departments: Human Resource Development, Employment and Personnel Management. He initiated and managed a highly effective Quality Circle program and a comprehensive management training and development program. In addition, he created a skills training and competency certification system for production technicians and assemblers.

Previously, he had management and organization development experience with two federal agencies, the Internal Revenue Service, Atlanta, Georgia, the Postal Service, Training and Development Institute, Bethesda, Maryland, and the Monroe County School System, Key West, Florida. 
Name: $\quad$ Ioseph E. Brown

Education: $\quad$ B. S. Business, Rider University, 1966

Affiliation: IBM Corporation (WFS Workforce Solutions)

Experience: Mr. Brown has over twenty-eight years of experience in the manufacturing and data processing industry, with extensive knowledge of the different human resource disciplines gained from managing them in a broad range of environments. He provides human resource consulting services to IBM divisions in assessing the human resource implications of potential acquisitions, mergers and divestitures, and general human resource consulting to other clients.

Mr. Brown recently led the human resource negotiations that assisted in the formation of several joint venture companies and creation of a new company. - He also developed human resource policies and programs differing from their parent organizations that were reflective of their start-up nature and culture desired.

During his twenty-eight years with IBM, Mr. Brown has held management positions in all the functional areas of human resources, in a number of IBM divisions. These assignments have spanned the gambit of managing human resources at the site (development), field (marketing), independent business units and division levels. Mr. Brown managed IBM's resource programs for the United States when IBM's employee population was over 250,000 . He managed the human resource, communications, administration, and facilities at IBM's Houston site that developed software and the on-board computers for the Space Shuttle Program, prior to and during the launch of the first space shuttle. He has managed a number of consolidations and restructuring programs for different units within IBM.

Prior to joining IBM, Mr. Brown worked for Rider University managing their alumni programs and publishing the alumni magazine. 
Name: $\quad$ Wavery W. Brown

Education: $\quad$ MBA, Baldwin - Wallace College, 1985

Affiliation: Battelle Pacific Northwest Laboratory (PNL)

Experience: Ms. Brown has seventeen years experience in Human

Resource management and operations in manufacturing, steel and research environments. She currently provides management support and leadership to eleven Human Resource Generalists. Her responsibilities are to assure the development, implementation, communication and monitoring of human resource programs and strategic initiatives; integration of human resource programs and initiatives to Laboratory business plans and strategy; interpret and ensure compliance with federal, state and local legislation; integration of the Department of Energy and Battelle Memorial Institute guidelines and requirements and the development of Laboratory-wide policies, procedures and programs using the total quality-concept.

Wavery designed the first human resource strategic planning process for PNL. She recently led the process in designing the PNL Staff Handbook which is scheduled for distribution in October. She was also responsible for the selection and integration of People Soft Human Resource Information System; and updating the Laboratory HR policies and procedures to provide clarity of management ownership and guidance.

Wavery started her HR career as a compensation specialist where she designed a job description library and assisted in the development and implementation of an in-house HR on-line system. She also held the position of an Employee Relations Specialist where she did recruiting, and designed a downsizing program which included an outplacement process. From 1986 to 1990 she was the Manager - Human Resources for a start-up steel company. There, she was responsible for developing an employee participative, nonunion environment. Her responsibilities included hiring; developing policies and procedures; benefits selection; Affirmative Action Planning; training and development; designing and implementing quality of work life programs; profit sharing program; performance review and salary administration programs. 
Name:

Laura S. Crowe

Education: $\quad$ BSN, University of New Mexico, 1981

Affiliation: Honeywell, Inc.

Experience: Ms. Crowe is currently the Team Leader for Benefits, Staffing and Health Services at Honeywell, Inc., Defense Avionics Systems Division. She has 13 years of experience in nursing, seven of those years in occupational health nursing. She holds certifications in occupational health nursing and medical case management.

Ms. Crowe is currently responsible for the design, planning and implementation of all health care benefits for the Albuquerque region, and the direction and delivery of staffing and health services programs. The Employee Assistance/Mental Health plan designed by Ms. Crowe has become the model for the company. She was invited to present the design at a national conference on behavioral health. Many programs offered through health services, especially large case management, have become the standard for the company.

Ms. Crowe's past experience includes psychiatric nursing in acute care facilities. Her responsibilities included responsibility for up to 44 patients and 15 staff members. She also set up the occupational health services for Philips Semiconductors in Albuquerque. 
Name: $\quad$ John R. Doggette

Education: M.A. and B.S. University of Cincinnati

M.S. Urban Affairs, University of Wisconsin

Ed.D, Higher Education, Indiana University, 1974

Affiliation: Oak Ridge Institute for Science and Education (ORISE)

Experience: Dr. Doggette is Associate Director of the Training and Management Systems Division, ORISE an organization who provides training and performance support to the Department of Energy and its contractors. The Division has current contracts with fourteen DOE Headquarters and Operations Offices, plus 35 other clients including $M \& O$ contractors, Federal and State agencies and private industry. During his twenty-two years at ORISE, Dr. Doggette has been managed or supported over 100 worker assessment, technical training delivery and evaluation projects. TMSD manages the DOE network of training professionals, TRADE the Training Resources and Data Exchange that Dr. Doggette cofounded in 1979.

Dr. Doggette has been invited to participate on assessments and assist visits at many contractor sites including Rocky Flats, Y-12, Sandia, ITRI, CTA Mound, Fernald, Idaho Falls, Rocky Flats, Livermore and Stanford. He participated as a training team leader on the Los Alamos National Laboratory Tiger Team and in the assessment of overall Tiger Team training findings.

He has numerous professional presentations reports and articles in the field. Prior to joining ORISE he was a faculty member at Clemson University and Indiana University. 
Name: $\quad$ Charles R. Knightstep

Education: $\quad$ BA, Psychology, San Jose State University

Post Graduate Work, Human Resources and Organization

Development, University of San Francisco

Affiliation: Knightstep Consulting

Experience: Mr. Knightstep has over twenty years of Human Resources Management experience. He has had the opportunity to develop strategies, policies, and programs in all phases of the discipline. His experience has included both union and nonunion environments. Mr. Knightstep has particular expertise in policy development, employee relations, compensation planning, senior management counseling, and in the legal aspects of Human Resources. Mr. Knightstep is also academically and professionally prepared in the areas of Organization Development and Total Quality Management.

Prior to consulting, Mr. Knightstep held management positions in Human Resources with Thrifty Drug, The Kellogg Company, Boise Cascade, and Syntex. At Thrifty Drug and The Kellogg Company, his primary responsibilities were in the labor relations arena, including grievance resolution and contract negotiations. At Boise Cascade he was responsible for all labor relations and human resources activities. His thirteen years at Syntex saw Mr. Knightstep reach the level of Director, Human Resources Programs and Administration. In this capacity, he was responsible for the development of many innovative processes in the areas of compensation, diversity, legal requirements, training and development, succession planning, communications, staffing, and systems development. He had management responsibility for twenty-four employees and a six million dollar budget.

Mr. Knightstep is committed to aligning the organization's Human Resources needs with the business needs of the organization. Only when Human Resources is integrated with the business of the organization can it bring true value to the organization, its management, its customers, and its employees. 
Name:

Education: $\quad$ BS Business Administration, University of Pittsburgh, 1980 MBA, Robert Morris College, 1985

Affiliation: Westinghouse Electric Corporation

Experience: Mrs. Marts has 17 years of diverse experience within Westinghouse Electric Corporation. As a co-leader of the restructuring of the Westinghouse Electric Corporation's Human Resource function, she and her team will have achieved a $30 \%$ cost reduction and alignment of the function with the strategic direction of the business. Her responsibilities included conceptual design and implementation leadership across seven autonomous business units.

Prior to this assignment, Mrs. Marts led the Nuclear and Advanced Technology Divisions' Total Quality and Strategic Programs organizations and reengineered a $\$ 100 \mathrm{M}$ Engineering Services business, achieving within 18 months, a $20 \%$ reduction in direct product costs. She also managed the Commercial Nuclear Quality Assurance Program, consolidating four independent programs into one business unit program resulting in a $25 \%$ cost savings while maintaining ASME, ISO 9000 and Government Compliance. She also led the development and management of the Commercial Nuclear Quality Assurance program for use within the ECC and FSU.

From 1977 to 1980 she provided support to the Past President of the IEEE, Chairman of the World Energy Conference. As a Human Resource generalist from 1981 through 1985, she served the needs of fourteen different businesses of Westinghouse and was responsible for project management of the Electric Utility Substation Engineering product line relocation, the human resource support for the closedown of motor, learning and controls businesses. In 1986, she was chartered to provide Total Quality Management and Quality Assurance Engineering support for the nuclear manufacturing business. In 1988, she assumed leadership of the employee services function within the ElectroMechanical Division. In 1991, as Total Quality and Strategic Program Manager, she assumed responsibility for leading Total Quality Management, Quality Assurance Engineering, Strategic Planning and Executive staff support efforts. 
Name:

Education: City Univ. of New York, Columbia Univ. Graduate Study

Affiliation: Workforce Solutions, an IBM Company

Experience: Michael J. Murphy is a Senior Human Resources Consultant in WFS Workforce Solutions, an IBM Company. He specializes in the reengineering of human resources services and employee relations. Mr. Murphy has over sixteen years of experience in human resource management organizations. In his current assignment, Mr. Murphy provides a full range of human resource consulting services to major IBM clients. $\mathrm{He}$ is currently working with a major telecommunications company on the redesign of their human resource services. In his previous assignment, he let a team of twenty-five professionals who provide consulting services and operations support to IBM clients across the Northeast and Midwest.

In that assignment, his team helped two major IBM organizations reduce their costs through the redeployment of nearly two thousand employees. The efforts of his team included identifying and matching IBM requirements across the U.S. to available employees with critical skills. This enabled the client to retain key people and minimize involuntary workforce reductions. When layoffs were required for the first time in IBM, Mr. Murphy personally trained over five hundred managers in methodology and renewal strategies. Client executives cited Mr. Murphy's contribution as key to the success of this difficult project.

As part of a select team, Mr. Murphy helped IBM reduce human resource costs and maintain excellent internal human resource management services. Results included the creation of WFS Workforce Solutions, an IBM Company, which now provides a blend of consulting and outsourcing services to IBM and other clients. Workforce Solutions accomplished a thirty-five percent reduction in human resources staff, maintained key services, and began external marketing all in its first year.

Because of his achievements, Mr. Murphy has been selected to receive numerous IBM awards. Outside IBM, his civic efforts have been recognized by the Mayor of Philadelphia and the New York State Chapter of Big Brothers/Big Sisters.

$$
\text { E - } 10
$$


Name: $\quad$ Jane Paradiso

Education: Bell Laboratories Engineering School

Rutgers Graduate School of Business Administration

Salamanca University

Pennsylvania State University

Affiliation: Talisman Technologies, Inc. and Talisman Services, Inc.

Experience: Ms. Paradiso is President of Talisman Technologies, a consulting company that offers strategic planning and consulting services and Talisman Services, an HR speciality software development company. Talisman clients include Fortune 200 and Financial Times 100 companies, government and military organizations and HR consulting companies.

Ms. Paradiso recently developed a strategic plan to streamline payroll, benefits, employment and placement at Florida Power \& Light. She wrote a strategic plan for British Telecom that introduced cost efficient electronic workflow systems to provide British Telecom's employees with direct access to information. She also wrote a strategic plan to radically change HR processes at Merck \& Co.

Ms. Paradiso delivered strategic planning key note speeches for executive audiences at the Department of Defense and Walt Disney. She served as technical planner and developer for a Ford Motor Company's Job Opportunity Plan, which uses voice and integrated facsimile systems.

Ms. Paradiso is a partner in two joint ventures in the United Kingdom. She worked with International Computers Limited (ICL) and an international consortium to competitively win and manage the United Kingdom lottery.

Ms. Paradiso has given presentations on re-engineering HR at various seminars: HRSP, HRMS, The Conference Board, Michigan State University and Princeton University.

Prior to founding Talisman, Ms. Paradiso held executive positions with Bell Atlantic and consulting positions with Deloitte \& Touche and Price Waterhouse. 
Name: $\quad$ Harry L. Peebles

Education: $\quad$ AB Sociology, University of Georgia, 1956

Affiliation: HLP Consultant

Experience: $\quad$ Mr. Peebles' firm, HLP CONSULTANT, provides Senior Management Consultation and Management Services to a variety of clients including: research and development laboratories; architect-engineering, facilities management and environmental services firms; and management and technical support firms.

Mr. Peebles held the position Principal Deputy Assistant Secretary for Management and Administration, United States Department of Energy. He was responsible for advising the Secretary and other appointees; for formulating policies and programs; and for managing organizations executing programs for Federal Personnel Management; Organization and Management Systems; Administrative Operations; Project, Program and Facilities Management; Contractor Industrial and Labor Relations; Telecommunications and ADP Operations; Acquisition and Management of Computing Resources and Information Systems; Equal Employment Opportunity; and Scientific and Technical Information Management. He also provided oversight to the Procurement and Acquisition Management, and the Controller and Financial Management Directorates.

During his Federal career of more than thirty years, he held key positions and played major roles in planning, coordination, and change management in organization and reorganization of Federal Energy Programs, including the Atomic Energy Commission, the Energy Research and Development Administration, and establishment of the Department of Energy.

Mr. Peebles represented the Department in testimony and budget defense to the Office of Management and Budget, and to Congressional Appropriations and Oversight Committees. He represented the Department on interagency boards, councils, and Task Forces; and to foreign governments and International Organizations. He has an Active "Q" Clearance. 
Name:

Education: $\quad$ BA Political Science, Michigan State University, 1964 Law School, Wayne State University, 1965

Affiliation: Xerox Corporation, United States Customer Operations (USCO)

Experience: With over 27 years of varied Human Resources experience, Mr. Perry is presently Manager, Human Resources Information Systems Operations and Quality within USCO. His responsibilities include Human Resources reporting, including EEO/AA, retention, manpower, and compensation and internal and external consulting on Total Quality Management. Among his current assignments is the process management of the policy deployment cascade down through all levels of the organization. This includes obtaining agreement on the enterprise level Mission, Vision, Goals, Objectives, and Measures, and ensuring that they are effectively reinforced through bonus plans and management communications.

He is currently a part of an eight member work group with a set of joint objectives focusing on development of Human Resources productivity solutions for managers and employees across the company. Some examples of these include a bonus calculator enabling employees to calculate their own bonuses using current performance data, a PC based application for employees to build their own performance management documents, and a system by which employees can input their own exception time electronically thus eliminating much paper handling and delayed payment.

Mr. Perry joined Xerox in 1965 as a Sales Representative, moved to Human Resources in 1967 and has served in a number of varied line and staff assignments since then. He was part of the team which planned the Human Resources Management portion of the campaign for the Malcolm Baldrige Award which Xerox won in 1989. After training in the Baldrige site examination skills, he conducted internal Baldrige type inspections within Xerox to ensure that all units were performing at the NQA level. 
Name:

Education: $\quad$ B.S. in Education, minor in Philosophy, Adelphi Univ., 1968 Cultural Anthropology, Oxford Univ., Oxford, England

Affiliation: Martin Marietta Astronautics

Experience: $\quad$ Ms. Carol Remington has 25 years of Human Resource experience, 15 years of management, and a dedication to continual improvement. Ms. Remington is presently the Mgr, Reward Systems for Astronautics, with 10,000 personnel. The Reward Systems role is to: (1) provide compensation oversight for multiple locations in Denver, VAFB, the Cape, San Diego and some East and West Coast offices; (2) build the framework for the salary management program: market pricing, structure analysis, job evaluation, merit budget allocations, and executive salary planning; and (3) represent Astronautics for government audits. Currently, she is exploring alternative reward initiatives.

Ms. Remington recently designed a lump sum performance increase program as an alternative to base rate increases. She has been a champion for alternatives to base rate performance increases as a method of balancing rewards for employees with the need to manage the escalating average rates.

During her 6 years of Martin employment, she has been responsible for Benefits \& Human Resource Info Systems. This enabled her to communicate the concept of total Compensation including benefits, bonuses, \& nonfinancial recognition.

She spent 13 years at Northrop Aircraft Division in management positions including Compensation, Benefits, Employee Relations, EEO, and Employee Services, all of which included training. She introduced a $401 \mathrm{~K}$ tax deferred Savings Plan; designed a data base to determine the employee complaint trends; and helped to determine a strategic direction to resolve the complaints. At one point, she had responsibility for Food Services, the Employee Store, the Recreational Clubs, and the Vanpool Program. This gave her the opportunity to manage a large organization. She chaired the Human Resources committee chartered with defining the long range approach for coping with the 1990's and beyond. 
Name:

Education: $\quad$ PhD. in Biology, University of New Mexico

Affiliation: $\quad$ Martin Marietta Energy Systems, Inc. (Energy Systems): Oak Ridge National Laboratory (ORNL)

Experience: From 1955 to 1974 Dr. Richmond served both in research and administrative functions in the Life Sciences Program at the Los Alamos Scientific Laboratory. Richmond received the E. O. Lawrence award and gold medal in 1974 for research conducted at Los Alamos.

He joined ORNL in 1974 as Associate Laboratory Director for Biomedical and Environmental Sciences and served in that position until 1990. In 1984 he also assumed responsibility for Science Education programs at ORNL. In 1990, Richmond became the Director of Science Education and External Relations at ORNL and Associate Laboratory Director Emeritus.

Richmond is responsible for ongoing university and educational programs, for the development of the ORNL Regional Science Education Center, for liaison with various educational consortia and the State of Tennessee's Department of Education, for developing science education programs between ORNL and community school systems.

Richmond is a member of the National Research Council's Mathematical Sciences Education Board, the American Technical Education Association and its National Advisory Council, the State of Tennessee Business Roundtable's Education Task Force, and a consultant to the National Education Goals Panel's Resource Group working on Goal Five (Science and Mathematics).

He is a member of the Federal Interagency Strategy Team for the Tri-State Education Initiative (AL, MS, and TN) and a member of the Regional Board of Directors for the U.S. Department of Education's Appalachia Educational Laboratory's Eisenhower Mathematics-Science Consortium in TN, KY, VA, and WV. He is a member of the Consortium for School Networking and a member of the Oak Ridge Chamber of Commerce Education Committee and cochairman of the Oak Ridge 2000 Steering Committee. 
Name:

Beth B. Sexton

Education: $\quad$ B.S. Marketing and Business Administration, Virginia Tech, 1978

Affiliation: $\quad \mathrm{CH} 2 \mathrm{M} \mathrm{HILL}$

Experience: Ms. Sexton has sixteen years experience in human resources and organizational development. She is currently Manager of Human Resources for $\mathrm{CH} 2 \mathrm{M}$ Hill operations. She manages human resources for twelve regions and a staff of thirty human resources managers and generalists. Her responsibilities include development and implementation of strategic human resource initiatives, policy development and delivery of human resource core processes.

Ms. Sexton recently was a member of the team that led CH2M Hill's regional reengineering that resulted in improved efficiency and effectiveness of regional operations through restructuring and process redesign. She also had a leadership role in reengineering human resources which resulted in further decentralization of human resource functions to align with a flatter, leaner organization. She is currently implementing CH2M Hill's performance enhancement system which she had an integral role in the design.

During her tenure with $\mathrm{CH} 2 \mathrm{M}$ Hill, Ms. Sexton has held a broad range of leadership roles in organizational development, work and family initiatives, and training. Prior to CH2M Hill, Ms. Sexton has held human resource management positions with American Petroleum Institutes, Ellerbe-Beckett and Norfolk Southern. 
Name: $\quad$ Philip Thullen

Education: B.S. with highest honors and honors in Mechanical Engineering, Purdue University, 1965

S.M. in Mechanical Engineering, MIT, 1967

Sc.D., MIT, 1969

Affiliation: Los Alamos National Laboratory (LANL), EM/RT

Experience: Dr. Thullen established Independent Technical Reviews as a Los Alamos program in June of 1991, and shortly thereafter became the Program Manager for "Red Team" Reviews. Since that time he has led and participated in over 12 ITRs and numerous spinoff activities derived from review results. Dr. Thullen's work in this field has been recognized as instrumental in introducing change at many Defense Complex sites by the past and present Assistant Secretaries for Environmental Restoration and Waste Management, and many other DOE managers.

During Dr. Thullen's career at Los Alamos (1976), he has been a staff member, Deputy Group Leader and Program Manager in energy related fields. He was a principal participant in activities that culminated in the funding of the Confinement Physics Research Facility (CPRF), the most recent major magnetic fusion experiment at Los Alamos. From 1985 to 1991 he was the Program Manager for Construction of the CPRF, an \$80M, seven year DOE Major System Acquisition employing 70 FTEs. Construction activities ranged from conventional bricks and mortar to sophisticated scientific equipment. As part of the construction activities, Dr. Thullen was instrumental in obtaining, installing and testing a 1430 MVA generator, one of the largest generators ever manufactured. This broad experience has given Dr. Thullen a depth of experience in applied research and the organization and management of R\&D facility construction.

Previous to his career at Los Alamos, from 1969 through 1976, Dr. Thullen was Assistant and Associate Professor of Mechanical Engineering at MIT. He performed research on the application of superconductors to electrical power equipment, and taught classical thermodynamics, and related subjects. He authored many fundamental papers on superconducting generator design, received three patents for major generator components, and awards for technical paper excellence. 
Name: Ieri L. Trevisani

Education:

Affiliation: Martin Marietta Corporation

Experience: 
Name:

Douglas L. Weaver

Education: $\quad$ BSET, DeVry Technical Institute, 1966

Affiliation: Sandia National Laboratories (SNL)

Experience: Mr. Weaver has twenty-four years experience in management and operation of complex manufacturing facilities. Mr. Weaver is presently applying this experience to support a DOE Environmental Restoration and Waste Management Program need for independent technical reviews (Red Teams) of programs and projects. His responsibilities include preparing, managing, performing, and reporting Red Team reviews.

Mr. Weaver recently led the DOE Office of Facility Transition, EM-60, Red Team chartered to recommend a new, integrated path forward for the Rocky Flats Plant. He led a similar Red Team review of the Oak Ridge National Laboratory Isotopes Facilities Shutdown Program. The comprehensive assessment and recommendations of both review teams were endorsed by DOE EM-60 and adopted by the DOE field offices. He played a key role in Red Team reviews of the Hanford Waste Vitrification Plant, the Savannah River Defense Waste Processing Facility, the Hanford tank waste operations, and the Hanford PUREX deactivation project. He also provides planning, management, and operations consulting support to EM-60, DP-20, and several DOE field and area offices.

During his twenty-seven year employment by Sandia National Laboratories, Mr. Weaver has held a number of management positions. From 1984 to 1986 he managed the Radiation Hardened Integrated Circuit Development Division. In this capacity he was responsible for developing the microelectronics technology and process clean room, and facility concepts for a 176,000 sq. ft., \$67M microchip manufacturing facility. Most recently he managed the Microelectronics Component Development program, including technology and process development, conduct-ofoperations and maintenance, statutory compliance, manufacturing, DoD and industrial microchip development projects, and advanced microelectronics packaging development. He has been responsible for the activities of over 100 Ph.D., M.S., and B.S. engineers, technicians, and hourly personnel with an annual budget of $\$ 15 \mathrm{M}$. 
THIS PAGE

\section{LEFT BLANK}

INTENTIONALLY 


\section{APPENDIX F}

\section{LIST OF ACRONYMS}

$\begin{array}{ll}\text { AA } & \text { Affirmative Action } \\ \text { AEC } & \text { Atomic Energy Commission } \\ \text { AOO } & \text { Albuquerque Operations Office } \\ \text { CAPRS } & \text { Compensation and Performance Review Systems } \\ \text { CIO } & \text { Chief Information Officer } \\ \text { COBRA } & \text { Consolidated Omnibus Budget Reconciliation Act } \\ \text { COO } & \text { Chief Operations Officer } \\ \text { DOD } & \text { Department of Defense } \\ \text { DOE } & \text { Department of Energy } \\ \text { EEO } & \text { Equal Employment Opportunity } \\ \text { ES\&H } & \text { Environment, Safety and Health } \\ \text { FTE } & \text { Full-time Equivalent } \\ \text { GEP } & \text { Graduate Education Programs } \\ \text { HQ } & \text { Headquarters } \\ \text { HR } & \text { Human Resources } \\ \text { HRM } & \text { Human Resources Management } \\ \text { HRIS } & \text { Human Resources Information System } \\ \text { IS } & \text { Information Systems } \\ \text { ITR } & \text { Independent Technical Review } \\ \text { JEG } & \text { Job Evaluation Guidelines } \\ \text { JIT } & \text { Just in Time } \\ \text { KAO } & \text { Kirtland Area Office } \\ \text { LANL } & \text { Los Alamos National Laboratory } \\ \text { LPR } & \text { Laboratory Process Reengineering } \\ \text { M\&O } & \text { Management and Operations } \\ \text { MIS } & \text { Management Information Services } \\ \text { MMC } & \text { Martin Marietta Corporation } \\ \text { NM } & \text { New Mexico } \\ \text { OE/OD } & \text { Organizational Effectiveness/Organizational Development } \\ \text { O\&IE } & \text { Organization and Individual Effectiveness } \\ \text { PMP } & \text { Performance Management Process } \\ \text { R\&D } & \text { Research and Development } \\ \text { ROI } & \text { Return on Investment } \\ \text { SCAID } & \text { Science Advisor } \\ \text { SHRP } & \text { Strategic Human Resources Plan } \\ \text { SNL } & \text { Sandia National Laboratories } \\ \text { SQLC } & \text { Sandia Quality Leadership Council } \\ \text { UCAI } & \text { Unclassified Controlled Access Information } \\ \text { WFS } & \text { Work Force Solutions } \\ \text { WST } & \text { Work Study Trainee Program } \\ \text { YOT } & \text { Youth Opportunity Trainee Program } \\ & \end{array}$

$$
\text { F - } 1
$$

PREDECISONAL DRAFT, REV. 1 
THIS PAGE

\section{LEFT BLANK}

INTENTIONALLY

PREDECISONAL DRAFT, REV. 1 
DISTRIBUTION:

1 Boyle \& Associates

Attn: J. Boyle

2502 Rocky Point Drive

Suite 350

Tampa, FL 33607

1 IBM

Attn: J. Brown

Route 9

Town of Mt. Pleasant

N. Tarrytown, NY 10591

1 Battelle

Attn: W. Brown

3180 10th Street

Richland, WA 99352

1 Honeywell, Inc.

Attn: L. Crowe

9201 San Mateo NE

Alb., NM 87113-2227

1 ORISE

Attn: J. Doggette

TMSD

230 Warehouse Road

Oak Ridge, TN 37831

1 Knightstep Consulting

Attn: C. Knightstep

1010 West Fremont Ave.,

Suite B-2

Sunnyvale, CA 94087

1 Westinghouse Electric Corp.

Attn: T. Marts

11 Stanwix Street

Room 1404

Pittsburgh, PA 15222

1 IBM Workforce Solutions

Attn: M. Murphy

522 South Road MS P909

Poughkeepsie, NY 12601-5400
1 Talisman Technologies, Inc.

Attn: J. Paradiso

P. O. Box 10504

McLean, VA 22102

1 HLP Consultant

Attn: H. Peebles

6011 Executive Blvd.

Suite 200

Rockville, MD 20850

1 Xerox Corporation

Attn: R. Perry

100 Clinton Ave., South-03A

Rochester, NY 14464

1 Martin Marietta Astronautics

Attn: C. Remington

Mail Stop DC 1325

12999 Deercreek Canyon Road

Littleton, CO 80127-5146

1 ORNL/MMES

Attn: C. Richmond

105 Mitchell

MS 6496

Oak Ridge, TN 37831-6496

1 CH2M HILL

Attn: B. Sexton

115 Perimeter Center Place NE

Suite 700

Atlanta, GA 30346-1278

2 LANL

Attn: P. Thullen, MS K-570

TA-52, Bldg. 1, Room 202

Los Alamos, NM 87545

1 Martin Marietta Corporation Attn: J. Trevisani 230 Mall Blvd., M - 3222 King of Prussia, PA 19406 
Distribution (cont.):

1 MS 0101 A. Narath, 1

1 MS 0102 J. Tegnelia, 2

1 MS 0260 A. Westwood, 1000

1 MS 0337 A. Romig, 1800

1 MS 0513 H. Schmitt, 2000

1 MS 0513 W. Bechdel, 2000

1 MS 0511 G. Beeler, 2500

1 MS 0186 C. Emery, 3000

1 MS 1025 J. Sanchez, 3010

1 MS 1351 W. Dawes, 3020

1 MS 0343 K. Eckelmeyer, 3020

1 MS 1351 T. Schultheis, 3020

1 MS 1351 J. Lovato, 3020

1 MS 1301 J. Romero, 3030

1 MS 1017 L. Clevenger, 3300

1 MS $1017 \mathrm{H}$. Morgan, 3300

1 MS 1017 E. Dunckel, 3331

1 MS 1019 L. Clevenger, 3332

1 MS 1018 D. Reed, 3333

1 MS 1015 L. Duffy, 3335

1 MS 1029 R. Bonner, 3500

1 MS 1026 D. Brown, 3511

1 MS 1012 E. Saucier, 3512

1 MS 0653 S. Barnes, 3522

1 MS 0653 B. Holley, 3525

1 MS 0653 C. Seyfer, 3525

1 MS 1023 M. Torneby, 3531

1 MS 1023 R. McClaflin, 3533

1 MS $1005 \mathrm{~J}$. Henderson, 3538

1 MS 1022 B. Jones, 3543

1 MS 1021 C. Griego, 3544

1 MS 0187 E. Cassidy, 3545

1 MS 1088 A. Thornton, 3600

1 MS 1088 R. Fairbanks, 3610

1 MS 1087 L. Vigil-Lopez, 3611

1 MS 1087 B. Learson, 3612

1 MS 0149 P. Robinson, 4000

1 MS $0131 \mathrm{~J}$. Weiss, 4500

1 MS 0463 R. Hagengruber, 5000

1 MS 0461 C. Yarnall, 5500

1 MS 0724 D. Hartley, 6000

1 MS 0726 J. Woodard, 6600

1 MS 0725 T. Hunter, 6900

1 MS 1067 L. Jones, 7000
1 MS 0850 N. Hartwigsen, 7900

1 MS 9001 J. Crawford, 8000

1 MS 9037 R. Detry, 8200

1 MS 9002 P. Smith, 8500

1 MS 0151 G. Yonas, 9000

1 MS 0766 J. Kelsey, 9600

1 MS 0112 P. Stanford, 10000

1 MS 0109 G. Riser, 10000D

1 MS 0109 M. Ebben, 10600

1 MS 0141 M. Kestenbaum, 11000

1 MS 0141 H. Folley, 11100

1 MS 12100 V. Dugan, 12100

1 MS 0631 D. Schwoebel, 12300

1 MS 1375 L. Bertholf, 12400

1 MS $0131 \mathrm{~J}$. Langhelm, 12600

1 MS 1369 C. Tapp, 12900

1 MS 1369 K. Pound, 12900

1 MS 0630 M. Eaton, 13100

1 MS 0803 J. Jones, 13200

30 MS 1003 D. Weaver, 6604

30 MS 0111 S. Wallace, 10605

1 MS 9018 CTF, 8523-2

5 MS 0899 Tech. Lib., 13414

1 MS 0619 Tech. Pub., 13416

10 MS 0100 Doc. Proc., 7613-2

For DOE/OSTI 